\title{
FINAL

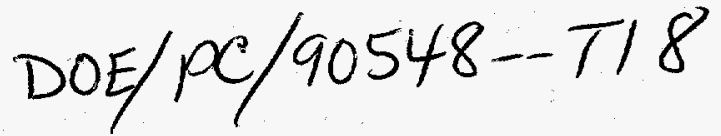

LIFAC DEMONSTRATION

AT

RICHMOND POWER AND LIGHT

WHITEWATER VALLEY UNIT No. 2

FINAL REPORT VOLUME 1: PUBLIC DESIGN

Sponsored by:

U.S. Department of Energy

LIFAC North America

Richmond Power and Light

State of Indiana

Electric Power Research Institute

Black Beauty Coal Company

Cooperative Agreement No. DE-FC22-90PC90548

February 1998

Submitted by:

RECEIVED

LIFAC North America

Fairfax, Virginia

MAR 16 1098

OSTI

Prepared by: DISTRISUTION OF THS DOCUMENI IS UNLIMITED.

ICF Kaiser Engineers

Pittsburgh, Pennsylvania

Tampella Power Corp.

Marietta, Georgia

"Cleared by DOE Patent Counsel on May 7, 1997" 


\section{DISCLAIMER}

This report was prepared as an account of work sponsored by an agency of the United States Government. Neither the United States Government nor any agency thereof, nor any of their employees, makes any warranty, express or implied, or assumes any legal liability or responsibility for the accuracy, completeness, or usefulness of any information, apparatus, product, or process disclosed, or represents that its use would not infringe privately owned rights. Reference herein to any specific commercial product, process, or service by trade name, trademark, manufac. turer, or otherwise does not necessarily constitute or imply its endorsement, recommendation, or favoring by the United States Government or any agency thereof. The views and opinions of authors expressed herein do not necessarily state or reflect those of the United States Government or any agency thereof. 


\section{DISCLAIMER}

Portions of this document may be illegible electronic image products. Images are produced from the best available original document. 


\section{DISCLAIMER}

This report was prepared by LIFAC North America pursuant to a Cooperative Agreement partially funded by the U.S. Department of Energy, and neither LIFAC North America nor any of its subcontractors nor the U.S. Department of Energy, nor any person acting on behalf of either:

A. Makes any warranty or representation, express or implied, with respect to the accuracy, completeness, or usefulness of the information contained in this report or that the use of any information, apparatus, method, or process disclosed in this report may not infringe privately-owned rights; or

B. Assumes any liabilities with respect to the use of, or for damages resulting from the use of, any information, apparatus, method or process disclosed in this report.

Reference herein to any specific commercial product, process, or service by trade name, trademark, manufacturer, or otherwise, does not necessarily constitute or imply its endorsement, recommendation, or favoring by the U.S. Department of Energy. The views and opinions of authors expressed herein do not necessarily state those of the U.S. Department of Energy. 
This report discusses the demonstration of LIFAC sorbent injection technology at Richmond Power and Light's (RP\&L) Whitewater Valley Unit No. 2 under the auspices of the U.S. Department of Energy's (DOE) Clean Coal Technology Program. LIFAC is a sorbent injection technology capable of removing 75 to 85 percent of a power plant's $\mathrm{SO}_{2}$ emissions using limestone at calcium to sulfur molar ratios of between 2 and 2.5. The site of the demonstration is a coal-fired electric utility power plant located in Richmond, Indiana. The project is being conducted by LIFAC North America (LIFAC NA), a joint venture partnership of Tampella Power Corporation and ICF Kaiser Engineers, in cooperation with DOE, RP\&L, and several other organizations including the Electric Power Research Institute (EPRI), the State of Indiana, and Black Beauty Coal Company. The purpose of Final Report Volume 1: Public Design is to consolidate, for public use, all design and cost information regarding the LIFAC Desulfurization Facility at the completion of construction and startup. This report has been prepared pursuant to Cooperative Agreement No. DE-FC22-90PC90548 between LIFAC NA and the U.S. Department of Energy. 


\section{POINT OF CONTACT}

The following persons should be contacted for further information regarding the LIFAC desulfurization demonstration project and/or the sorbent injection technology being used:

- James D. Hervol •

ICF Kaiser Engineers

Gateway View Plaza

1600 W. Carson St.

Pittsburgh, Pennsylvania 15219

(412) 497-2235

- James G. Patel •

Tampella Power Corp.

2300 Windy Ridge Parkway

Atlanta, Georgia 30067

Phone (404) 859-2621

- Juhani Viiala •

Tampella Power Inc.

Lapintie 1

22100 Tampere

Finland

Phone 358-31-2413111

- Daniel Stoup •

ICF Kaiser Engineers

Gateway View Plaza

1600 W. Carson St.

Pittsburgh, Pennsylvania 15219

(412) 497-2231

- Christopher Keating •

ICF Kaiser Engineers

Gateway View Plaza

1600 W. Carson St.

Pittsburgh, Pennsylvania 15219

(412) 497-2233 
Section

$\underline{\text { Page }}$

0.0 EXECUTIVE SUMMARY

$1.0 \quad$ PROJECT OVERVIEW $\ldots \ldots \ldots \ldots \ldots \ldots \ldots \ldots \ldots \ldots \ldots \ldots \ldots \ldots \ldots$

$1.1 \quad$ Purpose of the Public Design Report $\ldots \ldots \ldots \ldots \ldots \ldots \ldots \ldots \ldots \ldots$

1.2 Brief Description of the Project $\ldots \ldots \ldots \ldots \ldots \ldots \ldots \ldots \ldots \ldots \ldots \ldots \ldots \ldots \ldots$

1.2.1 Project History $\ldots \ldots \ldots \ldots \ldots \ldots \ldots \ldots \ldots \ldots \ldots \ldots \ldots \ldots \ldots$

1.2.2 Project Organization $\ldots \ldots \ldots \ldots \ldots \ldots \ldots \ldots \ldots \ldots \ldots$

1.2 .3 Host Site $\ldots \ldots \ldots \ldots \ldots \ldots \ldots \ldots \ldots \ldots \ldots \ldots \ldots$

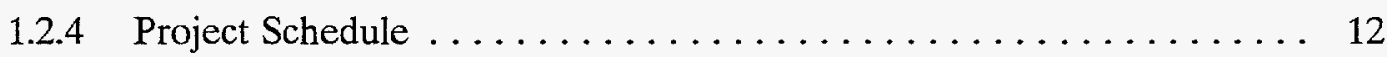

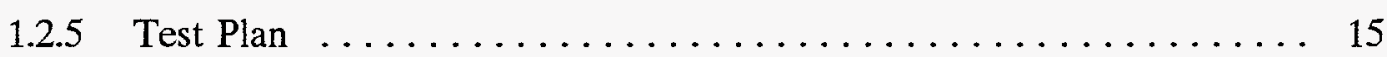

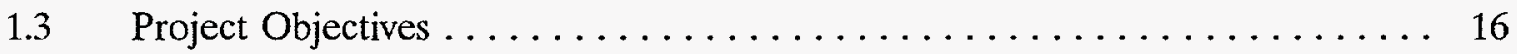

1.4 Significance of the Project Commercialization and Process Advantages . . . . . 16

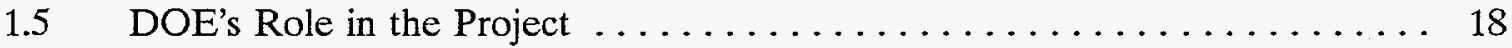

2.0 TECHNOLOGY DESCRIPTION $\ldots \ldots \ldots \ldots \ldots \ldots \ldots \ldots \ldots \ldots \ldots$

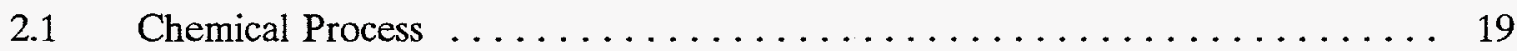

$3.0 \quad$ PROCESS DESIGN CRITERIA $\ldots \ldots \ldots \ldots \ldots \ldots \ldots \ldots \ldots \ldots \ldots \ldots \ldots \ldots$

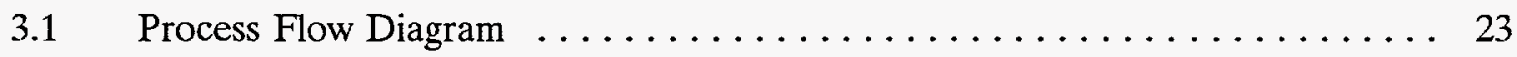

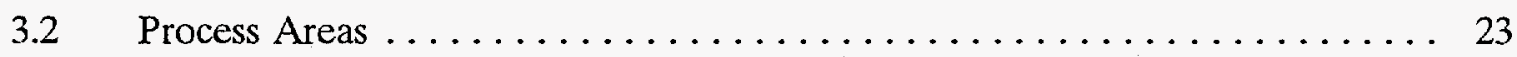

3.2.1 Limestone Storage and Handling Area $\ldots \ldots \ldots \ldots \ldots \ldots \ldots$

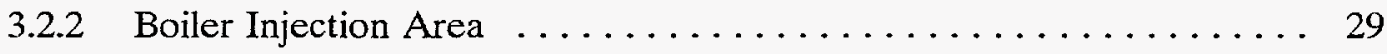

3.2.3 Activation Reactor Area .................... 31

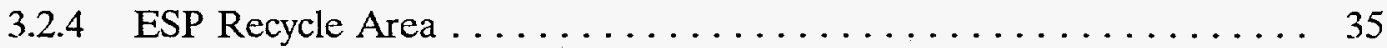

3.2.5 Process Monitoring and Control $\ldots \ldots \ldots \ldots \ldots \ldots \ldots \ldots$

3.3 Host Site Modifications $\ldots \ldots \ldots \ldots \ldots \ldots \ldots \ldots \ldots \ldots \ldots \ldots \ldots \ldots \ldots \ldots \ldots \ldots \ldots$

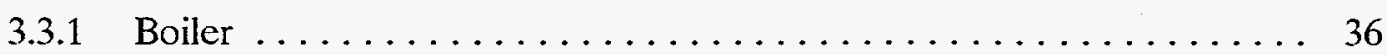

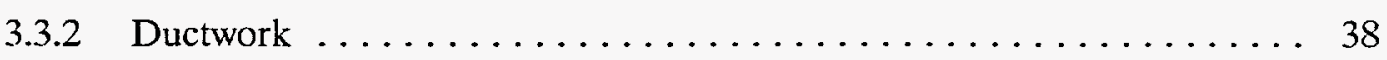

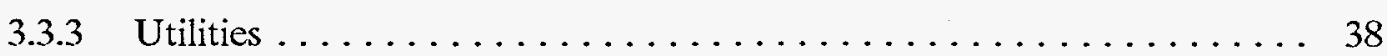

3.3.4 Electrical and Control Systems $\ldots \ldots \ldots \ldots \ldots \ldots \ldots \ldots \ldots$ 
$4.0 \quad$ DETAILED PROCESS DESIGN $\ldots \ldots \ldots \ldots \ldots \ldots \ldots \ldots \ldots \ldots \ldots$

4.1 Plot Plan and Plant Layout $\ldots \ldots \ldots \ldots \ldots \ldots \ldots \ldots \ldots \ldots \ldots \ldots$

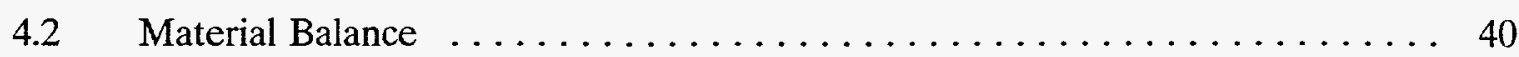

4.3 Process and Instrumentation Diagrams $\ldots \ldots \ldots \ldots \ldots \ldots \ldots \ldots \ldots$

4.4 Process Equipment Arrangement $\ldots \ldots \ldots \ldots \ldots \ldots \ldots \ldots \ldots \ldots$

$4.5 \quad$ Waste Streams and Their Disposal $\ldots \ldots \ldots \ldots \ldots \ldots \ldots \ldots \ldots \ldots$

$5.0 \quad$ PROJECT CAPITAL $\ldots \ldots \ldots \ldots \ldots \ldots \ldots \ldots \ldots \ldots \ldots \ldots \ldots \ldots \ldots$

$6.0 \quad$ PROCESS OPERATING COST $\ldots \ldots \ldots \ldots \ldots \ldots \ldots \ldots \ldots \ldots \ldots$

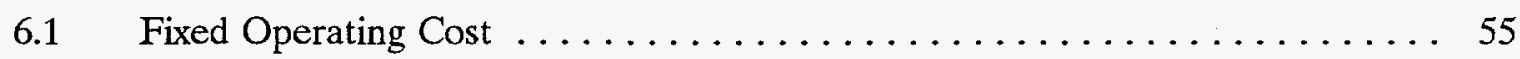

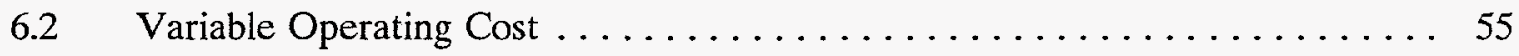

$6.3 \quad$ Startup and Checkout Cost $\ldots \ldots \ldots \ldots \ldots \ldots \ldots \ldots \ldots \ldots$

$7.0 \quad$ COMMERCIAL APPLICATIONS $\ldots \ldots \ldots \ldots \ldots \ldots \ldots \ldots \ldots \ldots \ldots \ldots \ldots$

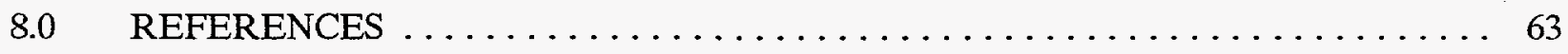

\section{APPENDICES}

Appendix I Coal Analysis

Appendix II Limestone Analysis 


\section{LIST OF FIGURES}

$\underline{\text { Figure }}$

$\underline{\text { Page }}$

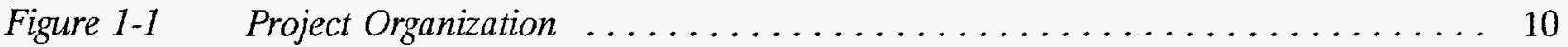

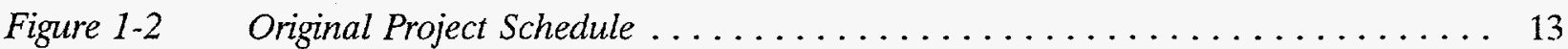

Figure 1-3 Current Project Schedule (Revised June 1993) . . . . . . . . . . . 14

Figure $2-1 \quad$ LIFAC Overall Block Flow Diagram $\ldots \ldots \ldots \ldots \ldots \ldots \ldots \ldots \ldots \ldots$

Figure 3-3 LIFAC Desulfurization Process Flow Diagram ............... 25

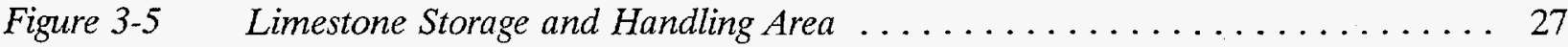

Figure $3-6 \quad$ Boiler Injection Area $\ldots \ldots \ldots \ldots \ldots \ldots \ldots \ldots \ldots \ldots \ldots \ldots \ldots \ldots \ldots \ldots \ldots \ldots$

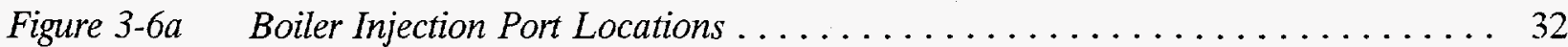

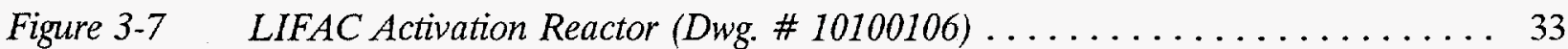

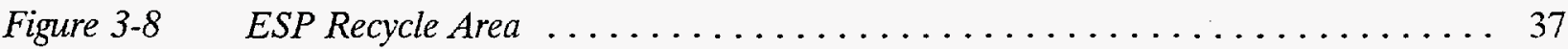

Figure $4-1 \quad$ Site Plan at Richmond Power and Light $\ldots \ldots \ldots \ldots \ldots \ldots \ldots \ldots \ldots$

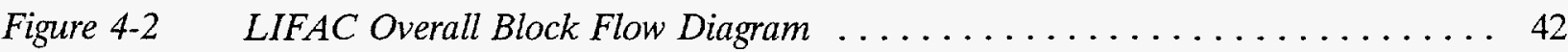

Figure 4-3 Process and Instrumentation Diagram (1 of 2$) \ldots \ldots \ldots \ldots \ldots \ldots$

Figure 4-4 Process and Instrumentation Diagram $(2$ of 2$) \ldots \ldots \ldots \ldots \ldots$

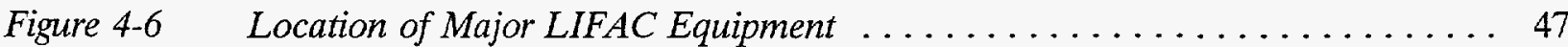




\section{LIST OF TABLES}

$\underline{\text { Table }}$

$\underline{\text { Page }}$

Table $3 A \quad$ Process Values Used for Preliminary Design Calculations . . . . . . . . . . 22

Table $3 B \quad$ Normal LIFAC Flow Values at High and Low Boiler Loads . . . . . . . ..... 24

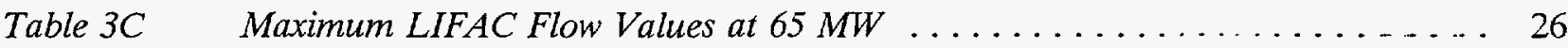

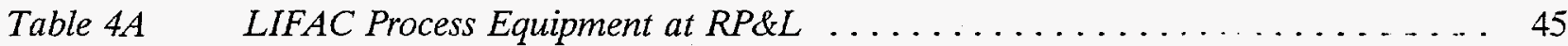

Table 5A Capital Cost of the Richmond LIFAC Unit as Installed (Base Y.2 1993) _.... 50

Table 5B Procurement Cost and Budgets - Equipment, Materials and Subc:racts -

Budget Period II Commitments . . . . . . . . . . . . . . . . . . 51

Table 5C Estimated Costs for Existing Equipment Incorporated into the LE $= \pm C$ Projem _. . 54

Table 6A Estimated Annual Fixed Operating Cost Under Continuous Oper:zion ....... . 56

Table $6 B \quad$ Estimated Variable Operating Cost During Normal Conditions . . . . . . . . . 57

Table $6 C . \quad$ Estimated Startup Cost of the LIFAC System . . . . . . . . . . . . . . . . 59

Table $7 A \quad$ LIFAC Installations Worldwide $\ldots \ldots \ldots \ldots \ldots \ldots \ldots \ldots \ldots \ldots \ldots \ldots$ 


\section{LIST OF ABBREVIATIONS, ACRONYMS, AND TERMS}

\begin{tabular}{|c|c|}
\hline $\mathrm{CaCO}_{3}$ & Calcium carbonate \\
\hline $\mathrm{CaO}$ & Calcium oxide \\
\hline $\mathrm{CaSO}_{3}$ & Calcium sulfite \\
\hline $\mathrm{CaSO}_{4}$ & Calcium sulfate \\
\hline $\mathrm{Ca}(\mathrm{OH})_{2}$ & Calcium hydroxide, hydrated lime \\
\hline $\mathrm{Ca} / \mathrm{S}$ & $\begin{array}{l}\text { Calcium/sulfur molar ratio, (moles of } \mathrm{Ca} \text { in sorbent/moles of } \mathrm{S} \text { in inlet flue gas } \\
\text { stream) }\end{array}$ \\
\hline $\mathrm{CCT}$ & Clean Coal Technology \\
\hline DOE & U.S. Department of Energy \\
\hline EER & Energy and Environmental Research Corporation \\
\hline EPRI & Electric Power Research Institute \\
\hline ESP & Electrostatic precipitator \\
\hline FGD & Flue gas desulfurization \\
\hline ICF Kaiser & ICF Kaiser Engineers, Inc. \\
\hline ID fan & Induced draft fan \\
\hline LIFAC & $\begin{array}{l}\text { Limestone Injection into the Furnace with Activation of unreacted Calcium } \\
\text { oxide, registered trademark of Tampella desulfurization process }\end{array}$ \\
\hline LIFAC NA & LIFAC - North America (partnership) \\
\hline LIMB & $\begin{array}{l}\text { Lime Injection to Multistage Burner (registered trademark of EPA } \\
\text { desulfurization process) }\end{array}$ \\
\hline LNCFS & Low- $\mathrm{NO}_{\mathrm{x}}$ Concentric Firing System \\
\hline $\mathrm{MgCO}_{3}$ & Magnesium carbonate \\
\hline MW & Megawatt \\
\hline NO & Nitric oxide \\
\hline $\mathrm{NO}_{\mathrm{x}}$ & Nitrogen oxides \\
\hline $\mathrm{O}_{2}$ & Oxygen \\
\hline PLC & Programmable logic controller \\
\hline PMS & Process monitoring system \\
\hline RP\&L & Richmond Power \& Light \\
\hline $\mathrm{SCA}$ & Specific collection area \\
\hline $\mathrm{SO}_{2}$ & Sulfur dioxide \\
\hline $\mathrm{SO}_{3}$ & Sulfur trioxide \\
\hline
\end{tabular}



temperature (approach to saturation)

USEPA U.S. Environmental Protection Agency

Injection Pulverized limestone injection into the furnace through several injection nozzles at the furnace walls

Activation Activation of the remaining $\mathrm{CaO}$ particles with water for further sulfur dioxide capture

Recycling Recycling of ash and sorbent from ESP hoppers to the reactor inlet ductwork. 
The Clean Coal Technology Program (CCT) has been recognized in the National Energy Strategy as a major initiative whereby coal will be able to reach its full potential as a source of energy for the nation and the international marketplace. Attainment of this goal depends upon the development of highly efficient, environmentally sound, competitive coal utilization technologies responsive to diverse energy markets and varied consumer needs. The CCT Program is an effort jointly funded by government and industry whereby the most promising advanced coal-based technologies are being moved into the marketplace through demonstration. The CCT Program is being implemented through a total of five competitive solicitations.

LIFAC North America, a joint venture partnership of ICF Kaiser Engineers, Inc. and Tampella Power Corporation, recently completed the demonstration of the LIFAC flue gas desulfurization (FGD) technology developed by Tampella Power. This technology provides sulfur dioxide $\left(\mathrm{SO}_{2}\right)$ emission control for power plants, especially in existing facilities with tight space limitations. $\mathrm{SO}_{2}$ emissions are expected to be reduced by up to $85 \%$ by using limestone as a sorbent. The LIFAC technology was demonstrated at Whitewater Valley Unit No. 2, a 60-MWe coal-fired power plant owned and operated by Richmond Power and Light (RP\&L) and located in Richmond, Indiana. The Whitewater plant consumes high-sulfur coals, with sulfur contents ranging from $2.0-2.9 \%$.

The project, co-funded by LIFAC North America and DOE, was conducted with the participation of RP\&L, the State of Indiana, the Electric Power Research Institute (EPRI), and the Black Beauty Coal Company. The project has a total cost of $\$ 21.4$ million and a duration of 48 months from the preliminary design phase through the testing program.

The sponsors of this project believed that LIFAC had the potential to be a new and important $\mathrm{SO}_{2}$ control option for U.S. utilities subject to the Clean Air Act's acid rain regulations. To be considered as a commercially feasible option in this particular emissions control market, LIFAC must demonstrate a high $\mathrm{SO}_{2}$ removal rate while remaining competitive with other options on a cost per ton of $\mathrm{SO}_{2}$ removed basis.

The LIFAC system combines conventional limestone injection into the upper furnace region with a post-furnace humidification reactor located between the air preheater and the electrostatic 
precipitator (ESP). The process produces a dry, stable waste product that is removed from both the bottom of the humidification reactor and the ESP.

Finely pulverized limestone ( $80 \%<325$ mesh) is pneumatically conveyed and injected into the upper region of the boiler where temperatures are approximately 1,800 to $2,200^{\circ}$ Fahrenheit. At these temperatures the limestone $\left(\mathrm{CaCO}_{3}\right)$ thermally decomposes to form calcium oxide $(\mathrm{CaO})$. As the $\mathrm{CaO}$ passes through the furnace, initial desulfurization reactions occur. A portion of the sulfur dioxide $\left(\mathrm{SO}_{2}\right)$ reacts with the $\mathrm{CaO}$ to form calcium sulfite $\left(\mathrm{CaSO}_{3}\right)$ which oxidizes to calcium sulfate $\left(\mathrm{CaSO}_{4}\right)$. Essentially all of the sulfur trioxide $\left(\mathrm{SO}_{3}\right)$ reacts with $\mathrm{CaO}$ to form $\mathrm{CaSO}_{4}$.

At an overall $\mathrm{SO}_{2}$ removal efficiency of $75 \%$, approximately $25 \%$ of the $\mathrm{SO}_{2}$ is removed in the boiler, with an additional 50\% removed after the unreacted lime has passed through the vertical elongation of ductwork known as the LIFAC activation reactor. There the flue gas is sprayed with atomized water that allows the unreacted lime to hydrate to $\mathrm{Ca}(\mathrm{OH})_{2}$ which more readily reacts with $\mathrm{SO}_{2}$ and forms $\mathrm{CaSO}_{3}$. A combination of the proper water droplet size and residence time allows for effective hydration of the lime and complete water evaporation to create a dry reactor bottom product.

After exiting the humidification reactor, the flue gas is reheated before entering the ESP. Forty \% of the LIFAC-produced spent sorbent and fly ash is collected in the humidification reactor with the remaining 59.9\% collected by the ESP. The LIFAC system can be designed so that both the reactor and ESP ash may be recycled to a point ahead of the reactor to improve sorbent utilization and to improve $\mathrm{SO}_{2}$ removal efficiency to the range of 75 to $85 \%$.

LIFAC is similar to other current sorbent injection technologies but has unique advantages with its use of a patented vertical humidification reactor. While LIFAC's $\mathrm{SO}_{2}$ removal efficiency is not as high as traditional wet FGD systems, its cost and simplicity of design, construction and operation offer other advantages over alternative systems. In particular the advantages of the LIFAC system are:

- High $\mathrm{SO}_{2}$ removal rates - Currently available sorbent injection systems have been unable to sustain high $\mathrm{SO}_{2}$ removal rates with any consistency. LIFAC has proven in the past and is demonstrating during this project the ability to achieve and sustain high $\mathrm{SO}_{2}$ removal rates of 75 to $85 \%$ over long operating periods. 
- Dry by-products - Wet lime and limestone scrubbing systems create a wet by-product ash that must be further treated before disposal. LIFAC produces a dry solid waste ash containing calcium sulfite, calcium sulfate and fly ash. This waste is easily disposed of under U.S. regulatory requirements, may be recycled to increase LIFAC's efficiency, and may have commercial applications in the construction material industry.

- Compatibility and adaptability - LIFAC has minimal impact on the host's site and systems, primarily the boiler, ESP and induced draft (ID) fan. In addition, LIFAC requires little space and few utilities and, therefore, is easily installed even in small or cramped power plant sites.

Construction of the LIFAC system has occurred in two phases over a period of one and a half years. The first phase of construction was completed during a routine plant outage in March 1991 . This period was utilized to install tie-ins to the host site's existing systems.

Ductwork and three dampers were installed between the air preheater and ESP to allow flue gas flow to the LIFAC activation reactor. Tie-ins were also made to the power plant's steam, condensate and river-water supplies. Medium-pressure steam is used to reheat the flue gas exiting the LIFAC reactor, and water is used for flue gas humidification inside the reactor. Injection ports were installed in the boiler walls about 10 feet above the nose elevation.

The second phase of construction began in the fall of 1991 with the driving of piles for the reactor and the installation of underground conduit runs. Work continued through to the summer of 1992 , with no need for plant downtime other than normally scheduled outages. During this time, the limestone storage area was completed, and the injection system was installed on Unit No. 2. The activation reactor was constructed and tested with both cold air, during a scheduled Unit No. 2 outage, and hot flue gas during a low electricity demand period. Other power plant tie-ins, such as the steam and condensate system, were also tested during low demand periods in the evenings or on weekends.

All of the construction work associated with the LIFAC system was performed in close proximity to the exterior of the power plant or in cramped areas inside the plant. The ductwork tie-ins and new steel work required inside the plant are located in small, difficult-to-access work areas. The reactor structure is approximately ten feet from the power plant with the outside ductwork and piping 
crossing over offices and the plant maintenance area. All of these new structures and equipment were constructed with no interference to daily plant operations.

The schedule for the LIFAC demonstration program extended over a four-year period from the beginning of preliminary design in August 1990 through the testing program completed in early August 1994. The LIFAC system was originally scheduled to come on-line in June of 1992, but due to delays in receiving construction permits and some minor startup problems, this date was moved to March 1993. Testing was then scheduled to continue through the summer of 1994.

The test plan for the LIFAC demonstration is composed of five distinct phases, each with its own objective. The first of these phases consists of the initial baseline testing portion of the project. Measurements were taken to characterize the operation of the host's boiler and associated subsystems prior to the use of the LIFAC system. The results were used for comparison purposes with the LIFAC system in operation and with data collected at the end of the project to determine any changes in the host's systems.

The second, or parametric, phase of testing was performed to determine the best combination of LIFAC process variables for $\mathrm{SO}_{2}$ removal. The variables studied included the limestone injection nozzles' angle and location, the $\mathrm{Ca} / \mathrm{S}$ molar ratio, the need for supplemental injection air at the boiler, the water droplet size and injection nozzle arrangement in the reactor, the ash recycling ratio, and the approach to saturation temperature of the flue gas exiting the activation reactor. The best combination of these variables was chosen at the conclusion of this phase and used for the remainder of the test program.

Parametric tests were also conducted to examine the effects of different coal and limestone feeds on the $\mathrm{SO}_{2}$ capture rate. Coals with sulfur contents as high as $3.3 \%$ were tested to determine LIFAC's compatibility with high sulfur U.S. coals. Limestones of different sizes were also tested to determine the LIFAC system's adaptability to local sorbent sources.

Optimization and long-term testing were also performed to demonstrate LIFAC's performance under commercial conditions. The LIFAC system was in operation 24 hours per day for several weeks using the power plant's baseline coal, high calcium limestone, and the optimum combination of process variables. In addition to process performance measurements, during this phase the operation and maintenance requirements of the system were examined. Long-term (two to three weeks) tests were 
also conducted with two other coals; one lower sulfur coal (1.5\%) and one higher sulfur content coal $(3.3 \%)$.

The final phase of testing was the post-LIFAC tests. The baseline tests were repeated to gather information on the condition of the boiler and its associated subsystems. Comparisons were made to the original baseline data to identify any changes either caused by the LIFAC system or independent of its operation.

It has also been shown at RP\&L and other LIFAC installations that the system can be installed without affecting normal power plant operations. The demonstration showed that the system can economically reduce $\mathrm{SO}_{2}$ emission when compared with other FGD technologies. 


\subsection{PROJECT OVERVIEW}

\subsection{Purpose of the Public Design Report}

The purpose of this Public Design Report is to provide design criteria and cost information on the LIFAC desulfurization process at the completion of construction and startup. The report serves as a reference for the demonstration technology and its future commercialization. Final Report Volume 1: Public Design has been prepared pursuant to Cooperative Agreement No. DE-FC222-90PC90548 between LIFAC North America (LIFAC NA) and the U.S. Department of Energy (DOE) titled "LIFAC Demonstration at Richmond Power and Light (RP\&L) Whitewater Valley Unit No. 2."

\subsection{Brief Description of the Project}

\subsubsection{Project History}

In 1983, Finland enacted acid rain legislation which applied limits on $\mathrm{SO}_{2}$ emissions sufficient to require that flue gas desulfurization (FGD) systems have the capability to remove about $80 \%$ of the $\mathrm{SO}_{2}$ in the flue gas. This level could be met by conventional wet limestone scrubbers but not by then available sorbent injection technology. Tampella, therefore, began developing an alternative sorbent injection system which resulted in the LIFAC process.

In 1986, the first full scale test was performed at Imatran Voima's Inkoo power plant using a 70 megawatt (MW) side-stream from a $250 \mathrm{MW}$ boiler. A $76 \% \mathrm{SO}_{2}$ removal rate with $1.5 \%$ sulfur coal was reached. A second LIFAC activation reactor was constructed to handle an additional $125 \mathrm{MW}$ side-stream. This newer reactor is achieving removal rates of 75 to $80 \%$ while using $\mathrm{Ca} / \mathrm{S}$ molar ratios of between 2 and 2.5 to 1 . Also in 1988, the first tests with high sulfur U.S. coals were run at the Neste Kullo Laboratory. A Pittsburgh No. 8 Seam coal containing $3 \%$ sulfur was tested and a $\mathrm{SO}_{2}$ removal rate of $77 \%$ was achieved at a $\mathrm{Ca} / \mathrm{S}$ molar ratio of 2 to 1 .

DOE has emphasized the use and further development of coal as an energy source for utilities and the industrial sector. At the same time, environmental responsibility has been mandated by the passage of the Clean Air Act Amendments of 1990. This Act establishes new lower emission levels

of $\mathrm{SO}_{2}$ from utility power plants, with Phase I of the regulations having come into effect in January. 1995, and the more stringent Phase II regulations beginning in January 2000. To realize full potential 
of coal as an energy source while still complying with the new air pollution regulations, the DOE initiated the Clean Coal Technology (CCT) Program.

The Clean Coal Technology (CCT) Program is a jointly funded government-industry effort to select the most promising advanced coal-based technologies and, over the next decade, move them into the commercial marketplace through demonstration. These demonstrations are conducted at a scale large enough to generate the data from design, construction, and operation that is necessary for the private sector to judge commercial potential and to make informed and confident decisions on commercial readiness.

The goal of the program is to make available to the U.S. energy marketplace, particularly the industrial and utility sectors, a number of advanced, more efficient, and environmentally responsive coal technologies. These technologies will reduce and/or eliminate the economic and environmental impediments that limit the full consideration of coal as a future energy resource. The program is being implemented through a series of five competitive solicitations which are now completed. Selections for the fifth solicitation were made in May 1993. Federal funding of $\$ 2.75$ billion is committed for the five rounds of the program. When the private sector cost share is included, total funding approaches $\$ 7$ billion. When the program is completed, clean coal technology options that will reduce the uncertainties of subsequent commercial-scale applications.

The intent as well as the objective of the DOE, as related to coal, has been endorsed most recently in the language of the Energy Policy Act of 1992 (Public Law 102-486). This legislation identifies a number of energy goals which already are a key part of the CCT Program, including achieving greater efficiencies in the conversion of coal to useful energy; achieving control of sulfur oxides, oxides of nitrogen, air toxics, solid and liquid wastes, greenhouse gases, or other emissions resulting from coal use; and promoting the export and transfer of U.S. clean coal technologies and services to developing countries and countries making the transition to free market economies.

$\mathrm{CCT}$ projects seek to demonstrate the commercial feasibility of the most promising advanced coal technologies that have already reached the proof-of-concept stage. These projects are conducted under jointly funded cooperative agreements-not contracts-between government and industry. The industrial partner in each project contributes at least $50 \%$ of the total cost-in many cases, more-and the patent rights for inventions developed during the demonstrations are normally granted to the participant. Each project involves a technology that the industrial partner believes has very real 
commercial potential. The program preserves incentives the industrial partner needs to subsequently bring the technology into the marketplace.

The emphasis in the program has evolved through the five rounds. Clean Coal I covered a broad range of advanced technologies. Clean Coal II focused on technologies to reduce acid rain precursors, especially those that can be applied to existing facilities using high-sulfur coal. Clean Coal III expanded the scope of the Clean Coal II solicitation to include coal-based technologies that help to meet future energy demands in an environmentally acceptable manner. Clean Coal IV included technologies to address similar needs in new as well as existing plants. The emphasis on high efficiency and high environmental performance has increased in each successive round of the program. Clean Coal V gave significant credit to projects that offer increased efficiency and environmental performance.

The LIFAC system was one of thirteen projects selected for funding under Round III of the CCT Program. A Cooperative Agreement between DOE and LIFAC NA was signed in November 1990. Due to scheduled outages at the host site, RP\&L's Whitewater Valley Unit No. 2 in Richmond, Indiana, design and procurement of critical equipment began in August 1990, with DOE funding contingent on final signing of the Cooperative Agreement.

\subsubsection{Project Organization}

The LIFAC demonstration was conducted by LIFAC NA, a joint venture partnership between ICF Kaiser Engineers, Inc. (ICF Kaiser) and Tampella Power Corporation. ICF Kaiser is a U.S. company based in Oakland, California, and a subsidiary of ICF Kaiser International, Inc., based in Fairfax, Virginia. Tampella Power is a subsidiary of a large diversified international company, Tampella Corporation, which is based in Tampere, Finland, and the original developer of the LIFAC technology.

LIFAC NA is responsible for the overall administration of the project and for providing the $50 \%$ matching funds. With the exception of project administration, most of the actual work is being performed by the two parent firms under service agreements with LIFAC NA. Both parent firms work closely with RP\&L and the other project team sponsors, including ICF Resources, EPRI, Indiana Corporation for Science and Technology (ICS\&T), and Black Beauty Coal Company. ICF Kaiser managed the demonstration project out of its Pittsburgh office, which provided excellent access 
to DOE representatives at the Pittsburgh Energy Technology Center. A project organization chart is provided in Figure 1-1.

\subsubsection{Host Site}

The project site for the LIFAC demonstration is RP\&L's Whitewater Valley Unit No. 2 pulverized coal-fired power station (60 MW), located in Richmond, Indiana. Richmond is approximately 75 miles east of Indianapolis, Indiana, and nearly 40 miles west of Dayton, Ohio. Whitewater Valley Unit No. 2, which began service in 1971, is a Combustion Engineering, tangentially-fired boiler which uses high-sulfur bituminous coal from Western Indiana. Actual power produced by the unit approaches $65 \mathrm{MW}$. As such, it is one of the smallest existing, tangentially-fired units in the United States. The furnace is 26 -feet, 11 -inches deep and 24-feet, 8 -inches wide and has a primary and secondary superheater. Tube sizes and spacings are designed to achieve the highest possible heattransfer rates with the least potential for gas-side fouling. The unit also has an inherent low draft-loss characteristic because of the lack of gas turns. At full load, 540,000 lbs/hr of steam are generated. The heat input at rated capacity is $651 \times 10^{6}$ Btu per hour. The design superheater outlet pressure and temperature are $1,320 \mathrm{psi}$ at $955^{\circ} \mathrm{F}$. The unit has a horizontal shaft basket-type air preheater. The flue gas temperature leaving the economizer is about $645^{\circ} \mathrm{F}$, while the flue gas temperature after the air preheater is about $316^{\circ} \mathrm{F}$. The balanced-draft unit has 12 burners.

In 1980 the unit was fitted and fully optimized with a state-of-the-art Low-NO $\mathrm{N}_{\mathrm{x}}$ Concentric Firing System (LNCFS). The LNCFS represents a very cost-effective means of reducing $\mathrm{NO}_{\mathrm{x}}$ emissions in comparison with other retrofit possibilities. The system works on the principle of directing secondary air along the sides of the furnace and creating a fuel rich zone in the center of the furnace. With the LNCFS, the excess air can be maintained below 20\%. Additionally, the installation reduces ash accumulation on the furnace walls, increasing heat absorption and reducing attemperation

requirements. With the LNCFS, each corner of the furnace has a tangential wind box consisting of three coal compartments and four auxiliary air compartments. At full load with all three $593 \mathrm{RB}$ coal pulverizers operating, primary transport air from the pulverizers amounts to $23 \%$ of the total combustion air. The capacity of one pulverizer is $26,400 \mathrm{lbs} / \mathrm{hr}$, with 52 grind coal with $70 \%$ minus 200 mesh.

Whitewater Valley Unit No. 2 has a Lodge Cottrell cold side precipitator which was erected with the boiler. The precipitator treats 227,000 actual cubic feet per minute of $316^{\circ} \mathrm{F}$ flue gas with 45,000 


\section{Figure 1-1 Project Organization}

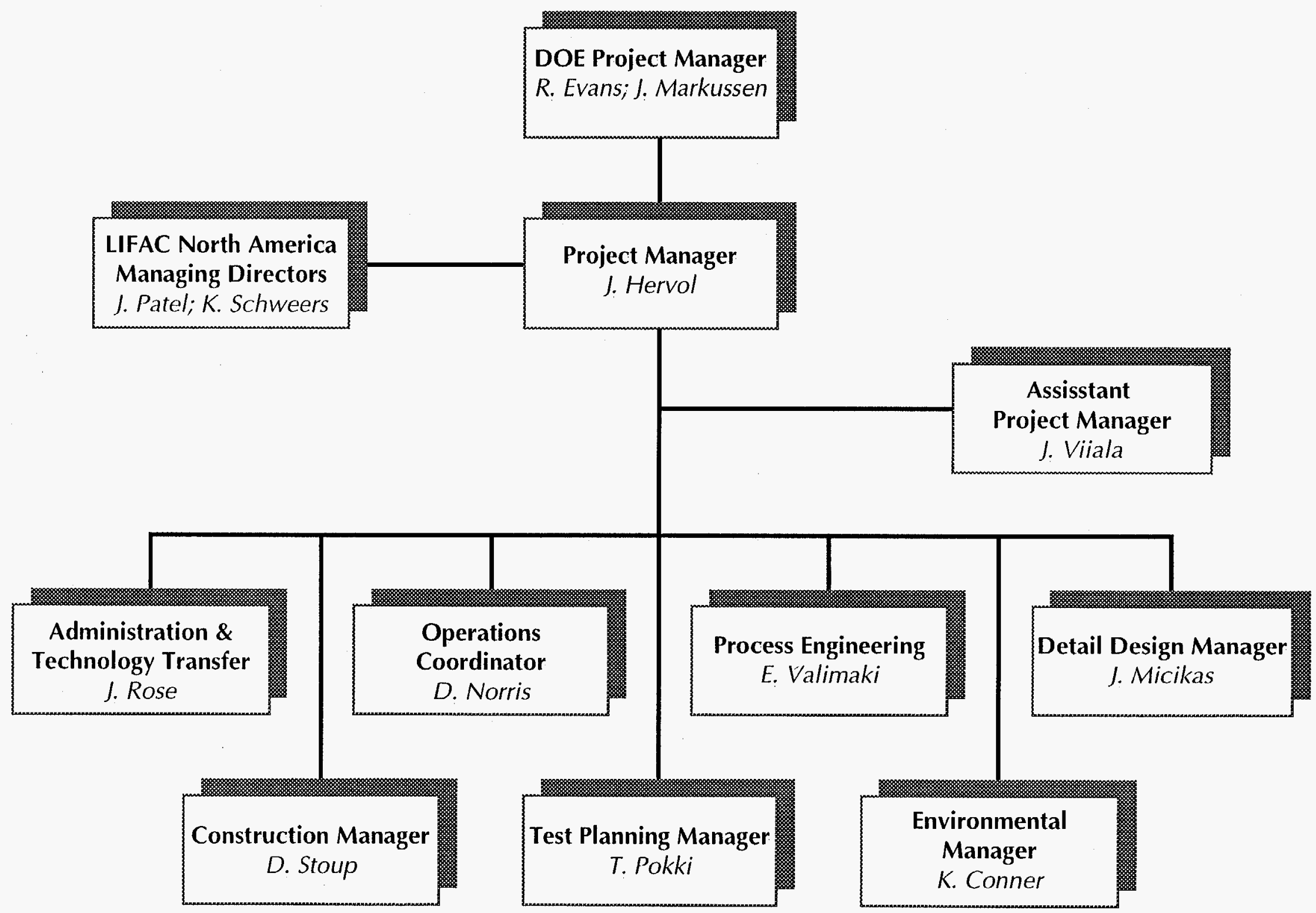


square feet of collection area (CA). Total CA of the ESP is 198 square feet/1,000 ACFM. The unit has two mechanical fields and four electrical fields and achieves $98.4 \%$ removal efficiency (from 3.9 $\mathrm{gr} / \mathrm{ft}^{3}$ to $0.06 \mathrm{gr} / \mathrm{ft}^{3}$ ). The ESP performance was optimized by Lodge Cottrell when RP\&L purchased new controls in 1985.

Whitewater Valley Unit No. 2's overall efficiency of $87.4 \%$ at full load has shown little variation over the years. The unit's average heat rate is $10,280 \mathrm{Btu} / \mathrm{kWh}$. At $60 \%$ of full load, the unit's efficiency increases to $88.17 \%$. The unit uses approximately 0.935 pounds of coal per $\mathrm{kWh}$ and generates 8.51 pounds of steam per $\mathrm{kWh}$.

The primary emissions monitored at the station are $\mathrm{SO}_{2}$ and opacity. $\mathrm{SO}_{2}$ emissions are calculated based on the coal analysis and are limited to $6 \mathrm{lbs} / 10^{6}$ Btu. Opacity is monitored using an in-situ meter located in the stack and is currently limited to $40 \%$. Current $\mathrm{SO}_{2}$ emissions for the unit are approximately $4 \mathrm{lbs} / 10^{6} \mathrm{BTU}$, while opacity at full load ranges from 15 to $30 \%$. Opacity at low load (40-MW) ranges from 3 to 5\%. Limited testing was conducted in November 1986 for $\mathrm{NO}_{\mathrm{x}}$ emissions. Results from the test work indicated that $\mathrm{NO}_{\mathrm{x}}$ emissions averaged $0.65 \mathrm{lbs} / 10^{6}$ BTU.

Whitewater Valley Unit No. 2 has several important qualities as a LIFAC demonstration site. One of these is that Whitewater Valley Unit No. 2 was the site of a prior demonstration of LIMB sorbent injection technology, jointly sponsored by EPRI and the U.S. Environmental Protection Agency (USEPA). Much of the sorbent injection equipment remained on-site and was used in the LIFAC demonstration. Another advantage of the site is that Whitewater Valley Unit No. 2 was a challenging candidate for a retrofit due to the cramped conditions at the site. The plant is, thus, typical of many U.S. power plants which are potential sites for application of LIFAC. In addition, the Whitewater Valley Unit No. 2 boiler is small relative to its capacity; hence, has a higher temperature profile relative to other boilers. This situation requires sorbent injection at higher points in the furnace to minimize deadburning of the reagent, but it decreases residence times needed for sulfur removal. The demonstration project was intended to show LIFAC's performance under operating conditions typical of U.S. power plants. The project demonstrated LIFAC on high-sulfur U.S. coals and was a logical extension of the Finnish demonstration work which is important for LIFAC's commercial success in the U.S. 


\subsubsection{Project Schedule}

To demonstrate the technical viability of the LIFAC process to economically reduce sulfur emissions from the Whitewater Valley Unit No. 2, LIFAC NA conducted a three-phase project, as follows:

$\begin{array}{lll}\text { - } & \text { Phase I: } & \text { Design } \\ \text { - } & \text { Phase IIA: } & \text { Long Lead Procurement } \\ \text { - } & \text { Phase IIB: } & \text { Construction } \\ \text { - } & \text { Phase III: } & \text { Operations }\end{array}$

Except for Phase IIA, each phase was comprised of three tasks: a management and administration task, a technical task, and an environmental task. The design phase began on August 8, 1990, and was scheduled to last six (6) months. Phase IIA, long lead procurement, overlaps the design phase and was expected to require about four (4) months to complete. The construction phase was to continue for another seven (7) months, while the operations phase was scheduled to last about twenty-six (26 months). Figure 1-2 shows the original estimated project schedule which is based on an August 8, 1990, start date and a planned outage of Whitewater Valley Unit No. 2 during March 1991.

It was during this outage that all the tie-ins and modifications to existing Unit No. 2 equipment were made. This required that the construction phase begin in early February 1991 -- construction was to be completed by the end of August 1991. Operations and testing were to begin September 1991, and continue for 26 months. However, the project encountered delays in receiving its construction permit. These delays, along with some design changes and an approved expansion in project scope, required that the Design Phase be extended by about eleven months. Therefore, construction was not completed until early June 1992. This represented an eight-month extension in the overall schedule.

During the last half of 1992, problems were encountered during startup and commissioning of some of the LIFAC components and systems. These problems required the parametric tests to be delayed until the first quarter 1993, which subsequently required adjustments in the entire testing schedule. During the initial parametric tests, problems were encountered with increased opacity levels. These problems forced an extension in the parametric test schedule, and, consequently, an adjustment was made to the testing schedule as shown in Figure 1-3. These delays, however, did not impact the 


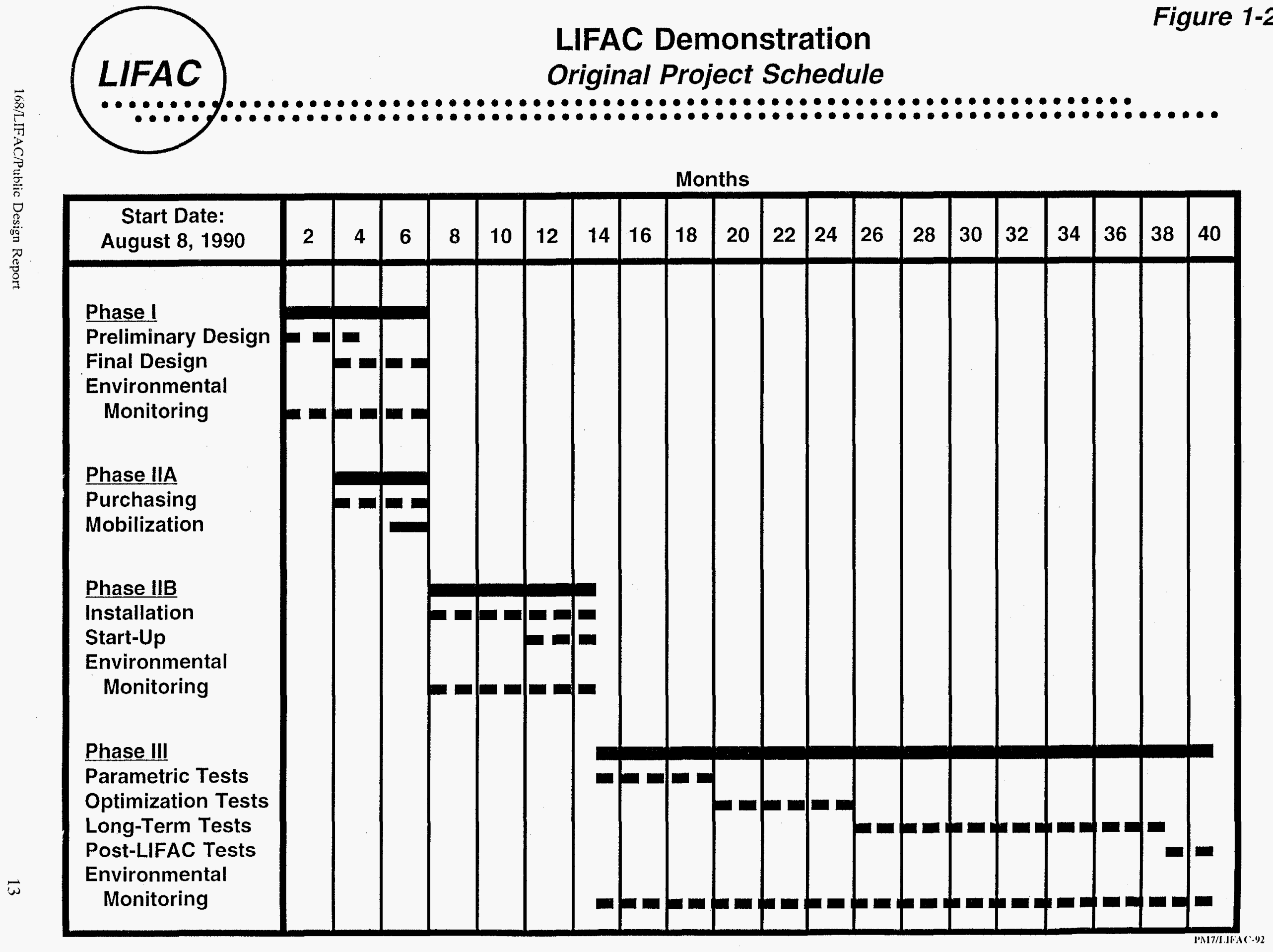




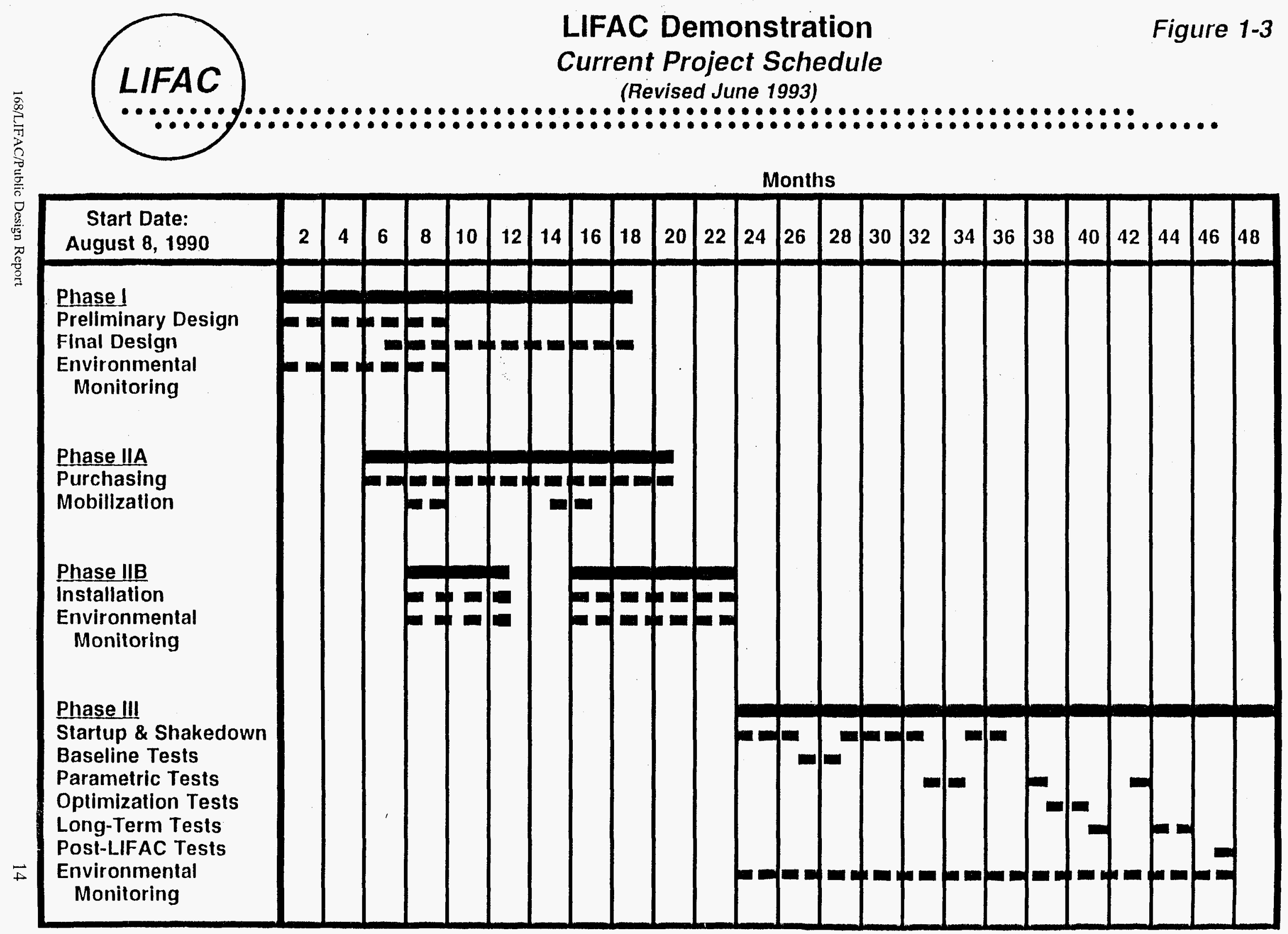


overall duration of the Phase III activities and the total project duration remained at the modified 48 months.

\subsubsection{Test Plan}

The test program had five sets of tests: baseline testing, parametric testing, optimization testing, longterm testing, and post-LIFAC testing. The baseline tests were designed to establish a set of current conditions at which the host's system operates and served as the basis of comparison for all other tests. The parametric tests consisted of determining the optimum settings of a wide range of process parameters. The parametric tests also tested the efficiency of different limestones as sorbents. The optimization tests were for the purpose of "fine-tuning" before the long-term tests. The aim of the optimization tests was to evaluate operability of the process in optimum process settings determined during the parametric tests. The long-term tests were long-duration tests. During these tests, the efficiency and economics of the process were to be evaluated with different coals. After the longterm tests, the baseline tests were repeated as post-LIFAC tests. A block diagram of the test program is shown below in Figure 1-4.

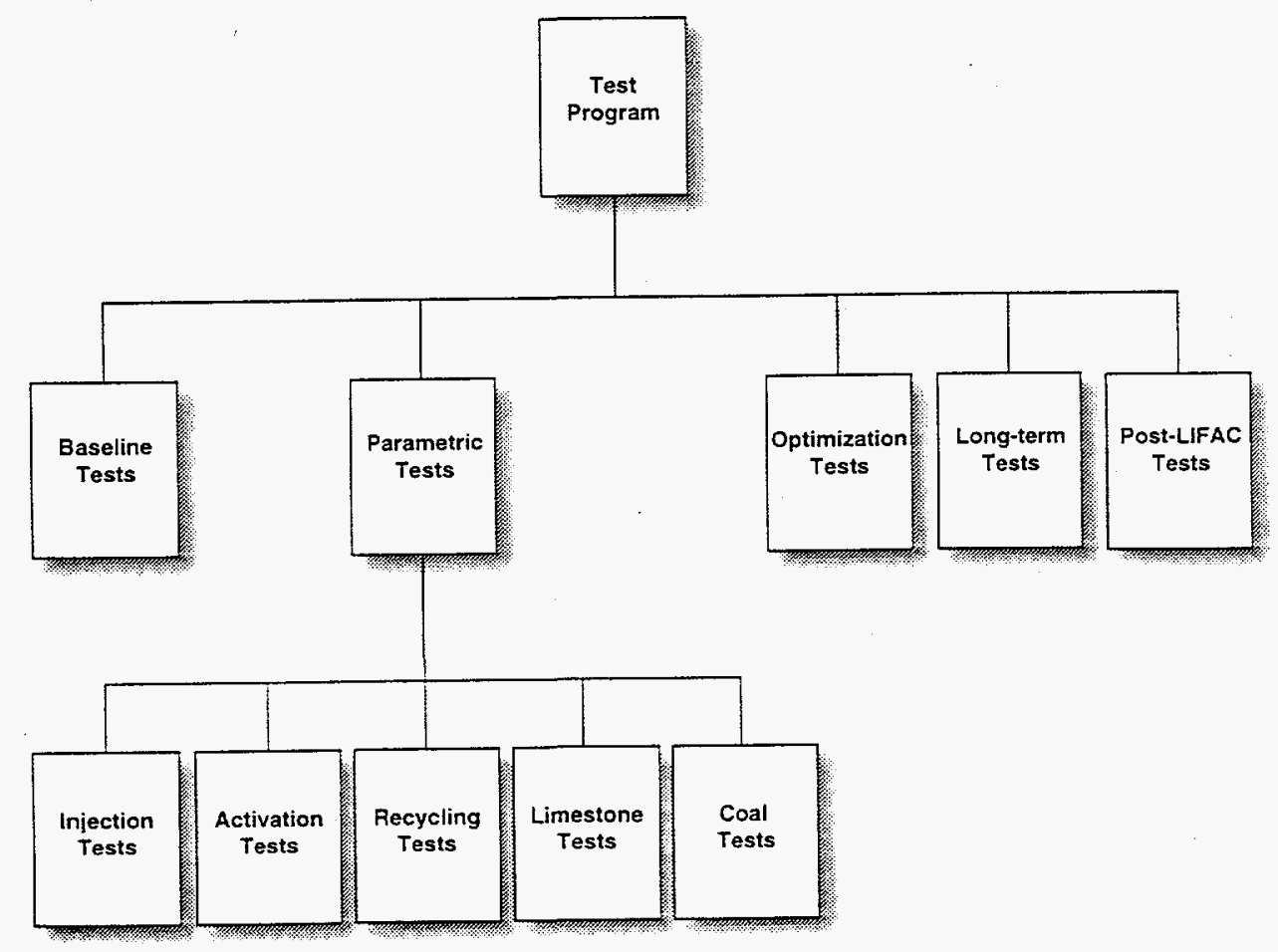

Figure 1-4

Structure of the LIFAC Desulfurization Process Test Program 


\subsection{Project Objectives}

The sponsors of this project believe that LIFAC has the potential to be a new and important $\mathrm{SO}_{2}$ control option for U.S. utilities subject to the Clean Air Act's acid rain regulations. To be considered as a commercially feasible option in this particular emission control market, LIFAC must demonstrate a high $\mathrm{SO}_{2}$ removal rate while remaining competitive with other options on a cost per ton of $\mathrm{SO}_{2}$ removed basis. To this end, the sponsors of this project designed the demonstration with the following objectives in mind:

- Sustained High $\mathrm{SO}_{2}$ Removal Rate - Incorporated into the test plan were several periods of long-term testing which were intended to demonstrate LIFAC's $\mathrm{SO}_{2}$ removal and reliability characteristics under normal operating conditions.

- Cost - LIFAC must compete with both low capital cost, low $\mathrm{SO}_{2}$ removal rate options such as sorbent injection, and high capital cost, high $\mathrm{SO}_{2}$ removal rate options such as wet scrubbing. This project was designed to demonstrate LIFAC's competitiveness on a cost per ton of $\mathrm{SO}_{2}$ removed basis with currently available alternatives.

- Retrofit Adaptability - The host site chosen required a retrofit with tight construction conditions that would prove LIFAC's ability to be installed where other technologies might not be possible. Construction was intended to also demonstrate LIFAC's ability to be built and brought on-line with zero plant downtime other than scheduled outages.

- System Compatibility - A major concern of utilities is the degree of compatibility of $\mathrm{SO}_{2}$ removal systems with their existing operations. This demonstration showed LIFAC's minimal impact on the host site's boiler and associated subsystems.

\subsection{Significance of the Project Commercialization and Process Advantages}

The significance of this project was to show that the LIFAC technology could provide $\mathrm{SO}_{2}$ removal at a significant rate and competitive costs, while utilizing U.S. coals. A successful demonstration would provide another option for power plants besides costly wet scrubbers, with minimal impacts to the host site. 
Wet scrubbers are the most prevalent FGD technology and account for approximately 90\% of U.S. scrubber systems. Wet FGD systems that use lime or limestone remove about $90 \%$ of the $\mathrm{SO}_{2}$ and usually produce a sulfite/sulfate sludge waste product. Although the LIFAC process cannot match the high removal rates ( $90 \%$ or more) achieved by conventional wet scrubbers, the process does offer several advantages including:

- The technology can be more easily retrofit onto most small power plants (100-150 MW). The vertical activation chamber requires less space. However, with larger boilers (450-500 MW) several LIFAC systems would be required at which point wet scrubbers are more feasible.

- The technology has lower capital costs which makes it especially attractive to existing plants that have fewer years to amortize capital investments as compared to long-lived power plants.

- The technology uses a widely available reagent, limestone, rather than more expensive sorbent materials, such as lime.

- The need for slurry preparation/handling equipment is eliminated.

- The waste product is dry and easy to handle. In comparison, conventional wet limestone scrubbers produce a wet sludge which requires special handling and treatment.

- The technology is typically compatible with other plant systems such as electrostatic precipitators (ESPs) and induced draft (ID) fans, thereby minimizing costly retrofit plant modifications in order to employ the technology.

The LIFAC system also has potential advantages over less conventional sorbent injection systems now being tested. These include:

Use of limestone as opposed to lime or other more expensive sorbents.

- Removal rates of $75-85 \%$, which exceed the removal rates of many dry sorbent injection systems. 
- Improved control of wall deposition and fouling associated with humidification in vertical chamber as opposed to in-duct humidification.

The LIFAC technology's potential for commercialization is increased by its ability to remove $75-85 \%$ of the $\mathrm{SO}_{2}$, its low space requirement, and its low retrofit costs.

\subsection{DOE's Role in the Project}

The DOE was responsible for monitoring all aspects of the project and for granting or denying all approvals required by the Cooperative Agreement. The DOE Contracting Officer is DOE's authorized representative for all matters related to the Cooperative Agreement.

The DOE Contracting Officer appointed a Contracting Officer's Technical Representative (COTR) who is the authorized representative for all technical matters and has the authority to issue "Technical Advice" which may:

m Suggest redirection of the cooperative Agreement effort, recommend a shifting of work emphasis between work areas or tasks, and suggest pursuit of certain lines of inquiry which assist in accomplishing the Statement of Work.

- Approve those reports, plans, and items of technical information required to be delivered by the Participant to DOE under the Cooperative Agreement.

The DOE COTR does not have the authority to issue any technical advice which:

- Constitutes an assignment of additional work outside the Statement of Work.

- In any manner causes an increase or decrease in the total estimated cost or the time required for performance of the Cooperative Agreement.

- Interferes with the Participant's right to perform the terms and conditions of the Cooperative Agreement. 


\subsection{TECHNOLOGY DESCRIPTION}

\subsection{Chemical Process}

The LIFAC (Limestone Injected into the Furnace with Activation of untreated Calcium oxide) technology combines upper-furnace limestone injection followed by post-furnace humidification in an activation reactor located between the air preheater and the ESP. The process produces a dry and stable by-product that is partially removed from the bottom of the activation reactor and partially removed at the ESP.

Finely pulverized limestone $(80 \%<325$ mesh) is pneumatically conveyed and injected into the upper part of the furnace. Since the temperatures at the point of injection are in the range of $1800-2000$ ${ }^{\circ} \mathrm{F}$, the limestone $\left(\mathrm{CaCO}_{3}\right)$ thermally decomposes to form calcium oxide $(\mathrm{CaO})$. As the $\mathrm{CaO}$ passes through the furnace, initial desulfurization reactions occur. A portion of the sulfur dioxide $\left(\mathrm{SO}_{2}\right)$ reacts with the $\mathrm{CaO}$ to form calcium sulfite $\left(\mathrm{CaSO}_{3}\right)$ which oxidizes to calcium sulfate $\left(\mathrm{CaSO}_{4}\right)$. Essentially all of the sulfur trioxide $\left(\mathrm{SO}_{3}\right)$ reacts with $\mathrm{CaO}$ to form $\mathrm{CaSO}_{4}$.

The flue gas, unreacted $\mathrm{CaO}$, and ash exit the boiler and pass through the air preheater. On leaving the air preheater, the gas/CaO/ash mixture is directed to the LIFAC activation reactor. In the reactor, additional $\mathrm{SO}_{2}$ capture occurs after the flue gas is humidified with a water spray. Humidification converts $\mathrm{CaO}$ to calcium hydroxide, $\mathrm{Ca}(\mathrm{OH})_{2}$, which enhances further $\mathrm{SO}_{2}$ removal. The primary reaction product in the activation reactor is calcium sulfite $\left(\mathrm{CaSO}_{3}\right)$. The activation reactor is designed to allow time for effective humidification of the flue gas, activation of the $\mathrm{CaO}$, and reaction of $\mathrm{SO}_{2}$ with the sorbent. All the water droplets evaporate before the flue gas leaves the activation reactor. The net effect is that at a $\mathrm{Ca} / \mathrm{S}$ molar ratio in the range of $2: 1$ to $2.5: 1,75$ $85 \%$ of the $\mathrm{SO}_{2}$ is removed from the flue gas.

The flue gas leaving the activation reactor enters the existing ESP, where the spent sorbent and fly ash are removed from the flue gas and sent to the disposal facilities. The solids collected by the ESP consist of fly ash, $\mathrm{CaCO}_{3}, \mathrm{CaO}, \mathrm{Ca}(\mathrm{OH})_{2}, \mathrm{CaSO}_{4}$, and $\mathrm{CaSO}_{3}$. To improve utilization of the calcium and increase $\mathrm{SO}_{2}$ removal, a portion of the spent sorbent collected in the ESP hoppers is recycled to the ductwork just ahead of the activation reactor. 
Figure 2-1 is a simple flow diagram of the LIFAC process as designed at the RP\&L host site. The major process areas are as follows:

- Limestone Storage and Handling Area

- Boiler Injection Area

- Activation Reactor Area

- ESP Ash Recycle Area

- Process Monitoring and Control

(These areas are discussed in detail in Section 3.2.)

Note that proprietary information within the reactor consists of the following:

- Specific residence time

- Water droplet sizes

- Distribution mechanism 
Figure 2-1 LIFAC Overall Block Flow Diagram

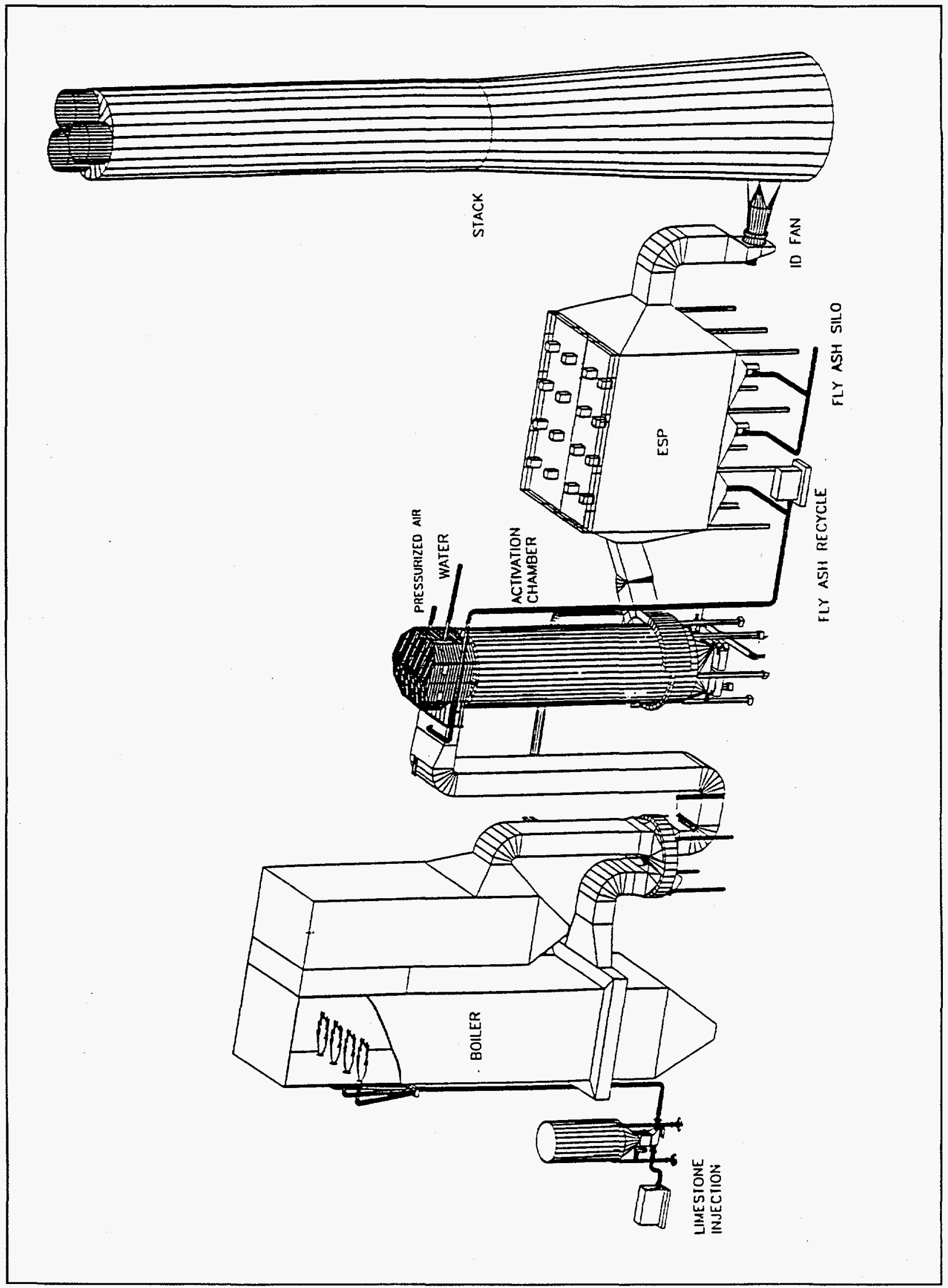


The calculated design values for LIFAC are based on certain assumptions regarding Whitewater Valley Unit No. 2, the typical coal burned at the facility, and the predicted sorbent quality. Ultimate and proximate analyses of the reference coal were completed during the design phase. Table $3 \mathrm{~A}$ below shows the coal analysis and other assumptions which were used in the preliminary design calculations. Copies of the coal analysis are provided in Appendix I. The flow values presented in the following subsection are based on the values shown in Table $3 \mathrm{~A}$.

\begin{tabular}{|lr|}
\hline \multicolumn{2}{|c|}{ COAL ANALYSIS: } \\
Higher Heating Value & 11178 Btu/lb \\
Carbon & $62 \%$ \\
Sulfur & $2.4 \%$ \\
Oxygen & $7 \%$ \\
Nitrogen & $1.2 \%$ \\
Hydrogen & $4.4 \%$ \\
Ash & $10 \%$ \\
Moisture & $13 \%$ \\
TOTAL & $100 \%$ \\
\hline
\end{tabular}

\begin{tabular}{|c|c|}
\hline \multicolumn{2}{|c|}{ DESIGN $\overline{B A S I S:}$} \\
\hline Generating Efficiency & $33 \%$ \\
\hline Excess Air Factor & 1.304 \\
\hline Air Preheater Leakage & $7 \%$ \\
\hline Humidification Rate & $80 \%$ \\
\hline Ca/S Molar Ratio & 2.00 \\
\hline Limestone Purity $\left(\% \mathrm{CaCO}_{3}\right)$ & $90 \%$ \\
\hline Furnace Bottom Ash & $\begin{array}{l}15 \% \text { without LIFAC } \\
10 \% \text { with LIFAC* }\end{array}$ \\
\hline Air Preheater Ash & $5 \%$ \\
\hline
\end{tabular}

*Same quantity with or without LIFAC accounts for limestone injection and assumes $100 \%$ ash removal.

Table $3 A \quad$ Process Values Used for Preliminary Design Calculations 


\title{
3.1 Process Flow Diagram
}

A process flow diagram was developed for the LIFAC desulfurization process. In Table 3B, thirtythree process streams are identified, showing flow rates, pressures, and temperatures at both high (65 $\mathrm{MW}$ ) and low (40 MW) boiler loads. Figure 3-3 is a flow diagram of LIFAC as it was installed at RP\&L. The figure provides the physical locations of all the process streams referred to in the tables. Table $3 \mathrm{C}$ displays the maximum, or worst case, process values which were used as an upper limit for the range of design values.

\subsection{Process Areas}

The nature and physical layout of the host site, combined with its history as the location of a previous demonstration project, helped to define some of this project's design criteria. In 1989, RP\&L served as the host site for the demonstration of a lime injection system under the acronym of LIMB. Much of the equipment installed for that project remained on-site, and its reuse for LIFAC was considered where possible. In addition, RP\&L's Unit No. 2 boiler is small, with tight surrounding clearances which had to be accounted for in the design of the LIFAC boilerhouse equipment and installation procedures. Also included in the design criteria was the need to install all the necessary tie-ins to plant systems during Unit No. 2's short downtime periods. The remaining construction period for LIFAC could not interfere with normal daily plant operations.

The LIFAC system at RP\&L can be divided into the following five design areas:

\author{
- Limestone Storage and Handling Area \\ - Boiler Injection Area \\ - Activation Reactor Area \\ - ESP Ash Recycle Area \\ - Process Monitoring and Control
}

\subsubsection{Limestone Storage and Handling Area}

The majority of the equipment remaining from the previous lime injection demonstration was used for handling and storage of the hydrated lime. Figure 3-5 is a mechanical arrangement (plan) drawing of the limestone storage and handling area. Existing equipment is shown using dashed lines. Because 
TABLE 3B

\section{NORMAL LIFAC FLOW VALUES \\ AT HIGH AND LOW BOILER LOADS \\ (Refer to Figure 3-3 for Location of Components)}

\begin{tabular}{|c|c|c|c|c|c|c|c|}
\hline \multirow{2}{*}{ No. } & \multirow{2}{*}{ Component } & \multicolumn{3}{|c|}{$65 \mathrm{MW}$} & \multicolumn{3}{|c|}{$40 \mathrm{MW}$} \\
\hline & & Flow & Pressure & Temperature & Flow & Pressure & Temperature \\
\hline 1 & Sorbent & $404 \mathrm{lbs} / \mathrm{min}$ & -- & $70 \mathrm{~F}$ & $404 \mathrm{lbs} / \mathrm{min}$ & -- & $70 \mathrm{~F}$ \\
\hline 2 & Sorbent & $400 \mathrm{lbs} / \mathrm{min}$ & - & $70 \mathrm{~F}$ & $400 \mathrm{lbs} / \mathrm{min}$ & - & $70 \mathrm{~F}$ \\
\hline 3 & Sorbent & $200 \mathrm{Ibs} / \mathrm{min}$ & - & $70 \mathrm{~F}$ & $123 \mathrm{lbs} / \mathrm{min}$ & - & $70 \mathrm{~F}$ \\
\hline 4 & Injection Air & $759 \mathrm{acfm}$ & $11.6 \mathrm{psig}$ & $175 \mathrm{~F}$ & $759 \mathrm{acfm}$ & 11.6 psig & $175 \mathrm{~F}$ \\
\hline 5 & Secondary Air & $4269 \mathrm{acfm}$ & 1.73 psig & $95 \mathrm{~F}$ & 4269 actm & 1.73 psig & $95 \mathrm{~F}$ \\
\hline 6 & Total Sorbent Air & $6034 \mathrm{acfm}$ & 0 psig & $100 \mathrm{~F}$ & $6034 \mathrm{acfm}$ & 0 psig & $100 \mathrm{~F}$ \\
\hline 7 & Coal & $336 \mathrm{lbs} / \mathrm{min}$ & -- & $70 \mathrm{~F}$ & $206 \mathrm{lbs} / \mathrm{min}$ & -- & $70 \mathrm{~F}$ \\
\hline 8 & Coal & $336 \mathrm{lbs} / \mathrm{min}$ & -- & $70 \mathrm{~F}$ & $206 \mathrm{lbs} / \mathrm{min}$ & -- & $70 \mathrm{~F}$ \\
\hline 9 & Coal & $336 \mathrm{lbs} / \mathrm{min}$ & -- & $70 \mathrm{~F}$ & $206 \mathrm{lbs} / \mathrm{min}$ & -- & $70 \mathrm{~F}$ \\
\hline 10 & Sorbent Air & $521 \mathrm{acfm}$ & 7.25 psig & $145 \mathrm{~F}$ & $521 \mathrm{acfm}$ & 7.25 psig & $145 \mathrm{~F}$ \\
\hline 11 & Turbine Steam & $9000 \mathrm{lbs} / \mathrm{min}$ & 1320 psig & $955 \mathrm{~F}$ & $5400 \mathrm{lbs} / \mathrm{min}$ & 1275 psig & $955 \mathrm{~F}$ \\
\hline 12 & Bottom Ash & $28 \mathrm{lbs} / \mathrm{min}$ & -- & - & $17 \mathrm{lbs} / \mathrm{min}$ & -- & -- \\
\hline 13 & Flue Gas after Econ. & $336700 \mathrm{acfm}$ & $-4.7 " \mathrm{H}_{2} \mathrm{O}$ & $665 \mathrm{~F}$ & $192800 \mathrm{acfm}$ & $-1.7 " \mathrm{H}_{2} \mathrm{O}$ & $577 \mathrm{~F}$ \\
\hline 14 & Fly Ash after Econ. & $251 \mathrm{lbs} / \mathrm{min}$ & -- & $665 \mathrm{~F}$ & $154 \mathrm{lbs} / \mathrm{min}$ & - & $577 \mathrm{~F}$ \\
\hline 15 & Preheater Ash & $14 \mathrm{lbs} / \mathrm{min}$ & -- & -- & $9 \mathrm{lbs} / \mathrm{min}$ & -- & -- \\
\hline 16 & Preheated Air & $228043 \mathrm{acfm}$ & $10.6 " \mathrm{H}_{2} \mathrm{O}$ & $530 \mathrm{~F}$ & $130990 \mathrm{acfm}$ & $10.6 " \mathrm{H}_{2} \mathrm{O}$ & $471 \mathrm{~F}$ \\
\hline 17 & Flue Gas & $263600 \mathrm{acfm}$ & $-12.6^{\prime \prime} \mathrm{H}_{2} \mathrm{O}$ & $347 \mathrm{~F}$ & $152000 \mathrm{acfm}$ & $-4.3 " \mathrm{H}_{2} \mathrm{O}$ & $299 \mathrm{~F}$ \\
\hline 18 & Fly Ash & $237 \mathrm{lbs} / \mathrm{min}$ & -- & $347 \mathrm{~F}$ & $145 \mathrm{lbs} / \mathrm{min}$ & - & $299 \mathrm{~F}$ \\
\hline 19 & Flue Gas after Reheat & $228800 \mathrm{acfm}$ & $-16.7 " \mathrm{H}_{2} \mathrm{O}$ & $167 \mathrm{~F}$ & $138100 \mathrm{acfm}$ & $-5.8 " \mathrm{H}_{2} \mathrm{O}$ & $167 \mathrm{~F}$ \\
\hline 20 & Fly Ash after Reheat & $427 \mathrm{lbs} / \mathrm{min}$ & - & $167 \mathrm{~F}$ & $262 \mathrm{lbs} / \mathrm{min}$ & - & $167 \mathrm{~F}$ \\
\hline 21 & Nozzle Air & $326 \mathrm{acfm}$ & 80 psig & $104 \mathrm{~F}$ & 337 acfm & 80 psig & $104 \mathrm{~F}$ \\
\hline 22 & Nozzle Water & $103 \mathrm{gpm}$ & 48 psig & $50 \mathrm{~F}$ & $49 \mathrm{gpm}$ & 28 psig & $50 \mathrm{~F}$ \\
\hline 23 & Vibrator Air & $70 \mathrm{acfm}$ & 101.5 psig & $104 \mathrm{~F}$ & $70 \mathrm{acfm}$ & $101.5 \mathrm{psig}$ & $104 \mathrm{~F}$ \\
\hline 24 & Dumpster/Truck Slag & $58 \mathrm{lbs} / \mathrm{min}$ & -- & $122 \mathrm{~F}$ & $35 \mathrm{lbs} / \mathrm{min}$ & -- & $122 \mathrm{~F}$ \\
\hline 25 & Flue Gas & 221500 acfm & $-15.3 " \mathrm{H}_{2} \mathrm{O}$ & $149 \mathrm{~F}$ & $134000 \mathrm{acfm}$ & $-5.2 " \mathrm{H}_{2} \mathrm{O}$ & $149 \mathrm{~F}$ \\
\hline 26 & Fly Ash & $427 \mathrm{lbs} / \mathrm{min}$ & - & $149 \mathrm{~F}$ & $262 \mathrm{lbs} / \mathrm{min}$ & -- & $149 \mathrm{~F}$ \\
\hline 27 & Reheat Steam & $103 \mathrm{lbs} / \mathrm{min}$ & 244 psig & $570 \mathrm{~F}$ & $65 \mathrm{lbs} / \mathrm{min}$ & 244 psig & $570 \mathrm{~F}$ \\
\hline 28 & Condensate Water & $12.3 \mathrm{gpm}$ & 101.5 psig & $325 \mathrm{~F}$ & $7.8 \mathrm{gpm}$ & $101.5 \mathrm{psig}$ & $325 \mathrm{~F}$ \\
\hline 29 & Recirc. Fly Ash & $248 \mathrm{lbs} / \mathrm{min}$ & - & $122 \mathrm{~F}$ & $152 \mathrm{lbs} / \mathrm{min}$ & -- & $122 \mathrm{~F}$ \\
\hline 30 & ESP Transport Air & $681 \mathrm{acfm}$ & 70 psig & $140 \mathrm{~F}$ & $681 \mathrm{acfm}$ & 7.0 psig & $140 \mathrm{~F}$ \\
\hline 31 & System Fly Ash & $178 \mathrm{lbs} / \mathrm{min}$ & - & $167 \mathrm{~F}$ & $108 \mathrm{lbs} / \mathrm{min}$ & -- & $167 \mathrm{~F}$ \\
\hline 32 & Particulate Matter & $1.7 \mathrm{lbs} / \mathrm{min}$ & -- & $158 \mathrm{~F}$ & $10 \mathrm{lbs} / \mathrm{min}$ & - & $158 \mathrm{~F}$ \\
\hline 33 & Flue Gas & $228100 \mathrm{acfm}$ & $-21 " \mathrm{H}_{2} \mathrm{O}$ & $158 \mathrm{~F}$ & $136500 \mathrm{acfm}$ & $-6.8 " \mathrm{H}_{2} \mathrm{O}$ & $158 \mathrm{~F}$ \\
\hline
\end{tabular}




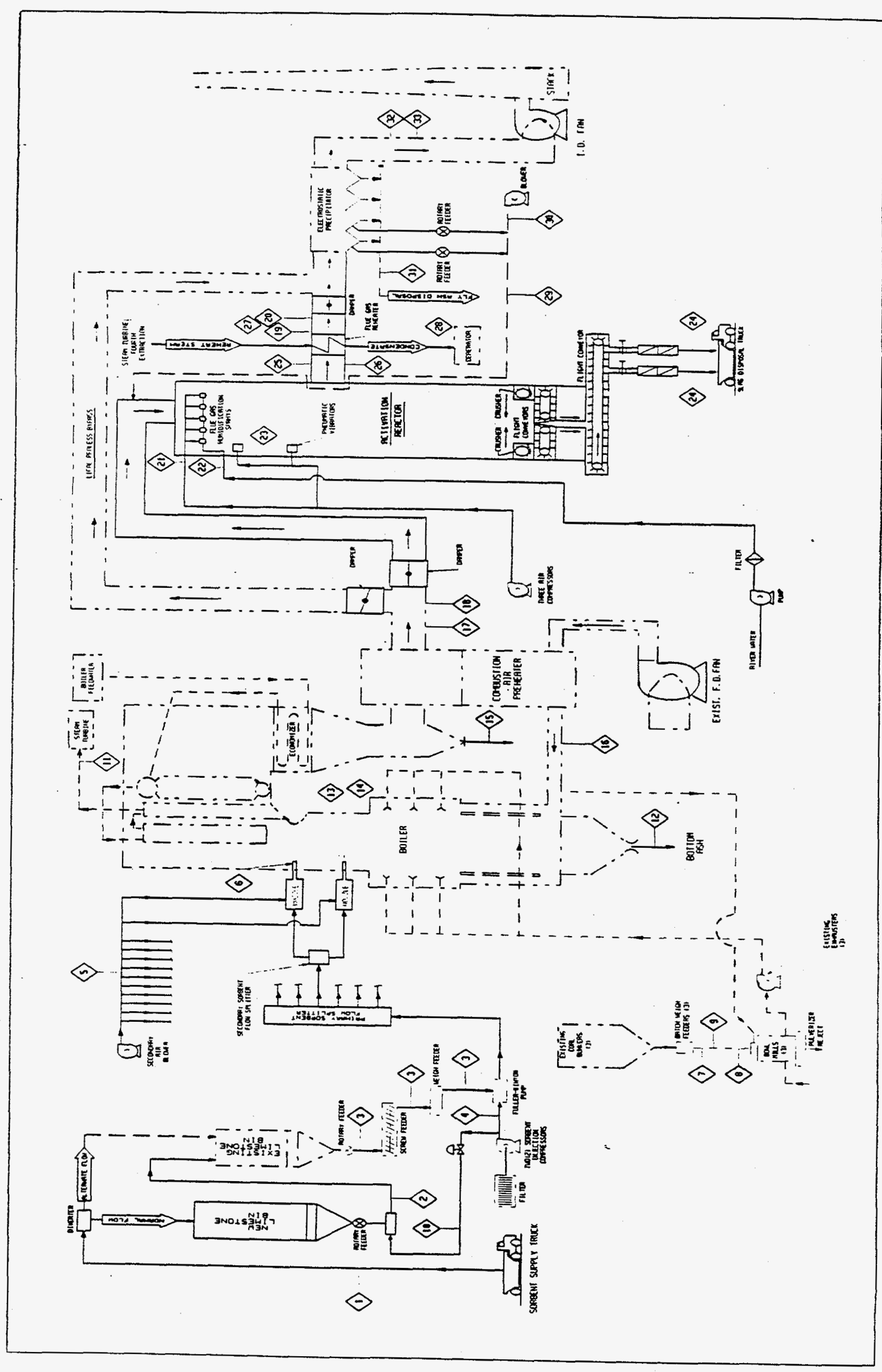

$\frac{E}{\sigma}$
$\frac{\pi}{\sigma}$
$\frac{\pi}{0}$

$\frac{3}{1}$

s
0
0
0
0

들

$\underset{1}{ \pm}$

$m$

일 
TABLE 3C

MAXIMUM LIFAC FLOW VALUES AT 65 MW

(Refer to Figure 3-3 for Location of Components)

\begin{tabular}{|c|c|c|c|c|}
\hline \multirow{2}{*}{ No. } & \multirow{2}{*}{ Component } & \multicolumn{3}{|c|}{$65 \mathrm{MW}$} \\
\hline & & Flow & Pressure & Temperature \\
\hline 1 & Sorbent & $417 \mathrm{lbs} / \mathrm{min}$ & -- & $70 \mathrm{~F}$ \\
\hline 2 & Sorbent & $400 \mathrm{lbs} / \mathrm{min}$ & -- & $70 \mathrm{~F}$ \\
\hline 3 & Sorbent & $300 \mathrm{lbs} / \mathrm{min}$ & -- & $70 \mathrm{~F}$ \\
\hline 4 & Injection Air & $759 \mathrm{acfm}$ & 11.6 psig & $175 \mathrm{~F}$ \\
\hline 5 & Secondary Air & $6237 \mathrm{acfm}$ & 1.73 psig & $95 \mathrm{~F}$ \\
\hline 6 & Total Sorbent Air & $8448 \mathrm{acfm}$ & -- & $100 \mathrm{~F}$ \\
\hline 7 & Coal & $336 \mathrm{lbs} / \mathrm{min}$ & -- & $70 \mathrm{~F}$ \\
\hline 8 & Coal & $336 \mathrm{lbs} / \mathrm{min}$ &.- & $70 \mathrm{~F}$ \\
\hline 9 & Coal & $336 \mathrm{lbs} / \mathrm{min}$ & -- & $70 \mathrm{~F}$ \\
\hline 10 & Sorbent Air & $521 \mathrm{acfm}$ & $7.25 \mathrm{psig}$ & $145 \mathrm{~F}$ \\
\hline 11 & Turbine Steam & $9000 \mathrm{lbs} / \mathrm{min}$ & $1320 \mathrm{psig}$ & $955 \mathrm{~F}$ \\
\hline 12 & Bottom Ash & $37 \mathrm{lbs} / \mathrm{min}$ & -- & -- \\
\hline 13 & Flue Gas after Econ. & $360200 \mathrm{acfm}$ & $-4.7 " \mathrm{H}_{2} \mathrm{O}$ & $665 \mathrm{~F}$ \\
\hline 14 & Fly Ash after Econ. & $330 \mathrm{lbs} / \mathrm{min}$ & -- & $665 \mathrm{~F}$ \\
\hline 15 & Preheater Ash & $18 \mathrm{lbs} / \mathrm{min}$ & - & - \\
\hline 16 & Preheated Air & $228043 \mathrm{acfm}$ & $10.6 " \mathrm{H}_{2} \mathrm{O}$ & $530 \mathrm{~F}$ \\
\hline 17 & Flue Gas & $282100 \mathrm{acfm}$ & $-12.6 " \mathrm{H}_{2} \mathrm{O}$ & $347 \mathrm{~F}$ \\
\hline 18 & Fly Ash & $312 \mathrm{lbs} / \mathrm{min}$ & -- & $347 \mathrm{~F}$ \\
\hline 19 & Flue Gas after Reheat & $247000 \mathrm{acfm}$ & $-16.7^{\prime \prime} \mathrm{H}_{2} \mathrm{O}$ & $167 \mathrm{~F}$ \\
\hline 20 & Fly Ash after Reheat & $562 \mathrm{lbs} / \mathrm{min}$ & - & $167 \mathrm{~F}$ \\
\hline 21 & Nozzle Air & $337 \mathrm{acfm}$ & $101.5 \mathrm{psig}$ & $104 \mathrm{~F}$ \\
\hline 22 & Nozzle Water & $115 \mathrm{gpm}$ & 64 psig & $50 \mathrm{~F}$ \\
\hline 23 & Vibrator Air & 70 acfm & $101.5 \mathrm{psig}$ & $104 \mathrm{~F}$ \\
\hline 24 & Dumpster/Truck Slag & $1467 \mathrm{los} / \mathrm{min}$ & - & $122 \mathrm{~F}$ \\
\hline 25 & Flue Gas & $239100 \mathrm{acfm}$ & $-15.3 " \mathrm{H}_{2} \mathrm{O}$ & $149 \mathrm{~F}$ \\
\hline 26 & Fly Ash & $562 \mathrm{lbs} / \mathrm{min}$ & - & $149 \mathrm{~F}$ \\
\hline 27 & Reheat Steam & $112 \mathrm{lbs} / \mathrm{min}$ & 244 psig & $570 \mathrm{~F}$ \\
\hline 28 & Condensate Water & $13.4 \mathrm{gpm}$ & $101.5 \mathrm{psig}$ & $325 \mathrm{~F}$ \\
\hline 29 & Recirc. Fly Ash & $324 \mathrm{lbs} / \mathrm{min}$ & -- & $122 \mathrm{~F}$ \\
\hline 30 & ESP Transport Air & $681 \mathrm{acfm}$ & $7.0 \mathrm{psig}$ & $140 \mathrm{~F}$ \\
\hline 31 & System Fly Ash & $310 \mathrm{lbs} / \mathrm{min}$ & $\overline{--}$ & $167 \mathrm{~F}$ \\
\hline 32 & Particulate Matter & $2.2 \mathrm{lbs} / \mathrm{min}$ & - & $158 \mathrm{~F}$ \\
\hline 33 & Flue Gas & $246200 \mathrm{acfm}$ & $-27^{\prime \prime} \mathrm{H}_{2} \mathrm{O}$ & $158 \mathrm{~F}$ \\
\hline
\end{tabular}




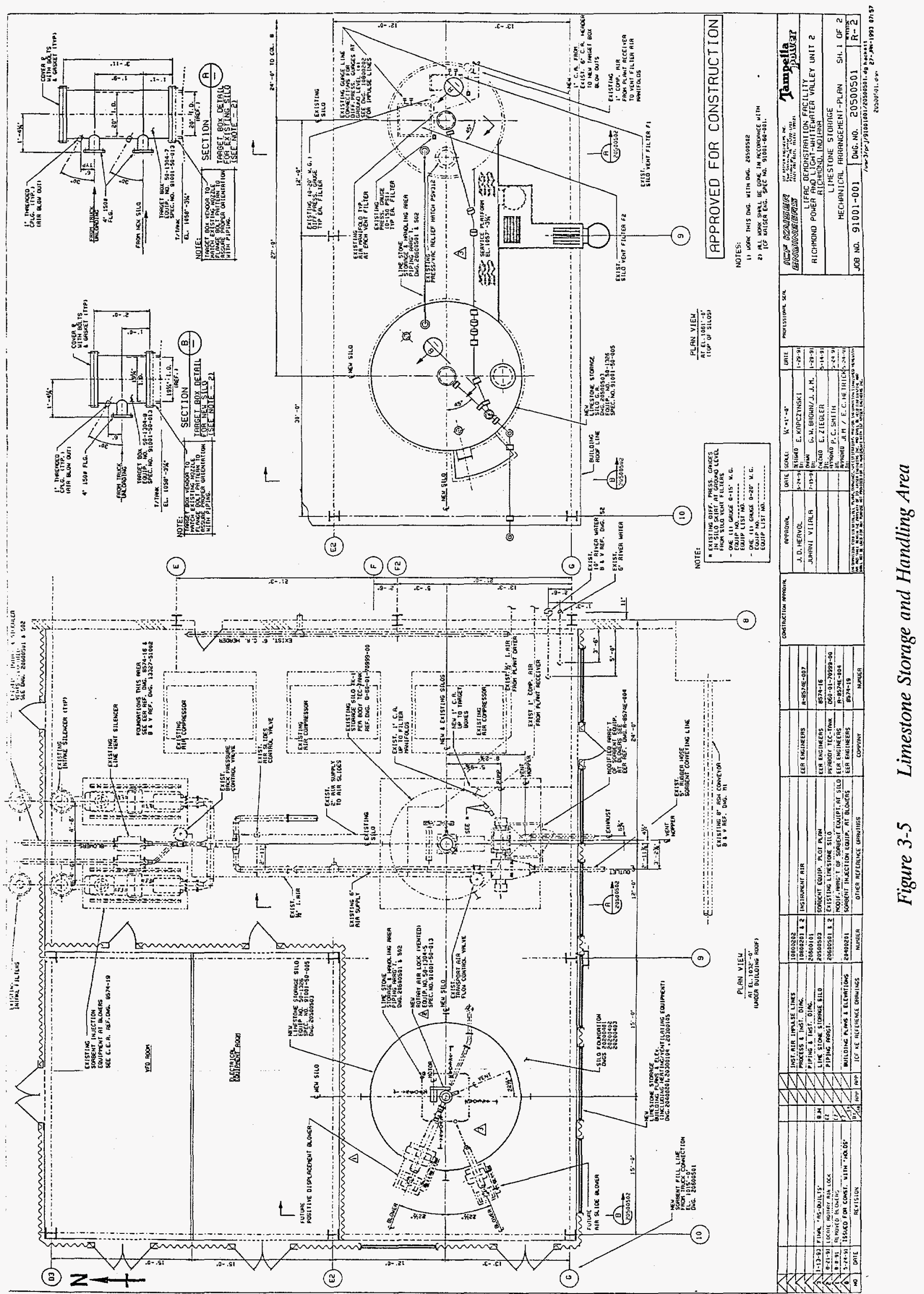


of the similarities between the physical characteristics of limestone and hydrated lime, the utilization of this equipment was a high priority in designing the limestone system. Inspection of this equipment allowed reuse of the following items:

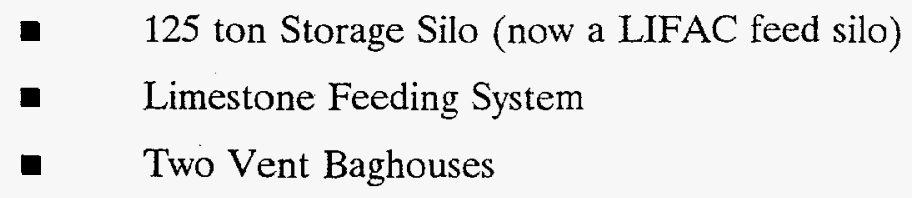

The LIFAC system was designed for operation on a continuous basis at a limestone injection rate of $200 \mathrm{lb} / \mathrm{min}$, which necessitated the inclusion of additional limestone storage and handling equipment. A new 250 ton storage silo was designed to provide enough storage capacity for LIFAC to operate three days, such as over a weekend, without any limestone deliveries.

The pulverized limestone arrives at the plant via truck transport. A pneumatic transport line which can serve either the new or existing silo was designed with a maximum operating pressure of 16 psi and flow rate of $17 \mathrm{lb} / \mathrm{min}$. The transport line has replaceable wear back fittings on all elbows along with Victaulic couplings. A manual diverter valve on the roof of the new silo directs the limestone to either of the two silos.

Limestone is transported pneumatically from the new storage silo to the existing silo for injection into the boiler. The new silo has air slides which fluidize the limestone and ensure an even, continuous flow of material by gravity to a rotary valve. The rotary valve feeds a conveying tee where transport air is introduced to carry the limestone to the top of the existing silo. The capacity of the transport pipe is $400 \mathrm{lb} / \mathrm{min}$ of limestone. The transport air is supplied by a new rotary lobe air blower with a maximum capacity of 1600 ACFM at 12 psig.

Limestone quantity in the silos is determined by measuring the weight of the silos with weight cells. Both the new and existing silo have a set of level indicators. The new silo has been equipped with low, high and high/high indicators, while the existing silo has only low and high levels indicators from the previous demonstration. On the top of the existing silo there are two vent baghouses to prevent dust emissions from the silos during truck unloading. The new storage silo has a pressure equalizing vent to the existing silo. Both silos have manually-operated knife gate valves above their rotary valves. The gate valve on the existing silo is used to isolate the silo material from the weigh feeding equipment. 
Limestone injection into the host boiler may be performed only from the existing feed silo. The LIMB demonstration left behind the following equipment which was utilized in the LIFAC design:

\author{
- Gravimetric Weigh Feeder and Control System \\ - Fuller-Kinyon Pump \\ - Rotary Valve \\ - Flexible Lime Transport Pipe to Boiler \\ - Flow Control and Pressure Relief Valve
}

Limestone from the existing feed silo is fed by the rotary valve to the weigh feeder. The rotary valve is equipped with a variable speed DC-drive which receives an input control signal from the weigh feeder system's controller. The weigh feed consists of a feeder screw and a weigh screw. The feeder screw operates at a constant speed and transports the limestone evenly to the weigh screw. The weigh screw is mounted on load cells and the mass flow rate of limestone is determined by multiplying the weight of material on the screw by its rotation rate.

The limestone is dropped by the weigh screw feeder into the Fuller-Kinyon pump for transport to the boiler. The Fuller-Kinyon pump has a screw which feeds the limestone to a chamber where transport air from the new blower is introduced for pneumatic transport. The maximum design feed rate is $300 \mathrm{lb} / \mathrm{min}$ of limestone at $12 \mathrm{psig}$. The Fuller-Kinyon pump is equipped with an existing vent baghouse and it also serves as an airlock, using the material and check valve to isolate the transport line from the silo. Attached to the pump is a section of flexible hose 8 inches in diameter, which is used to pneumatically convey the pulverized limestone into the boilerhouse and connects to steel piping with replaceable elbows.

\title{
3.2.2 Boiler Injection Area
}

Because of higher limestone flow rates and the large number of injection ports on the boiler, no boiler injection equipment from the LIMB demonstration could be utilized. A new primary splitter was designed which separates the incoming limestone from the Fuller-Kinyon pump into six streams. The primary splitter is equipped with two blowout connections for each of the six streams to clean any plugged material. Each of these six streams has another secondary splitter to achieve the needed twelve streams for every injection location on the boiler. Figure 3-6 shows a plan view of the secondary splitter and boiler injection hoses. 


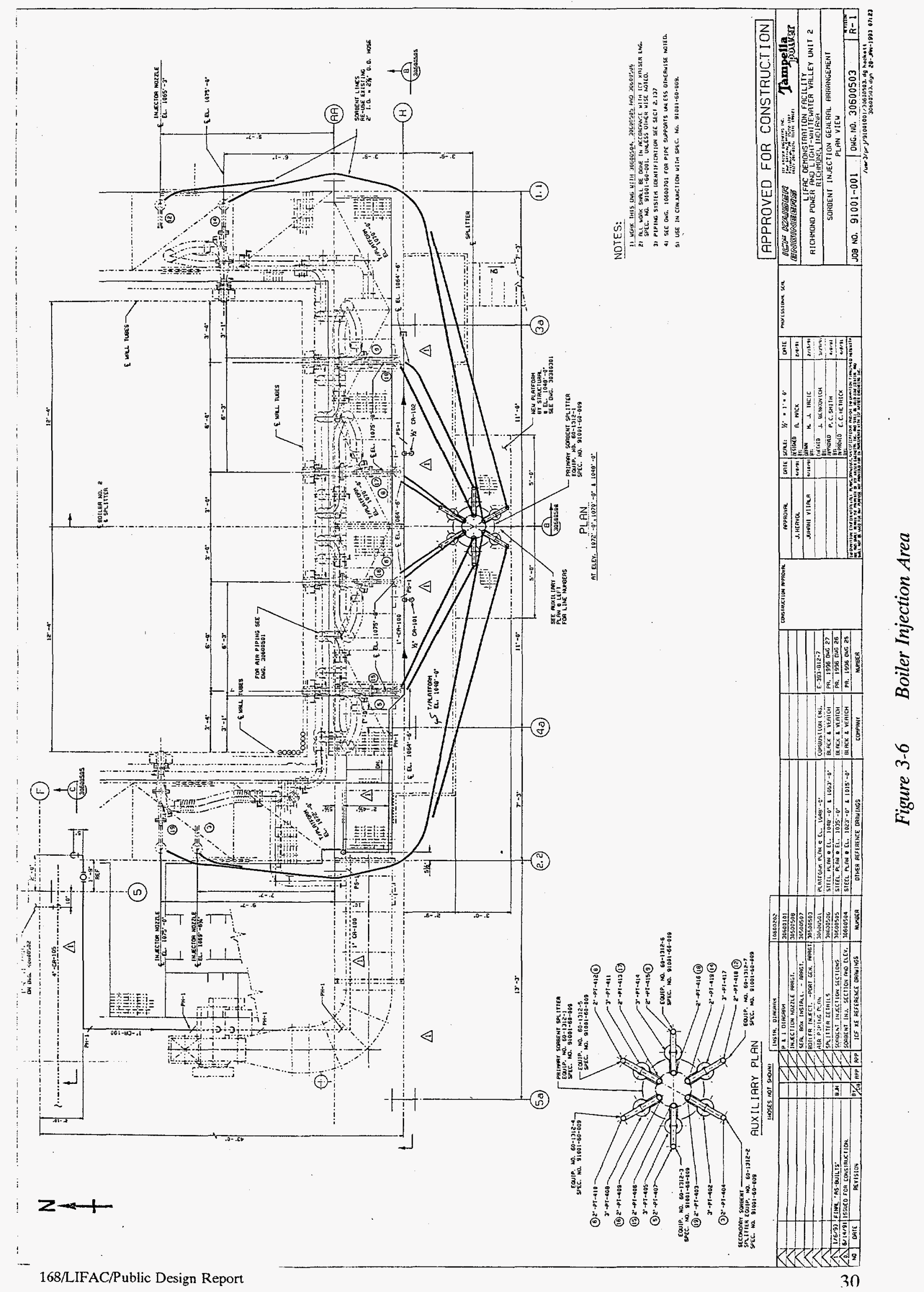


The limestone is moved from the secondary splitters to the boiler injection nozzles via a carbon steel pipe with flexible hose ends to allow for boiler expansion and contraction. There are six injection nozzles on two different levels of the boiler. Each level has four injection ports on the south boiler wall and one on both the east and west walls. Boiler injection port locations are shown in Figure 3-6a. These ports may be used in any combination to allow optimum $\mathrm{SO}_{2}$ removal at different boiler loads.

The injection nozzles are made of stainless steel and include a sight glass to check for limestone pluggage. Mounted to the boilerhouse structural steel, these nozzles may be adjusted vertically to accommodate boiler expansion. The nozzles can also pivot $\pm 15^{\circ}$ to achieve a range of injection angles into the boiler.

A secondary air fan has been provided at the injection location to ensure that the velocity needed for deep penetration and even dispersal of the limestone into the boiler is achieved. This constant speed fan is equipped with a remotely-controlled variable position damper and moves a maximum of 6,700 SCFM of air at 1.73 psig. The air is carried by ductwork to the south boiler wall, where 12 sections of flexible tubing are connected to each injection nozzle. Each section of flex tubing contains one manually-controlled fixed position damper and a second flow controlled damper. The mixing of the secondary air and limestone in the injection nozzle may be viewed through the sight glass.

\subsubsection{Activation Reactor Area}

The reactor area includes all the ductwork, the reactor vessel itself, and the associated systems that handle and humidify the flue gas after the boiler and before it enters the ESP. This proprietary aspect of the process is unique to the LIFAC process; and, therefore, the only equipment that could be reused were three Ingersoll Rand compressors for atomizing air supply.

The reactor vessel, as shown in Figure 3-7, is a vertical chamber in the ductwork where humidification of the flue gas occurs. The vessel is $133 \mathrm{ft}$. high and $28 \mathrm{ft}$. in diameter. It is designed with $3 / 8$-inch thick stainless steel walls to prevent corrosion caused by the precipitation of acid in the humidified flue gas. The vessel has a maximum design pressure of negative 25 inches of water and a temperature of $400^{\circ} \mathrm{F}$. Also included in its design are base slide plates and walkways, with one fixed and one free 


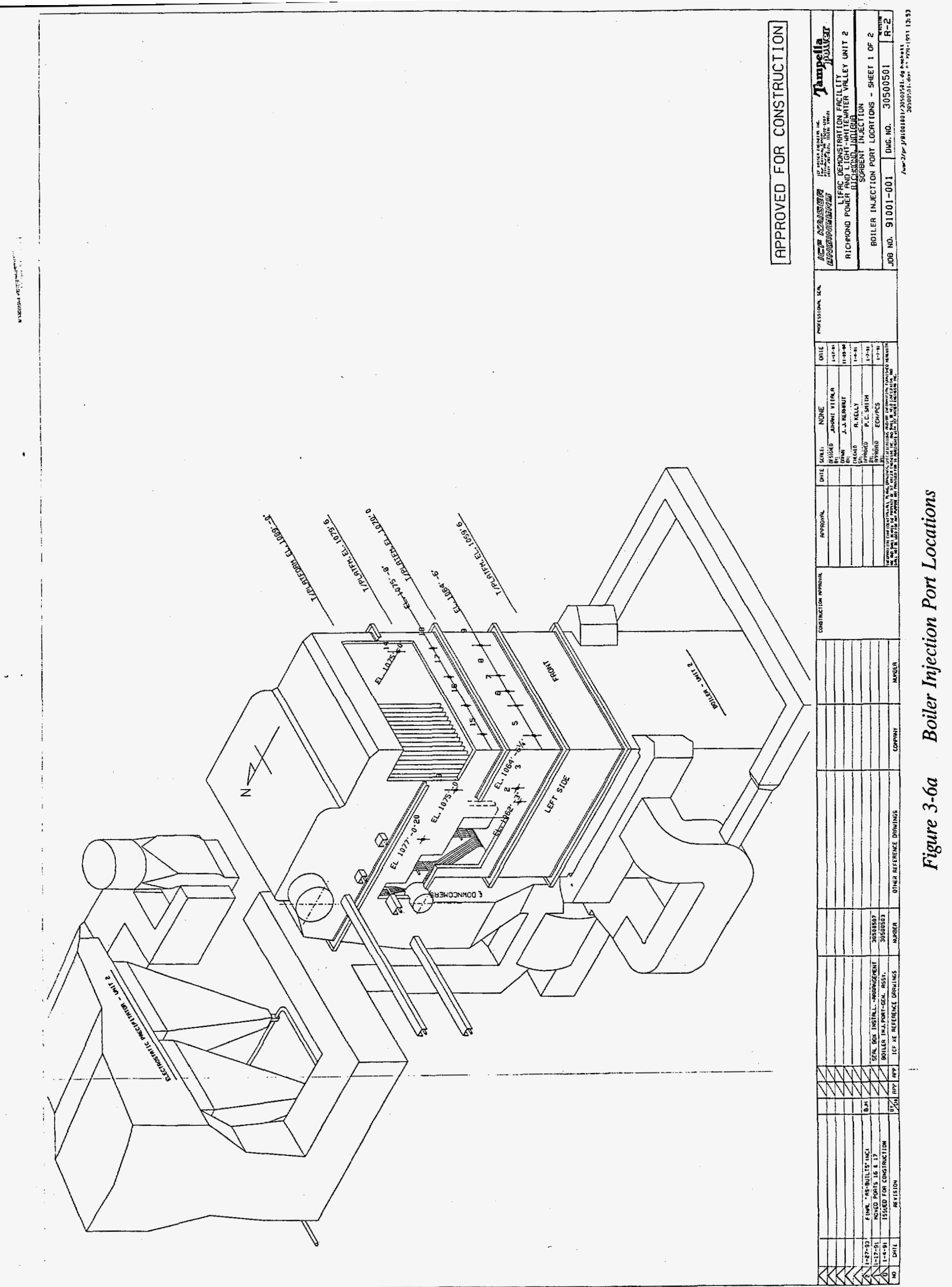



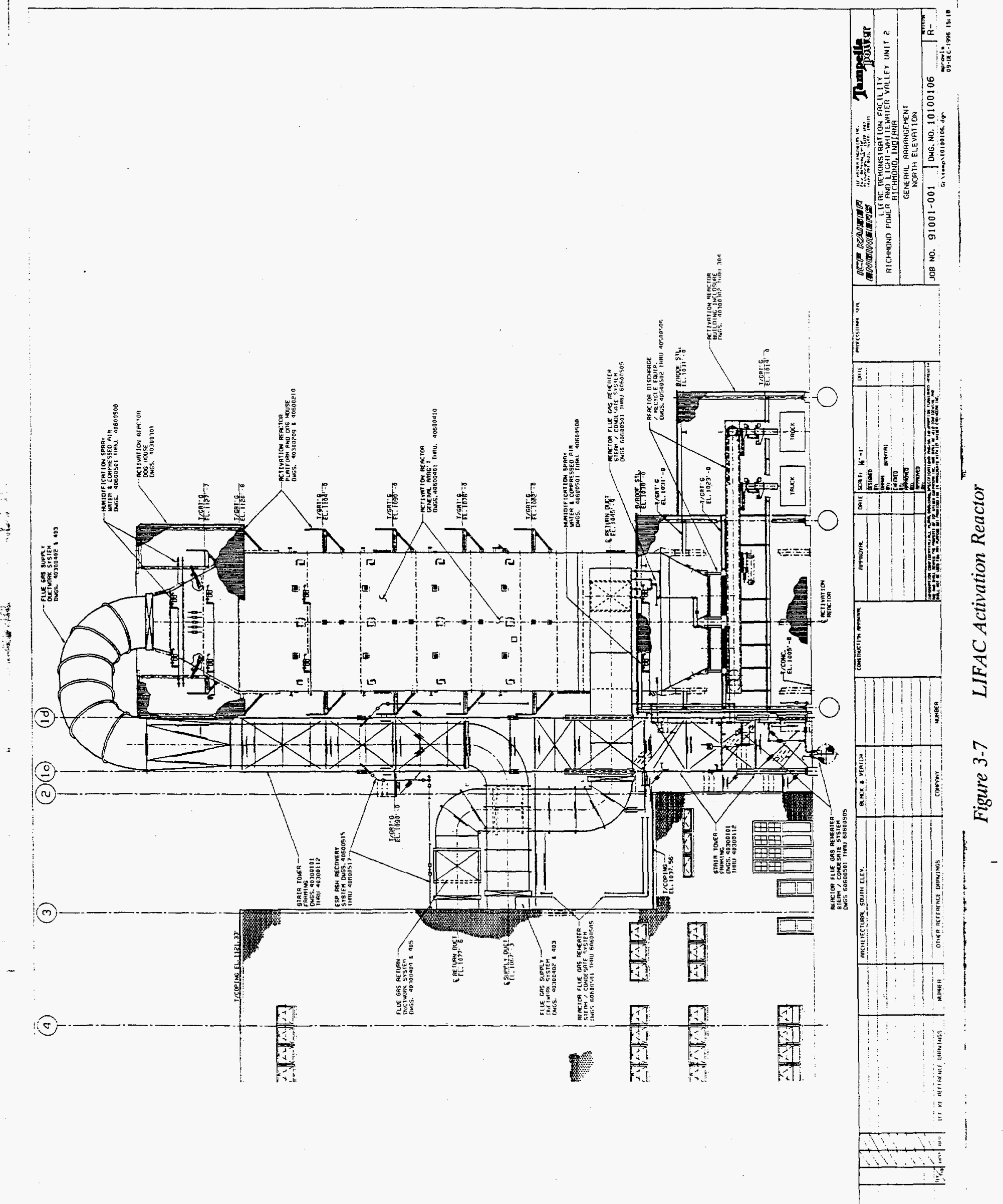

168/LIFAC/Public Design Report 
end to allow for maximum thermal growths of 4.5 inches vertical and 1 inch horizontal. There are also five levels of inspection doors, with six doors on each level, to permit access to the interior of the vessel for visual inspection, flue gas measurements, and repair work.

The bottom section of the reactor vessel interior contains a baffle cone which reduces the crosssectional area and redirects the flue gas flow 180 degrees upward. This allows some of the ash to fall out of the gas stream for collection. At the top outside portion of the baffle cone are three equally spaced outlet duct openings for the exiting flue gas.

Instrumentation on the reactor vessel consists of thermocouples and differential pressure indicators. These instruments create a temperature profile and measure the pressure drop across the reactor vessel. Temperature readings determine the amount of reheat steam necessary to keep the flue gas safely above its saturation temperature.

Flue gas from the boiler is carried to the reactor vessel via a section of bypass ductwork that is tied to the host site's ductwork immediately following the air preheater. The ductwork has been sized according to a maximum gas flow rate of 282,100 ACFM with the Unit No. 2 load at 65 MW. Thermal expansion is compensated for by three expansion joints from 9 to 18 inches in width. Sliding base plates are also employed for lateral ductwork movement. The return ductwork is similar, although there are three outlet openings from the reactor vessel, each having its own expansion joint. The remaining ductwork has six expansion joints, each 12 inches in width. The design of the ductwork includes both turning vanes in the bends to reduce turbulence in the gas flow and 6 inches of insulation to reduce heat loss.

Installed in the three outlet duct legs leaving the reactor are three stainless steel steam reheaters. These reheaters raise the outlet flue gas temperature enough to prevent acid precipitation in the Lodge Cottrell ESP units. The steam supply for the reheaters is from the plant's medium pressure steam system which is at $570^{\circ} \mathrm{F}$ and 246 psi. The maximum combined throughput of the three units at these operating conditions is $9000 \mathrm{lb} / \mathrm{hr}$ of steam. A steam-driven condensate collection system returns the condensate to the plant's system.

In both the inlet and outlet sections of ductwork to the reactor vessel are located a pair of analyzers that take $\mathrm{SO}_{2}, \mathrm{NO}$, and $\mathrm{O}_{2}$ readings, thereby measuring the effectiveness of the reactor vessel in 
reducing emissions. Three flow elements measure the actual amount of flue gas being treated by the reactor, while three differential pressure indicators measure the flow exiting the reactor.

The humidification system requires water and a compressed air supply. Water is provided by a ground level centrifugal pump with maximum operating specifications of 115 GPM and 175 psig. The water supply may come from the plant's river water supply or its chilled water system. A duplex basket-type strainer, installed immediately after the pump, removes any large particulates. The water is then pumped vertically approximately 135 feet to the top of the reactor.

Three Ingersoll Rand helical screw air compressors provide the atomizing air for the humidification. Each compressor has a capacity of 870 ACFM at 125 psig and is located in the limestone storage area. At the top of the reactor in the penthouse, the air and water are combined in dual fluid nozzles. The air distributes the water evenly into the flue gas inside the top of the reactor. Each of the clusters of fluid nozzles has an air-operated scraper to remove ash deposits. The compressors supply the air for the scrapers as well as two sets of vibrators which prevent the buildup of ash on the inside of the reactor vessel.

Instrumentation on the water supply consist of an orifice plate to measure flow and a flow control valve. The flow rate of the water is determined by the temperature of the flue gas leaving the reactor vessel. The air line has a pressure control valve which can be set independent of the flue gas temperature.

The ash separated from flue gas in the bottom of the activation reactor is removed with two bottom drag conveyors. Both of these conveyors have a $22 \mathrm{ton} / \mathrm{hr}$ capacity and are furnished with crushers for larger accumulations of ash which may be dislodged by the reactor's vibrators. The motors on the drag chain and the crusher are reversible in case of jamming. Ash from the bottom drag conveyors is dropped onto a flight transfer conveyor, moving the ash to a pair of double-dump valves which empty into roll off containers for disposal. The double dump valves provide a constant seal to maintain the negative pressure of the flue gas stream through the reactor.

\subsubsection{ESP Recycle Area}

The ash separated from flue gas by the Lodge Cottrell ESP units is removed by gravity and pneumatically recycled directly into the flue gas ductwork immediately preceding the reactor. 
Figure 3-8 provides a mechanical arrangement of the ESP recovery and recycle system used in the LIFAC process. Two of the four ESP hoppers are equipped with variable speed rotary valves which feed two conveying tees where transport air is introduced. A rotary lobe blower provides a maximum of 890 ACFM of air at 7 psig. A manually operated diverter valve in the transport line determines whether the ash is directly recycled or sent to a 10 ton capacity ash surge tank in the reactor area. The surge bin was designed and installed for future use if needed.

\subsubsection{Process Monitoring and Control}

The operation of the LIFAC process is controlled by the PLC (programmable logic controller) using ICF Kaiser proprietary process control software. The process control system is used only for the LIFAC equipment. The operation of the boiler equipment and associated subsystems continue to be controlled by the power plant's original control system and is only monitored by LIFAC's software.

The process control system hardware consists of two identically installed IBM 756 Industrial computers with $19^{\prime \prime}$ VGA color monitors. Both computers are located in the boiler control room. One unit is used to control the entire LIFAC process. A printer for alarm reporting is connected to this computer. The other computer, the monitoring computer, is intended to monitor and collect data. It can also be used as a spare control computer, if necessary.

All the control commands from the control computer to the equipment and feedback data from the equipment and instruments to the computers are transported through three input/output (I/O) racks. Rack No. 1 is for the boilerhouse equipment and instruments; rack No. 2 is for the limestone area equipment and instruments; and rack No. 3 is for the activation reactor area equipment and instruments. The system has a total of 333 input or output points: 29 RTD's, 51 analog inputs, 35 analog outputs, 160 digital inputs, and 58 digital outputs.

\subsection{Host Site Modifications}

\subsubsection{Boiler}

LIFAC boiler modifications were minimal as its design took advantage of the work performed under the LIMB demonstration project. Twelve injection ports into the boiler were required for the limestone system, with seven ports existing from the previous project. The five new openings were 


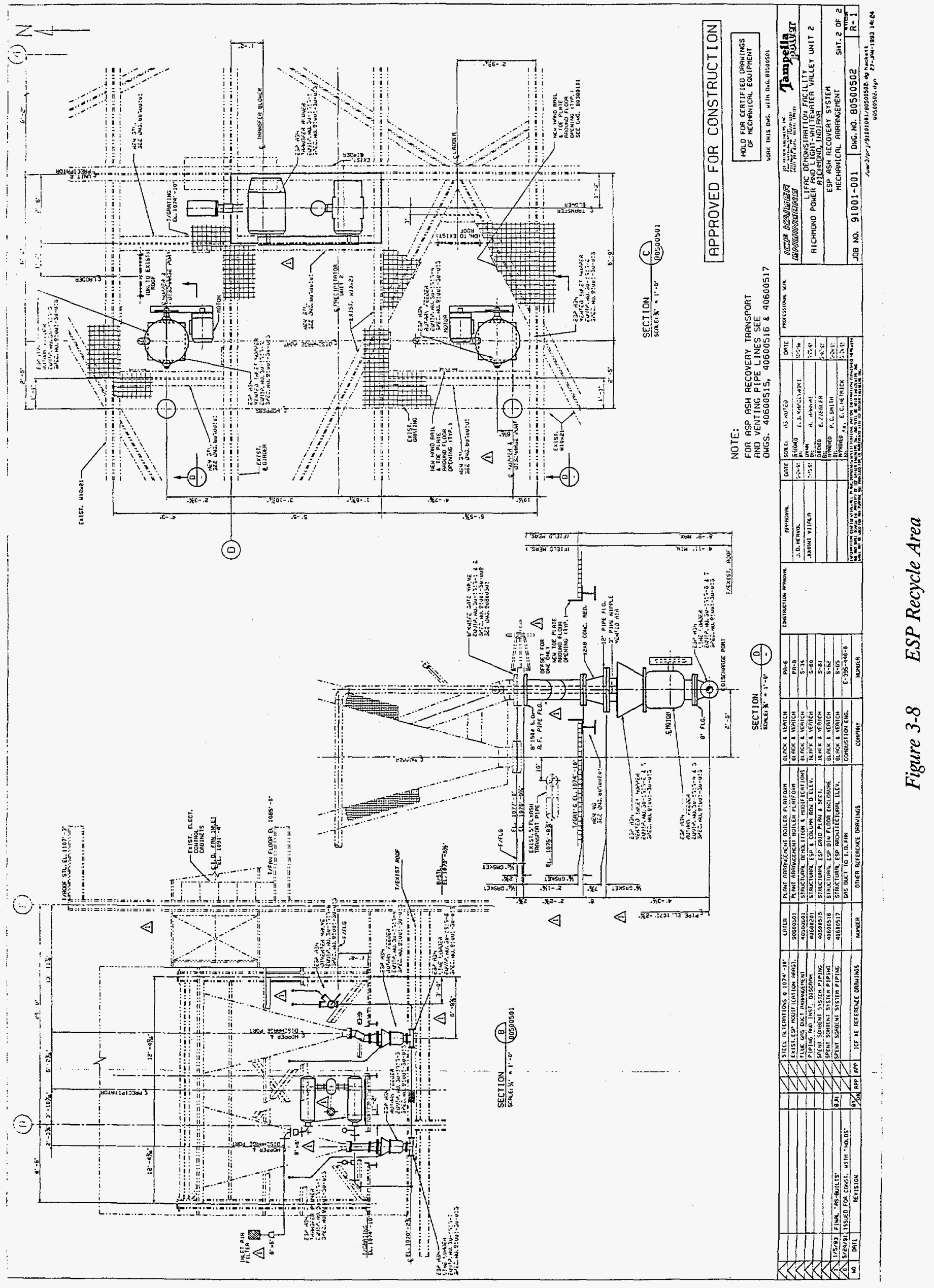


designed with the need to cut and replace only two boiler tubes per opening. The resulting opening is fitted with a mounting frame for the injection nozzle and has bolt holes to accommodate a typical boiler inspection door if necessary. This was the single boiler modification required for LIFAC.

\subsubsection{Ductwork}

The treatment of flue gas in a vertical humidification chamber located outside the boiler house necessitated a modification to the plant's ductwork on Unit No. 2. After the air preheater and before the ESP, two sections of ductwork were added for the gas inlet and outlet to the reactor. Each section has a motor actuated louver-type damper to direct the gas flow. Another motor actuated louver-type damper was installed in the plant's ductwork between the inlet and outlet dampers to eliminate gas bypass of the reactor vessel.

\subsubsection{Utilities}

The utility services required by the LIFAC process consist of plant water, instrument air and steam. Steam is supplied by a tie-in to the plant's medium pressure steam line from Unit No. 2. The connection has a manually operated gate valve at the tap point to isolate the plant's system from LIFAC's. The water supply for humidification has two sources: one is the plant's recirculating water system (between cooling towers and condensers), and the other is river water supply. Both lines have manually operated gate valves for isolation purposes. Desiccant air is required for instrumentation purposes and for the vent filters and baghouses in the limestone area.

\subsubsection{Electrical and Control Systems}

The major modification to the plant's electrical and control systems was the addition of a new ID fan controller. The existing control system used the boiler draft signal to control dampers in the ductwork to maintain the proper boiler pressure. The ID fan runs at a constant speed. The new LIFAC control scheme required the installation of a variable frequency drive (VFD) which controls the ID fan speed according to the boiler draft signal. This increases the capacity of the ID fan, which is needed to compensate for the increased pressure drop caused by the LIFAC system. The design of the new system includes a backup to the plant's original system. The VFD can then be bypassed if it required repair or service during a LIFAC outage. 


\subsubsection{Miscellaneous}

Several other minor plant modifications were included in the design criteria to accommodate LIFAC. In the ESP area for Unit No. 2, pipe spools were included on two of the four ash hoppers for collection of ESP ash for recycling purposes. The pipe spools each have a manually operated knife gate valve to isolate the hoppers from the ash rotary feeders and collection system.

Modifications to the plant's steel work accommodate the design and installation of LIFAC equipment. The ductwork and stair tower steel located east of the power plant is tied to its structural steel by penetration of the outer brick wall in six places. An additional platform was included inside the boilerhouse at the lower injection level to support the secondary air blower. Access to numerous sampling ports and instrumentation was facilitated by new platforms and some extra lighting around the boiler and ductwork inside the power plant. 


\subsection{DETAILED PROCESS DESIGN}

\subsection{Plot Plan and Plant Layout}

Figure 4-1 is the site plan RP\&L's Whitewater Valley utility power plant. The site plan is provided to show the actual arrangement of LIFAC's equipment and building relative to the host facility.

\subsection{Material Balance}

A LIFAC overall block flow diagram is used to show a material balance for the entire desulfurization system. Figure 4-2 also depicts how the LIFAC process streams interact with the host utility. The values shown on the block diagram are based on the design basis presented in Section 3.0 of this report and a peak boiler load of $65 \mathrm{MW}$.

\subsection{Process and Instrumentation Diagrams}

The process and instrumentation diagrams (P\&IDs) of the LIFAC demonstration consist of two drawings. Figure 4-3 is a P\&ID for the instrumentation surrounding the activation reactor and ESP recycle areas; and Figure 4-4 represents the instrumentation for the limestone storage, handling, and injection areas.

\subsection{Process Equipment Arrangement}

A breakdown of the major process equipment for LIFAC was generated by dividing the system into four distinct areas where most of the equipment is located. Table $4 \mathrm{~A}$ shows a listing of all major items involved in the process (refer to Figure 4-6 for item locations). The quantity, manufacturer, capacity, and materials of construction are provided for each item. Horsepowers are also shown for the motorized items which are directly related to the process. Total connected horsepower of the LIFAC system installed at RP\&L is $986 \mathrm{Hp}(736 \mathrm{~kW})$. However, some installed equipment such as the secondary air fan was not been operated during the demonstration. This was based on Tampella's experience and recommendations that it would not have any improvement on performance. Hence, the predicted power consumption of the demonstration is $\approx 486 \mathrm{Hp}(362 \mathrm{~kW})$. The majority of this equipment was constructed using carbon steel. Certain applications required the use of stainless steel for potentially acidic or corrosive environments. 


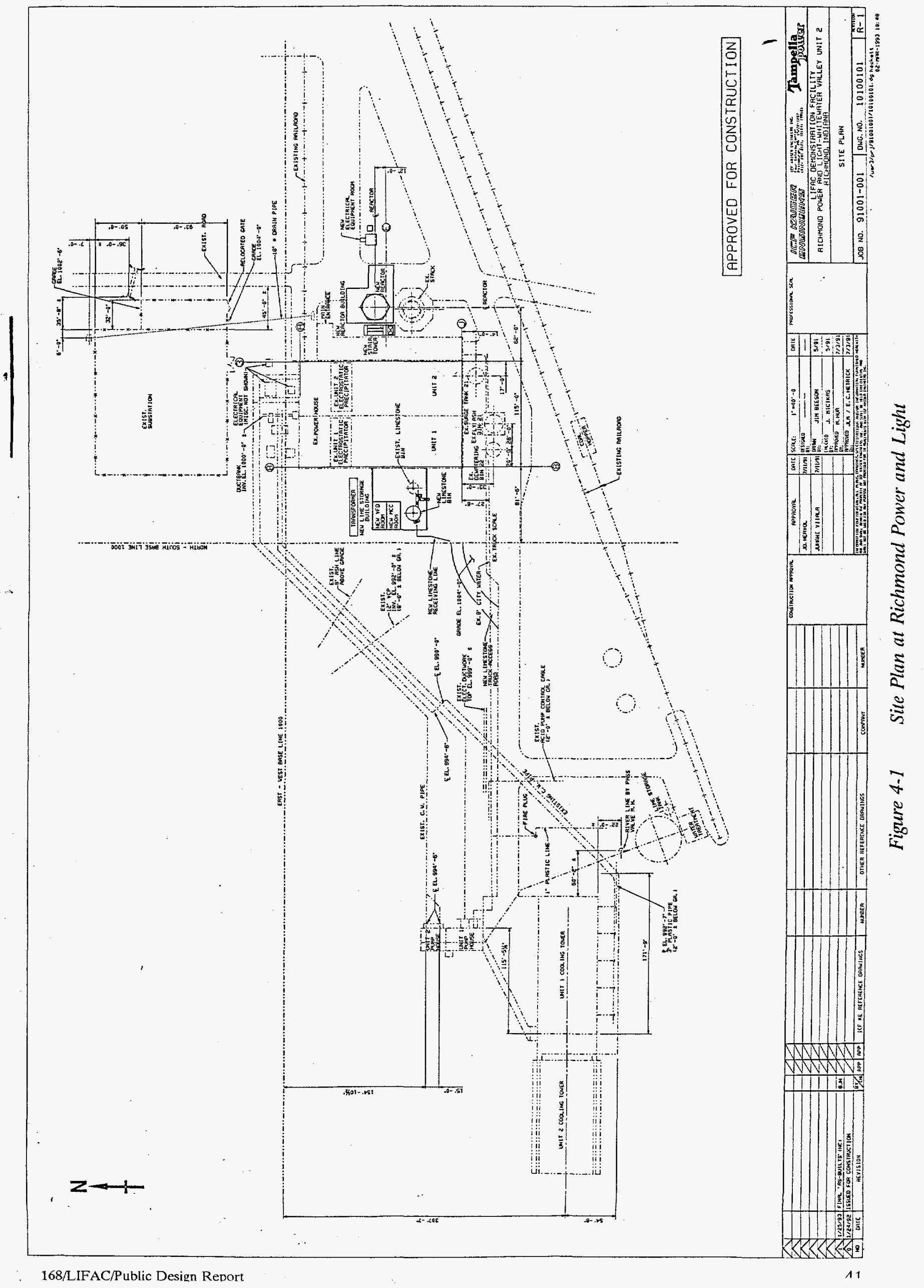


Figure 4-2 LIFAC Overall Block Flow Diagram

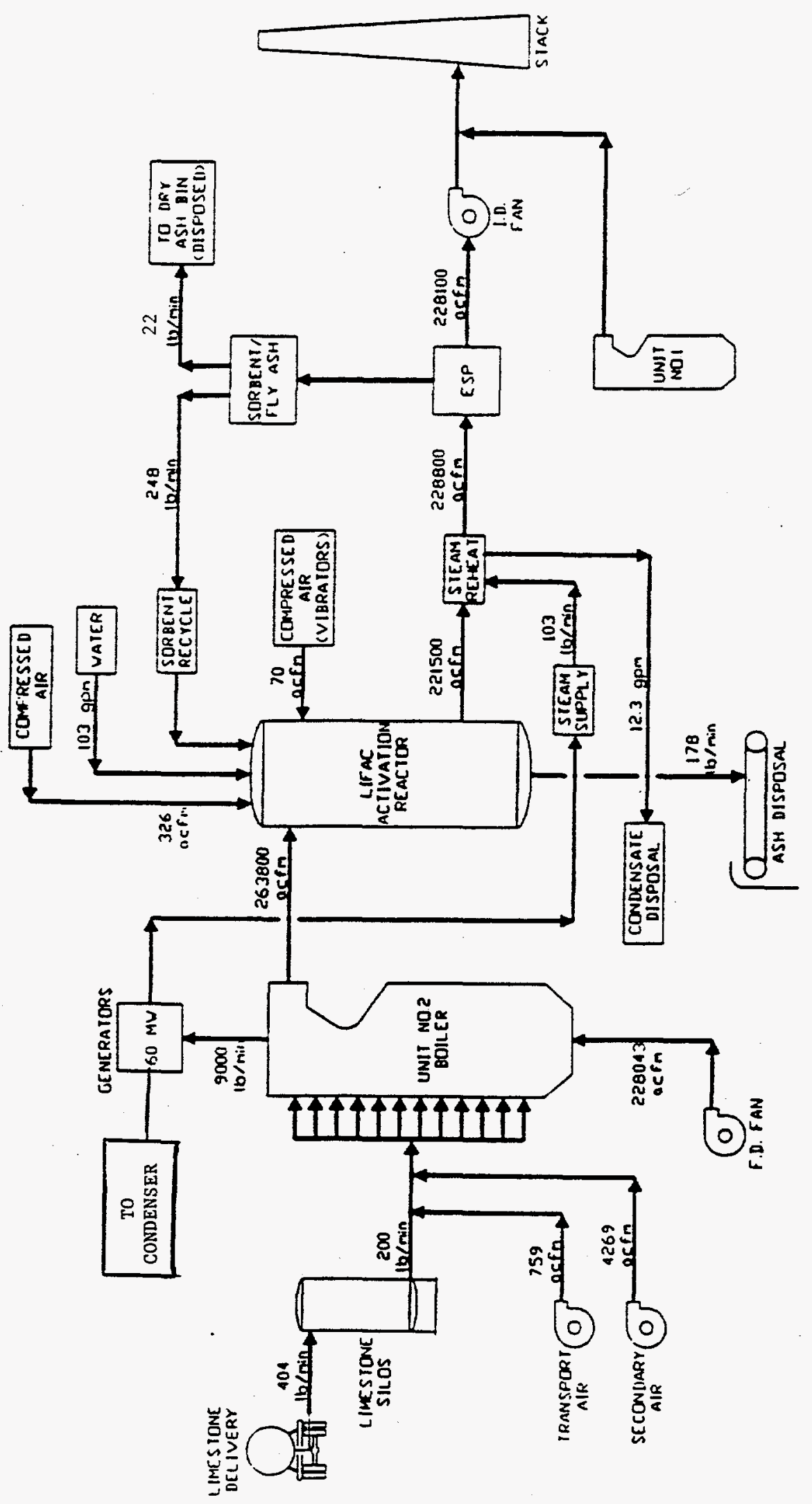




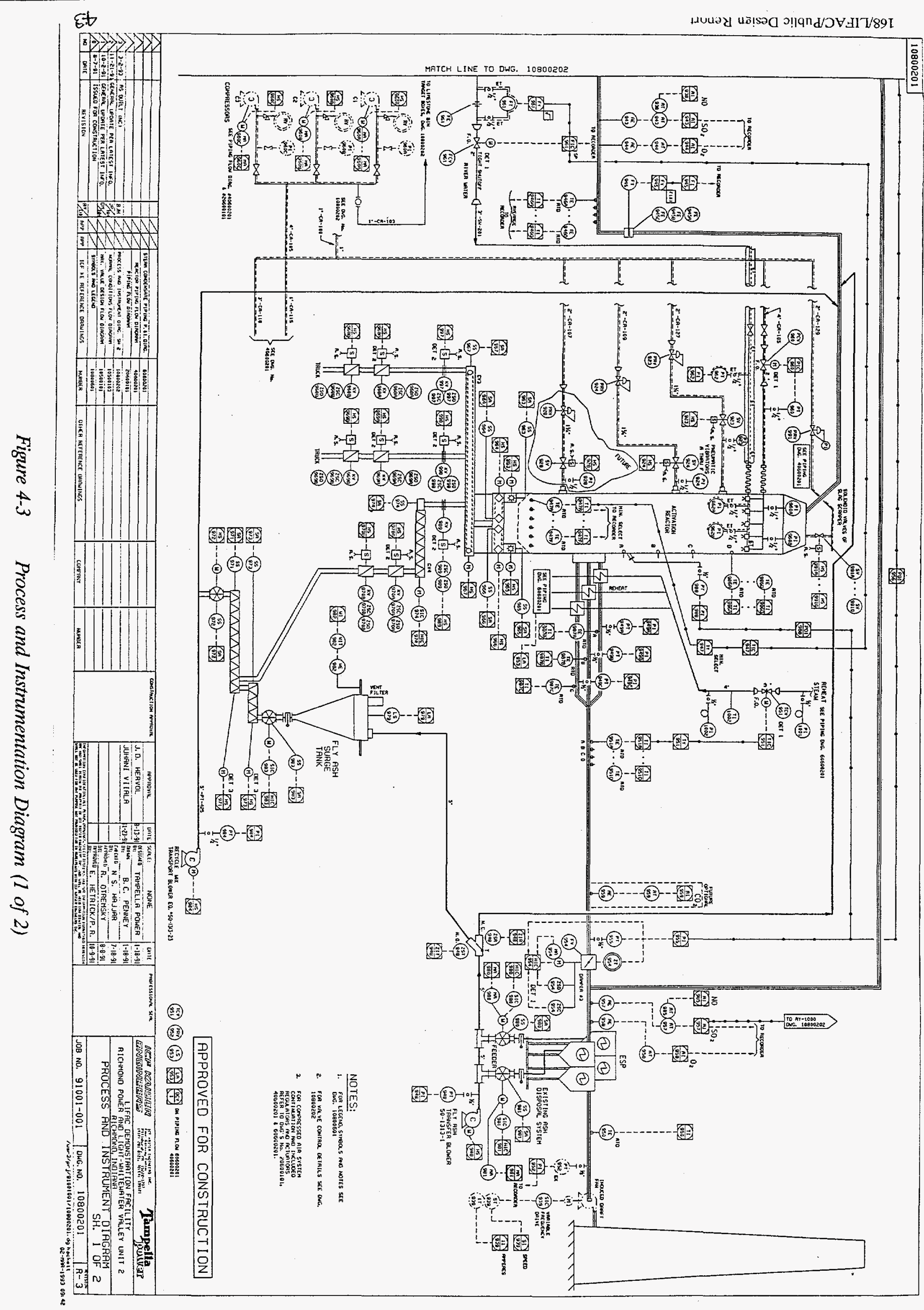


TABLE 4A

LIFAC PROCESS EQUIPMENT AT RP\&L

(Refer to Figure 4-6 for Item Locations)

\begin{tabular}{|c|c|c|c|c|c|c|}
\hline Item \# & Item Name & Quantity & Vendor & Size/Capacity & Total Hp & Materials of Construction \\
\hline \multicolumn{7}{|c|}{ LIMESTONE HANDLING AREA } \\
\hline 1 & Diverter Valve & 1 & Kice & $417 \mathrm{lb} / \mathrm{min}$ & - & Carbon Steel \\
\hline 2 & Storage Silo & 1 & ICF Kaiser/Enerfab & $576,000 \mathrm{lbs}$ & -- & Carbon Steel \\
\hline 3 & Feed Silo & 1 & Existing & $270,000 \mathrm{lbs}$ & $\overline{-}$ & Carbon Steel \\
\hline 4 & Rotary Feeders & 2 & Wm. W. Meyer \& Sons & $400 \& 300 \mathrm{lb} / \mathrm{min}$ & $1 / 5$ & Cast Iron/Carbon Steel \\
\hline 5 & Screw Feeder & 1 & Acrison Inc. & $300 \mathrm{lb} / \mathrm{min}$ & 1 & Stainless Steel \\
\hline 6 & Weigh Feeder & 1 & Acrison Inc. & $300 \mathrm{lb} / \mathrm{min}$ & 0.5 & Stainless Steel \\
\hline 7 & Fuller-Kinyon Pump & 1 & Fuller Company & $300 \mathrm{lb} / \mathrm{min}$ & 25 & $\overline{--}$ \\
\hline 8 & Flow Control Valve & 1 & Fisher Controls & 8" Butterfly & - & - \\
\hline 9 & Limestone Transport Blower & 1 & Roots-Dresser & $1600 \mathrm{acfm}$ & 125 & - \\
\hline \multicolumn{7}{|c|}{ BOILER INJECTION AREA } \\
\hline 10 & Sorbent Splitters & $1 / 6$ & Lenton Industries & $\cdots$ & .. & Carbon Steel \\
\hline 11 & Injection Nozzles & 12 & Nutana Machine LTD & - & -- & Stainless Steel \\
\hline 12 & Secondary Air Fan & 1 & Phelps & $6700 \mathrm{scfm}$ & 100 & -- \\
\hline 13 & Dampers & 4 & Damper Design & - & $\ldots$ & Carbon Steel \\
\hline \multicolumn{7}{|c|}{ ACTIVATION RECTOR AREA } \\
\hline 14 & Feedwater Pump & 1 & Goulds Pumps, Inc. & $115 \mathrm{gpm}$ & 30 & -- \\
\hline 15 & Compressors & 3 & Ingersoll-Rand & 125 psig ea. & 600 & $\cdots$ \\
\hline 16 & Activation Reactor & 1 & ICF Kaiser/Enerfab & $\mathrm{h}=133^{\prime}, \mathrm{d}=28^{\prime}$ & -- & Stainless Steel \\
\hline 17 & Humidification Nozzles & 29 & Spraying Systems Inc. & 30:1.5 gpm (air/water) & - & Stainless Steel \\
\hline 18 & Nozzles Housings & 7 & Nutana Machine LTD & - & $\cdots$ & Carbon Steel \\
\hline 19 & Vibrators & 13 & Navco & $1500 \mathrm{~Hz} @ 60$ psi & -- & - \\
\hline 20 & Flue Gas Reheaters & 3 & Thermatics & $570 \mathrm{~F} / 246 \mathrm{psig}$ & $\ldots$ & Stainless Steel Pipe \\
\hline 21 & Crushers & 2 & Process Equipment & $22 \mathrm{tph}$ & 40 & Carbon Steel \\
\hline 22 & Discharge Conveyors & 2 & Process Equipment & $22 \mathrm{tph}$ & 14 & Stainless/Carbon Steel \\
\hline 23 & Transfer Conveyor & 1 & Process Equipment & $22 \mathrm{tph}$ & 3 & Carbon Steel \\
\hline 24 & Knife Valves & 2 & Process Equipment & $18^{\prime \prime} \times 30^{\prime \prime}$ & -- & Carbon Steel \\
\hline 25 & Slag Gate Valves & 2 & Process Equipment & $18^{\prime \prime} \times 30^{\prime \prime}$ & -- & Carbon Steel \\
\hline 26 & Control Valves air, water, steam) & 3 & Fisher Controls & - & $\cdots$ & - \\
\hline
\end{tabular}




\section{TABLE 4A (Continued)}

LIFAC PROCESS EQUIPMENT AT RP\&L

(Refer to Figure 4-6 for Item Locations)

\begin{tabular}{|c|c|c|c|c|c|c|}
\hline Item \# & Item Name & Quantity & Vendor & Size/Capacity & Total $\mathrm{Hp}_{\mathrm{p}}$ & Materials of Construction \\
\hline \multicolumn{7}{|c|}{ ESP RECYCLE AREA } \\
\hline 27 & Sorbent Recycle Blower & 1 & Sutorbilt & $890 \mathrm{acfm}$ & 40 & $\cdots$ \\
\hline 28 & Rotary Feeders & 2 & Detroit Stoker co. & $10 \mathrm{tph}$ & 1.5 & Cast Iron/Carbon Steel \\
\hline 29 & Gate Valves & 2 & DeZurick & $12 "$ Manual & $\ldots$ & Stainless Steel \\
\hline 30 & Process Monitoring and Control System & 1 & ICF Kaiser/Tampella & -- & - & - \\
\hline
\end{tabular}




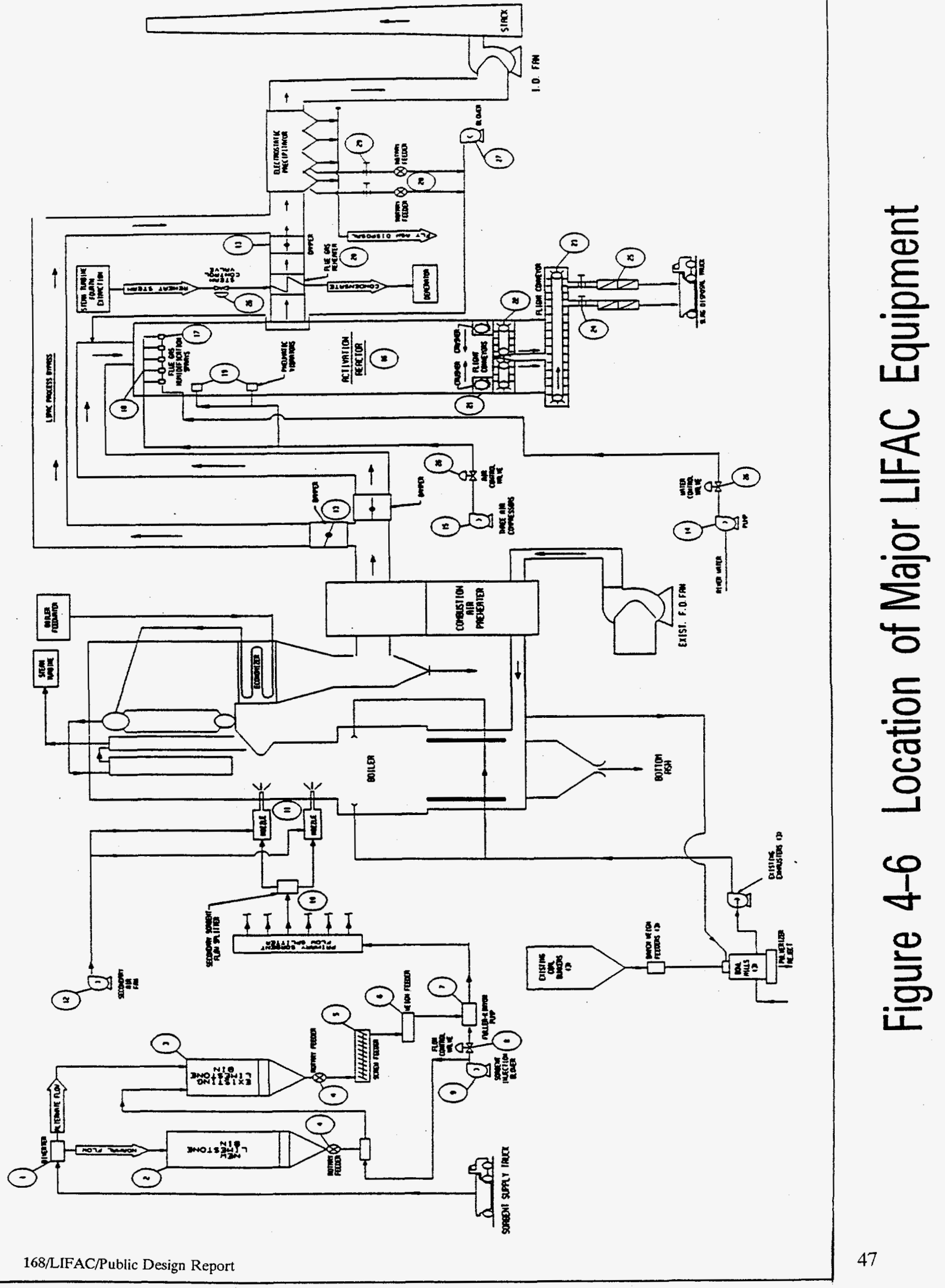




\subsection{Waste Streams and Their Disposal}

Under the Environmental Monitoring, all waste streams impacted by the technology have been monitored before, during and after LIFAC operations. These waste streams include ash from the economizer, LIFAC reactor bottom hopper, ESP hoppers (front and back) and the boiler bottom ash disposal bin. All but the LIFAC ash was and still is disposed by RP\&L by transporting it by truck from the ash disposal bin to an approved landfill. LIFAC ash was trucked off-site separately. It was collected at the bottom of the reactor in dumpsters then hauled to an approved landfill by the LIFAC partnership.

Another waste stream is the water from the boiler bottom which is discharged to the ash disposal bin, and then goes to the power plants pond system. This waste stream was monitored by RP\& at the pond outfall under their NPDES Discharge permit. However, we also monitored this discharge at the ash disposal bin due to the concern of a long residence time through the pond system and inability to verify any impacts. No impact was evident based on the time frame our monitoring was conducted.

Results of all monitoring of ash, feed water, and discharge water are in the Final Report Volume 2: Project Performance and Economics. 


\subsection{PROJECT CAPITAL}

The capital cost breakdown of the LIFAC installation at RP\&L is unique. Since this installation was a retrofit to an existing facility and installed at the site of an earlier FGD demonstration, it is necessary to present a detailed structure of capital spending. Table 5A shows the total capital cost of the LIFAC unit as it was installed. Engineering, reactor fabrication and erection, and structural/ mechanical/piping consumed over half the capital expenditures. The total capital cost of the LIFAC demonstration at RP\&L was approximately $\$ 8,101,000$. Table 5B presents cost to purchase all materials.

Since RP\&L was the site of an earlier FGD demonstration, capital cost savings were experienced. The equipment from the previous demonstration was donated to LIFAC. Each piece of equipment was selected to be utilized based on its operability and reliability for the LIFAC demonstration. This equipment can easily be replaced when LIFAC advances into a commercial operation mode at RP\&L. The reactor ash disposal system was built for demonstration purposes only. Additional capital needs to be spent on ash conveyors and a storage silo before commercial operation. No back-up systems were installed as part of the demonstration. A commercial unit would require some redundancy systems such as a backup water pump, and spare I/O cards for process control system.

The demonstration nature of the project required additional capital expenditure. The LIFAC demonstration program incorporated many testing and measuring techniques. For this reason, additional instrumentation and data collection devices were purchased and utilized. Supplementary sampling ports and man doors were also required for the demonstration in order to inspect and assess the process' impact on the reactor and the ductwork. Five limestone injection ports were installed on the boiler's walls to test several combinations of injection settings.

Additional capital costs also ensued as a result of retrofitting the LIFAC process to an existing facility. Extra engineering, construction, and equipment costs were realized. The following is a breakdown of additional costs encountered as a result of retrofitting:

\section{Layout}

- Erected a building around existing RP\&L limestone storage and handling equipment

- Provided two motor control centers 
TABLE 5A

CAPITAL COST OF THE RICHMOND LIFAC UNIT AS INSTALLED

(BASE YEAR 1993)

\begin{tabular}{|lrr|}
\hline CAPITAL COST & & \\
Equipment \& Materials & $\$$ & 160,000 \\
Limestone Handling \& Storage & $\$$ & 669,000 \\
Activation Reactor \& Ductwork & $\$$ & 67,000 \\
Sorbent Recycle System & $\$$ & 272,000 \\
Electrical/Instrumentation & $\$$ & 255,000 \\
I.D. Fan Upgrade & $\$ \mathbf{1 , 4 2 3 , 0 0 0}$ \\
Total Equipment \& Materials & \multicolumn{2}{|c|}{} \\
Subcontracts: & $\$$ & 324,000 \\
Foundations & $\$ 1,670,000$ \\
Reactor Fab. \& Erection & $\$ 1,569,000$ \\
Structural/Mechanical/Piping & $\$$ & 574,000 \\
Electrical/Instrumentation & $\$$ & 268,000 \\
Insulation \& Cladding & $\$$ & 573,000 \\
Miscellaneous Fabrication & $\$ \mathbf{4 , 9 7 8 , 0 0 0}$ \\
Total Subcontractors & \multicolumn{2}{|c|}{} \\
& $\$ 1,200,000$ \\
Engineering: & $\$$ & 300,000 \\
Management \& Administration: & $\$$ & 200,000 \\
Construction Supervision: & $\$ \mathbf{8 , 1 0 1 , 0 0 0}$ \\
Total Capital Cost &
\end{tabular}




\begin{tabular}{|c|c|c|c|c|c|c|}
\hline $\begin{array}{l}\text { Activity } \\
\text { No }\end{array}$ & Description & Number & Suppller & $\begin{array}{l}\text { P.O } \\
\text { Amount }\end{array}$ & Froght & $\begin{array}{l}\text { Courent } \\
\text { Compitument }\end{array}$ \\
\hline C9006 & Transformers & $91001-1012$ & Richmond Power Light & $(\$ 0 . \infty)$ & $\$ 0.00$ & $(\$ 0.0$ \\
\hline C9003 & Flue Gas Analyzer Parts & $91001-1026 \mathrm{~A}$ & Lear Siegler & $\$ 1,169.30$ & $\$ 33.75$ & $\$ 1,200.05$ \\
\hline C4004 & Expansion Joints & $91001-10278$ & Dynex & $\$ 3,564.00$ & $\$ 77.50$ & $\$ 3,641.50$ \\
\hline C4004 & Isolation Damper & $91001-1027 C$ & Damper Design Inc. & $\$ 6,980.00$ & $\$ 697.70$ & $\$ 7.677 .70$ \\
\hline C4004 & Actuator Parts and Installation & $91001-102 \pi 0$ & Damper Design Inc. & $\$ 2,000.95$ & $\$ 0.00$ & $\$ 2,000.95$ \\
\hline R0012 & ESP Inspection & $91001-1028$ & Lodge-Cottrall & $\$ 4,800.00$ & $\$ 0.00$ & $\$ 4,800.00$ \\
\hline Ro013 & Particulate Emission Modeling & $91001-1033$ & Metecrological Evaluation Ser. & $\$ 4,975.00$ & $\$ 0.00$ & $\$ 4,975.00$ \\
\hline C9014 & Temperature Transmitters & $91001-1035 A$ & Andrews industrial Controls & $\$ 320.00$ & $\$ 16.10$ & $\$ 336.10$ \\
\hline C9012 & Temperature Elements & $91001-1038$ & Ram Sensors & $\$ 2,517.66$ & $\$ 35.16$ & $\$ 2,552.82$ \\
\hline $\mathrm{C} 9013$ & Pressure Indicators & $91001-10434$ & Thermollo Equipment Co. & $\$ 241.78$ & $\$ 11.23$ & $\$ 25301$ \\
\hline C9027 & Flow Element - Flue Gas & $91001-10459$ & Measurement Instruments Ea & $\$ 92200$ & $\$ 0.00$ & $\$ 92200$ \\
\hline Ro014 & Stack Gas Sampling & $91001-1046$ & Keystone Environmental & $\$ 16,200.00$ & $\$ 0.00$ & $\$ 16.200 .00$ \\
\hline R0017 & Sutorbuilt Blower Inspection & $91001-1047$ & Indiana Bulk \& Pneum & $\$ 520.00$ & $\$ 0.00$ & $\$ 520.00$ \\
\hline R0018 & Acrison Weigh Feeder Inspection & $91001-1048$ & Acrison inc & $\$ 2,204.35$ & 50.00 & $\$ 2,204.35$ \\
\hline R0019 & Compressor Inspection & $91001-1049$ & Ingersoll Rand Corp & $\$ 1,099.50$ & $\$ 0.00$ & $\$ 1.099 .50$ \\
\hline R0019 & Compressor Inspection & $91001-10498$ & Ingersoll Rand Corp & $\$ 1,205.20$ & so.00 & $\$ 1,205.20$ \\
\hline R0019 & Compressor Repairs & $91001-10490$ & Ingersoll Rand Corp & $\$ 1,490.26$ & $\$ 0.00$ & $\$ 1,490.26$ \\
\hline R0019 & Compressor Repairs & $91001-10490$ & Ingersoll Rand Corp & $\$ 213.35$ & $\$ 0.00$ & $\$ 213.35$ \\
\hline R0019 & Compressor Repairs & 91001-1049E & Ingersoll Rand Corp & $\$ 1,989.36$ & $\$ 0 . \infty$ & $\$ 1,989.36$ \\
\hline R0020 & Fuller Kinyon Pump Inspection & $91001-1050$ & Fuller Company & $\$ 0.00$ & $\$ 0.00$ & $\$ 0.00$ \\
\hline R0015 & Fuller Kinyon Pump Parts & $91001-1051$ & Fuller Company & $\$ 1,566.00$ & $\$ 35.35$ & $\$ 1,601.35$ \\
\hline R0016 & Corveyor Chain Lubrication & $91001-1052$ & Trbology Tech-Lbe & $\$ 2,410.20$ & $\$ 199.38$ & $\$ 2,600.58$ \\
\hline $\mathrm{R} 0018$ & Air Compressor Parts and Oil & $91001-1053$ & Ingersoll Rand Corp & $\$ 5,266.90$ & $\$ 9.33$ & $\$ 5,276.23$ \\
\hline C2008 & Root's Air Blower & $91001-1055$ & Airtek Inc. & $\$ 13,925.00$ & $\$ 0.00$ & $\$ 13,925.00$ \\
\hline R0021 & Flue Gas Probes & $91001-1056$ & Nap & $\$ 4,823.00$ & $\$ 147.58$ & $\$ 4,970.58$ \\
\hline $\mathrm{R} 0022$ & Calsoration Gases & $91001-1057$ & Velding Supply & $\$ 6,000.00$ & (\$487.80) & $\$ 5,512.20$ \\
\hline P0023 & Signal Isolators & $91001-1058$ & nt Services inc & $\$ 1,638.00$ & $\$ 18.50$ & $\$ 1,656.50$ \\
\hline R0024 & $\mathrm{CO} 2$ and $\mathrm{O} 2$ Analyzers & $91001-1059$ & WWR Scientific & $\$ 85250$ & $\$ 71.10$ & $\$ 923.60$ \\
\hline H0025 & Span Potentiometer & $91001-1060$ & Pressure Measurement & $\$ 60.00$ & $\$ 23.50$ & $\$ 83.50$ \\
\hline P0026 & Analog Input Module & $91001-1061$ & - Supply Co. & $\$ 916.50$ & $\$ 19.25$ & $\$ 935.75$ \\
\hline F10026 & Analog Irout Modulo Repair & $91001-106 \mathrm{AA}$ & Tri-State Supply Co. & $\$ 1,365.00$ & $\$ 19.25$ & $\$ 1.384 .25$ \\
\hline 110027 & Zoro Sprod Switch & $91001-1062$ & Schilbo \& Smith & $\$ 505.00$ & $\$ 26.55$ & $\$ 531.55$ \\
\hline 110028 & Water \& Solid Wuste Al & $81001-1063$ & Anter & $\$ 35,000.00$ & $(\$ 1,002.62)$ & $\$ 33.997 .38$ \\
\hline R0029 & Stack Gas Sampling & $91001-1064$ & Environme & $\$ 10,000.00$ & $(\$ 7,971.98)$ & $\$ 2,028.02$ \\
\hline R0030 & Pilot Operated Solenoid Valve & $91001-1065$ & nbell Co. & $\$ 470.00$ & $\$ 31.45$ & $\$ 501.45$ \\
\hline $\mathbf{R 0 0 3 1}$ & Pressure Gage & $91001-1066$ & M. & $\$ 36.00$ & $\$ 13.70$ & $\$ 49.70$ \\
\hline A0032 & Calibration Adapter Plug & $91001-1067$ & ent and Controls & $\$ 51.00$ & $\$ 13.50$ & $\$ 64.50$ \\
\hline R0034 & Oxygen Monitor Rental & $91001-1068$ & Rentals & $\$ 3,000.00$ & $(\$ 2,668.23)$ & $\$ 331.77$ \\
\hline R0035 & ASCO Replacement Diaphragm & $91001-1069$ & T. F. Campbell & $\$ 33.50$ & $\$ 14.25$ & $\$ 47.75$ \\
\hline R0036 & Sample Containers & $91001-1070$ & ouse Paint Centers & $\$ 2,000.00$ & $(\$ 1,532.00)$ & $\$ 468.00$ \\
\hline R0037 & Control Valve Parts & $91001-1071$ & Equipment Controls & $\$ 277.71$ & $\$ 0.00$ & $\$ 277.71$ \\
\hline $\mathbf{R} 0038$ & Limestone & $91001-1072$ & Group & $\$ 20,903.23$ & $\$ 0.00$ & $\$ 20,903.23$ \\
\hline R0039 & Portable Radios & $91001-1073$ & ications Unlimited & $\$ 1,054.00$ & $\$ 12.00$ & $\$ 1,066.00$ \\
\hline R0040 & VP Replacement Parts & 91001-1074 & It and Control & $\$ 161.93$ & $\$ 0.00$ & $\$ 161.93$ \\
\hline R0041 & Coal \& Ash Analyses & $91001-1075$ & Standard Laboratories & $\$ 20,000.00$ & $(\$ 5,273.84)$ & $\$ 14,726.16$ \\
\hline $\mathrm{R} 0042$ & Switchgear Relays & $91001-1076$ & ssociates & $\$ 184.00$ & $\$ 0.00$ & $\$ 184.00$ \\
\hline $\mathrm{R} 0043$ & Electrical Parts & $91001-1077$ & strial Controls & $\$ 178.01$ & $\$ 41.00$ & $\$ 219.01$ \\
\hline R0044 & Repairs & $91001-1078$ & Lear Siegler & $\$ 82200$ & $\$ 130.70$ & $\$ 95270$ \\
\hline R0045 & Chain Fall & $91001-1079$ & & $\$ 646.60$ & $\$ 15.95$ & $\$ 66255$ \\
\hline R0046 & Transmitter - ID Fan Speed & $91001-1080$ & & $\$ 474.00$ & $\$ 19.25$ & $\$ 493.25$ \\
\hline R0047 & Fittings & $91001-1081$ & olis Valve \& Fitting Co. & $\$ 109.80$ & $\$ 0.00$ & $\$ 109.80$ \\
\hline ROO48 & Sample Port Installation & $91001-1082$ & H.J. Osterfeld & $\$ 3.717 .00$ & $\$ 0.00$ & $\$ 3,717.00$ \\
\hline ค0048 & Injection Piping Installation & $91001-10824$ & H.J. Osterfeld & $\$ 12.902 .00$ & \$o.00 & $\$ 12,932.00$ \\
\hline R0048 & Control Valve Piping Installation & $91001-1082 B$ & H.J. Osterfeld & $\$ 1,245.00$ & 50.00 & $\$ 1,245.00$ \\
\hline R0049 & Chart Paper \& Cartridge & $91001-1083$ & it Sales \& Ser & $\$ 293.85$ & $\$ 3.70$ & $\$ 297.55$ \\
\hline H0050 & Chart Paper \& Pens & $91001-1084$ & Ray Knitter Associates & $\$ 225.75$ & $\$ 5.26$ & $\$ 231.01$ \\
\hline
\end{tabular}


Table 5B, page 2

\begin{tabular}{|c|c|c|c|c|c|c|}
\hline $\begin{array}{c}\text { Activity } \\
\text { No }\end{array}$ & Description & Number & Supplier & $\begin{array}{l}\text { P.O } \\
\text { Armount }\end{array}$ & Frepht & $\begin{array}{l}\text { Cument } \\
\text { Commitment }\end{array}$ \\
\hline R0051 & UFAC Ash Handling & 91001 & Rumpke & $\$ 150,000.00$ & $(\$ 41,072.35)$ & $\$ 108,927.65$ \\
\hline R0052 & Elactrica! Relays & $91001-1086$ & Grant Industrial Controls & $\$ 61.60$ & $\$ 2.24$ & $\$ 63.84$ \\
\hline R0053 & Analyzer Calibration & $81001-1087$ & Lear Siegler & $\$ 2,051.00$ & $\$ 0.00$ & $\$ 2,051.00$ \\
\hline 80054 & Certified Smoke Reader & $91001-1088$ & Crawtordsville EL \& P & $\$ 525.73$ & $\$ 0.00$ & $\$ 525.73$ \\
\hline R0055 & Opacity Monitoring \& Consulting & $91001-1089$ & Mostardi-Platt Associates, inc & $\$ 18,104.76$ & $\$ 0.00$ & $\$ 18,104.76$ \\
\hline R0055 & Opacity Monitoring \& Consulting & $91001-1089 C$ & Mostardi-Platt Associates, inc & $\$ 18,142.00$ & $\$ 0.00$ & $\$ 18,142.00$ \\
\hline R0055 & Opacity Monitoring \& Consulting & $91001-10890$ & Mostardi-Platt Associates, Inc & $\$ 103,940.00$ & $(\$ 64,684.60)$ & $\$ 39.255 .40$ \\
\hline R0056 & Sorbent Injection Hose & $91001-1090$ & Specialty Hose Corp & $\$ 2,504.70$ & $\$ 117.35$ & $\$ 2,622.05$ \\
\hline R0057 & MOHRINC & $91001-1091$ & Crane Rental & $\$ 1,240.00$ & $(\$ 322.00)$ & $\$ 918,00$ \\
\hline R0058 & Ross Hills Controls & $91001-1092$ & VFD Service & $\$ 1,500.00$ & $(\$ 1,500.00)$ & $\$ 0.00$ \\
\hline R0059 & Limestone Supply & $91001-1093$ & Cosmos Cement & $\$ 160,000.00$ & $(\$ 19,495,50)$ & $\$ 140,504.50$ \\
\hline ก10060 & Pepair Alr Conditioning Sys & $91001-1094$ & Fuller Engineering Se & $\$ 361.05$ & $\$ 0.00$ & $\$ 361.05$ \\
\hline n0060 & Hopair Air Conditioning System & $91001-10944$ & Fuller Engineering Services & $\$ 1.192 .50$ & $\$ 0.00$ & $\$ 1,192.50$ \\
\hline R0060 & Repair Air Conditioning System & $91001-1094 \mathrm{~B}$ & Fuller Engineering Services & $\$ 500.00$ & $(\$ 500.00)$ & $\$ 0.00$ \\
\hline R0061 & Repair Pressure Transmitter & $91001-1095$ & Rosemount, inc & $\$ 800.00$ & $(\$ 682.17)$ & $\$ 117.83$ \\
\hline R0062 & Water Control Valve & 91001-1096 & Equipment \& Controls & $\$ 3,363.00$ & $\$ 0 . \infty 0$ & $\$ 3.363 .00$ \\
\hline R0063 & Signal Isolators & $91001-1097$ & uments & $\$ 73200$ & $\$ 11.98$ & $\$ 743.98$ \\
\hline R0064 & Signal Isolator/Convertor & $91001-1098$ & Engineering & $\$ 205.00$ & $\$ 3.58$ & $\$ 208.58$ \\
\hline R0065 & Pneurnatic Tugger Rental & 91001-1099 & id Associates & $\$ 4,000.00$ & $(\$ 2,758.84)$ & $\$ 1,241.16$ \\
\hline R0066 & Electro-Pneumatic Transducer & $91001-1100$ & M.S. Jacobs \& Assoc. lnc. & $\$ 407.00$ & $\$ 4.29$ & $\$ 411.29$ \\
\hline R0067 & Roof Repairs & $91001-1101$ & Mid-Miami Rooling & $\$ 3,196.50$ & $\$ 0.00$ & $\$ 3,196.50$ \\
\hline R0068 & Flue Gas Peheat Study & $91001-1102$ & Black \& Veatch & $\$ 2,920.00$ & $\$ 0.00$ & $\$ 2,920.00$ \\
\hline R0069 & Filter Cartridges & $91001-1103$ & Oynamic Air Corn. Systems & $\$ 67200$ & $\$ 42.08$ & $\$ 714.08$ \\
\hline R0070 & Pneumatic Tugger Rental & $91001-1104$ & F\& M Supply & $\$ 3,000.00$ & $\$ 1.712 .25$ & $\$ 4.712 .25$ \\
\hline B0072 & ATD Temperature Detectors & $91001-1105$ & er Bonfili & $\$ 28200$ & $\$ 68.90$ & $\$ 350.90$ \\
\hline R0073 & Particle Size Analyses & $91001-1106$ & Penn State University & $\$ 15,000.00$ & $(\$ 12,220.80)$ & $\$ 2,779.20$ \\
\hline R0075 & Proximity Limit Switches & $91001-1107$ & Denko Engineering & $\$ 864.00$ & $\$ 22.00$ & $\$ 886.00$ \\
\hline ค0076 & Waste Disposal & $91001-1108$ & Chemical Waste Manzegement & $\$ 50,000.00$ & $(\$ 19,718.26)$ & $\$ 30,281.74$ \\
\hline R0077 & High Pressure Cleaning & $91001-1109$ & envices & $\$ 6,185.50$ & $\$ 3.592 .50$ & $\$ 9,778.00$ \\
\hline R0078 & Solenoid Valves & $91001-1110$ & Tristate Supply & $\$ 328.00$ & $\$ 15.00$ & $\$ 343.00$ \\
\hline R0079 & isformer & $91001-1111$ & Horn & $\$ 48.75$ & $\$ 3.27$ & $\$ 52.02$ \\
\hline R0080 & Irverter Hepair & $9100 t-1112$ & Horner Electric & $\$ 856.10$ & $\$ 39.45$ & $\$ 895.55$ \\
\hline R0081 & Weigh Feeder Repairs & $91001-1113$ & & $\$ 31.26$ & $\$ 27.35$ & $\$ 58.61$ \\
\hline RoOBt & Weigh Feeder Repairs & $91001-11134$ & Acrison & $\$ 2,971,10$ & $\$ 0.00$ & $\$ 2,971.10$ \\
\hline $\mathrm{R} 0071$ & Project Computer & $91001-16073$ & 2000 & $\$ 1,996.00$ & $\$ 425.22$ & $\$ 2,420.22$ \\
\hline 80002 & Sleel, Mechanical, Piping Inst. & $|91001-3002-6|$ & Enerfab inc & $\$ 19,627.64$ & $\$ 0.00$ & $\$ 19,627.64$ \\
\hline 80002 & Steel, Mechanical, Piping Inst. & $91001-3002-7$ & Inc & $\$ 14,026.23$ & $\$ 0.00$ & $\$ 14,026.23$ \\
\hline R0002 & Steel, Mechanical, Piping Inst. & $91001-3002-8$ & Enerfab Inc & $\$ 518.74$ & $\$ 0.00$ & $\$ 518.74$ \\
\hline R0002 & Steel, Mechanical, Piping Inst. & $91001-3002-9$ & Enerfab Inc & $\$ 1,640.94$ & $\$ 0.00$ & $\$ 1,640.94$ \\
\hline R0003 & Mechanical Repairs & $91001-3004$ & Oberle \& Associates & $\$ 8,500,08$ & $(\$ 5,639.00)$ & $\$ 2,870.08$ \\
\hline 70001 & Electrical Instrumentation & $91001-3005$ & Cummins Electric & $\$ 8.785 .61$ & $\$ 0.00\}$ & $\$ 8,785.61$ \\
\hline A0001 & Electrical \& Instrumentation & $91001-3005$ & Cummins Electric & $\$ 14,927,18$ & $\$ 0.00$ & $\$ 14,927.18$ \\
\hline $\mathrm{R} 0007$ & Insulation and Lagging & $91001-3006$ & Kramig Co. & $\$ 2,380.58$ & $\$ 0.00$ & $\$ 2,380.58$ \\
\hline R0033 & Stack Sampling & 91001-3007 & Keyslone Environmental Res. & $\$ 18,497.31$ & $\$ 0.00$ & $\$ 18,497.31$ \\
\hline B0074 & Reheal Duct Installation & $91001-3008$ & Kennedy Tank \& Mfg. Co. & $\$ 12,153.00$ & so.00 & $\$ 12,153.00$ \\
\hline & & & TOTAL PEAIOD II & $\$ 864,603.05$ & $(\$ 179,700.54)$ & $\$ 684,90251$ \\
\hline
\end{tabular}

Indicales a New or Revised Commitment in the Current Month 
- Modified ESP ductwork with vanes and baffle plates

- Erected additional stairs in boiler house

- Extensively routed ductwork to/from reactor

\section{Construction}

- Some work was performed only during boiler outages

- Rerouted some existing plant piping

- Rerouted some existing plant electrical cables

- Cleanup after construction (paving, grass, painting, etc.)

\section{Equipment}

- Repaired, replaced, and calibrated existing RP\&L limestone storage and handling equipment

- Installed additional limestone silo for increased capacity

- Installed a stand-alone process control system

- Installed a VFD to increase ID fan efficiency

- Added an instrument air compressor for LIFAC instrumentation

- Installed moisturizing screw conveyor on ESP ash disposal silo

- Changed ESP fly ash removal from hydroveyor to blower-operated vacuum system

Fabrication of LIFAC's process elements was performed both in the shop and on-site. Prefabrication was initiated by the subcontractors at their respective facilities prior to shipment. Most of the structural steel applications were prefabricated including: reactor support, stair tower, reactor building, and the limestone building. All steel structures were provided with bolted connections. The steel was prepainted; only touchup painting was required at the site. It was necessary for certain sections of ductwork to be assembled in the shop. Ducts were composed of flanges for easy bolt connections. No on-site painting of the ductwork was necessary.

On-site fabrication was performed on the grounds of RP\&L before erection. Most of the activation reactor vessel was assembled at RP\&L. The humidification (top) and discharge (bottom) sections of the LIFAC reactor were prefabricated, cut in half, shipped to the site, then assembled before installation. Each circular section of the reactor was welded on-site from three arcs, each one-third 
of the total circumference. The reactor and ductwork were fitted with insulation and cladding prior to erection. The remaining process equipment was shipped to the site installation.

Table 5C presents estimated costs of the existing equipment which was incorporated into the LIFAC Project. (Note that these costs represent what it would cost to purchase and install these items as part of the project, if they were not existing).

TABLE 5C

\title{
ESTIMATED COSTS FOR EXISTING EQUIPMENT INCORPORATED INTO THE LIFAC PROJECT
}

\author{
Existing equipment \\ 125-ton Storage Silo $\$ 106,400$ \\ Limestone Feeding System $\quad \$ \quad 694,600$ \\ Two Vent Baghouses $\$ \quad 20,400$ \\ TOTAL COSTS $\$ \mathbf{8 2 1 , 4 0 0}$
}

Also, the additional cost incurred because this was a demonstration project is estimated at $\$ 534,100$. This basically includes $75 \%$ of the environmental costs which is included under engineering in Table 5A with the required monitoring, and also approximately $25 \%$ of project management/ administration. 


\subsection{PROCESS OPERATING COST}

\subsection{Fixed Operating Cost}

During the two-year demonstration period, the project required a surplus of operating and test personnel. Two additional operators per shift were required for the test phase of the project, while a unit in commercial operation would require a limited operating staff. Minor maintenance tasks were performed by the test team and the RP\&L maintenance crew. Major repairs or modifications were executed by subcontractors. The LIFAC process was demonstrated over short operation periods, from one day to three weeks of testing. Except for the onset of unexpected repair, maintenance costs were expected to be low during the 2800 hours of the demonstration period. Table 6A shows the estimated annual fixed operating and maintenance cost of the RP\&L LIFAC unit in continuous operation. The total fixed O\&M cost was approximately $\$ 581,200$.

\subsection{Variable Operating Cost}

Variable operating cost includes all the commodities necessary for process operation. The major variable cost, which are presented in detail in Table $6 \mathrm{~B}$, consist of limestone, waste disposal, energy, and water. These values are based on operating the power plant at full load (60 MW). Limestone delivery contracts for the demonstration were short-term with the two suppliers located 150 and 250 miles from Richmond. This type of contract and distance from the site induce higher limestone prices. However, local limestone suppliers do not have the capacity or required quality for the demonstration. The price of limestone ranged from $\$ 26 /$ ton to $\$ 37 /$ ton, whereas the average commercial value of limestone is about $\$ 15 /$ ton. Ash disposal cost was expected to vary during testing. Disposal cost is dependent upon the waste management company and landfill used. The price was expected to range between $\$ 11 /$ ton and $\$ 35 /$ ton.

Energy costs involve auxiliary power consumed by the process equipment and the reheating of exiting flue gas using medium pressure steam. The total connected horsepower for LIFAC is $736 \mathrm{~kW}$. However, some equipment was not used continuously for the demonstration, and the estimated average consumption of auxiliary power was approximately $362 \mathrm{~kW}$. Steam was used to reheat the flue gas prior to entering the ESP. Nearly $100 \mathrm{lb} / \mathrm{min}$ of medium pressure was needed to increase the gas temperature $35^{\circ} \mathrm{F}$. Water was provided by RP\&L from the Whitewater River or plant recirculation system. 
TABLE 6A

ESTIMATED ANNUAL FIXED OPERATING COST UNDER CONTINUOUS OPERATION

\begin{tabular}{|c|c|c|}
\hline \multicolumn{3}{|c|}{ ANNUAL FIXED OPERATING COSTS, CONTINUOUS } \\
\hline \multicolumn{3}{|l|}{ Operating Labor Cost Details: } \\
\hline Number of Operators Per Shift & 2 & \\
\hline Number of Shifts Per Week & 4.2 & \\
\hline \multirow[t]{2}{*}{ Operating Pay Rate $\$ /$ Hour } & 25 & \\
\hline & & Cost, $\$ /$ Year \\
\hline Total Annual Operating Labor Cost & & $\$ 499,200$ \\
\hline Total Annual Maintenance Labor Cost & & $\$ 25,000$ \\
\hline Total Annual Maintenance Material Cost & & $\$ 50,000$ \\
\hline Total Annual Adminstrative and Support 1 & ost & $\$ 7,000$ \\
\hline Total Annual Fixed O\&M Cost & & $\$ 581,200$ \\
\hline
\end{tabular}


TABLE 6B

ESTIMATED VARIABLE OPERATING COST UNDER NORMAL CONDITIONS

\begin{tabular}{|c|c|c|c|c|}
\hline \multicolumn{5}{|c|}{ VARIABLE OPERATING COSTS (65 MW, NORMAL FLOW) } \\
\hline Commodity & Unit & \$/Unit & Quantity/hr & $\$ / h r$ \\
\hline Limestone & tons & 35.00 & 6 & 210.00 \\
\hline Reheat Steam & lbs & 0.003 & 6,180 & 18.50 \\
\hline Water & gals & 0.00 & 6,180 & 0.00 \\
\hline Auxiliary Power & $\mathrm{kWh}$ & 0.02 & 360 & 7.20 \\
\hline Ash Removal & tons & 17.00 & 5.4 & 91.80 \\
\hline \multicolumn{4}{|c|}{ Total Variable Operating Cost } & 327.50 \\
\hline \multicolumn{4}{|c|}{ Total Planned Operating Hours for Demonstration } & 2,800 \\
\hline
\end{tabular}




\subsection{Startup and Checkout Cost}

The startup and checkout period was initiated shortly after baseline testing in September of 1992. Since the process is easy to start up and shut down, all checkouts were performed by operating the process for short periods of time. Most shakedown activities were accomplished by LIFAC personnel. Some equipment, especially the remaining EER units (from the LIMB tests), needed the attention of manufacturers' representatives for calibration or repair. RP\&L maintenance also helped to expedite the checkout process. The approximate startup cost of the LIFAC process is shown in Table $6 \mathrm{C}$. The startup cost of the demonstration was about $\$ 200,000$.

An extra set of gas analyzers were rented for calibration and verification. The limestone feeding system was calibrated by continuously filling a large bucket with limestone and observing the change in silo weight. It was discovered during the startup phase that some items needed modifications due to the following problems: the ID fan's variable frequency drive failed several times; the flue gas dampers were sticking; the steam reheat condensate return system was inoperable; and the water control valve and ESP recycle rotary feeders were the wrong type.

The process control system was calibrated via the process computers in the RP\&L control room while LIFAC was operating at reduced flows.

Several training classes were held for RP\&L personnel to educate them on the various principles and operating procedures of the LIFAC process. 
TABLE 6C

ESTIMATED STARTUP COST OF THE LIFAC SYSTEM

\begin{tabular}{lc}
\hline \hline \multicolumn{1}{c}{ Startup Cost Element } & Cost, $\$$ \\
\hline Operating Labor Cost & $\$ 110,000$ \\
\hline Maintenance and Materials Cost & $\$ 38,500$ \\
\hline Administrative and Support Cost & $\$ 38,500$ \\
\hline Commodity Cost: & $\$ 6,250$ \\
\hline Limestone & $\$ 5,400$ \\
\hline Reheat Steam & $\$ 0$ \\
\hline Water & $\$ 1,600$ \\
\hline Power & $\$ 4,250$ \\
\hline Ash Removal & $\$ 204,500$ \\
\hline TOTAL & $\mathbf{2}$ \\
\hline \hline
\end{tabular}


The LIFAC FGD system has a relatively low overall cost due to the simplicity of the process and low operation costs. The drawbacks of the process are a low sorbent utilization rate $(\sim 40 \%)$ and a moderate $\mathrm{SO}_{2}$ removal rate ( 75 to $85 \%$ ). The limestone sorbent used with LIFAC is cheaper and easier to handle than other, more efficient FGD processes. Although LIFAC units have been installed with new boilers on two occasions, it is primarily installed as a retrofit. Existing power plants and industrial facilities do not have the rigid emissions limits which are associated with new facilities. Also, existing plants have limited space available for FGD systems. A LIFAC unit can be installed with minimum space requirements and removes up to $85 \%$ of the $\mathrm{SO}_{2}$ from a plant's emissions. The LIFAC process is easy to operate. The process monitoring system is located in the plant's control room. Controls can be incorporated into the plant's panels or isolated from plant operations.

LIFAC systems have been designed for coal-fired boilers ranging from 25 to $350 \mathrm{MW}$. The number of units needed is dependent upon the amount of flue gas generated and the size of the ESPs at the facility. A $300 \mathrm{MW}$ boiler will require two LIFAC units to treat the existing gas stream, due to the units diameter and humidification.

Limestone injections into the furnace may affect certain boiler operations such as soot blowing frequency. However, its impact on the host is minimal. Limestone injection rate is dependent on the sulfur content of the combustion coal.

The ash by-product generated in the desulfurization process does not require additional treatment before dumping at a landfill. Thus, waste handling and disposal are less expensive. The by-product is dry and may need to be moistened to eliminate any dust concerns. The ash from some commercial installations has been used for concrete block production and in the mining industry.

There are several LIFAC units in operation on boilers burning various types of coal, from low Btu lignite to high Btu bituminous coal. A listing of LIFAC installation worldwide is presented in Table 7A. The first full-size LIFAC installation treating high sulfur $(2.5 \%)$ coal emissions is the RP\&L demonstration facility.

It is believed that LIFAC units become a less competitive option for power plant $>500 \mathrm{MW}$. Based on an internal marketing study conducted by LIFAC North America, there are approximately 850 
TABLE 7A

LIFAC INSTALLATIONS WORLDWIDE

\begin{tabular}{||l|c|c|c|c|c|c||}
\hline \multicolumn{1}{|c|}{ Client - Plant } & Country & Delivery Year & Boiler Size & $\begin{array}{c}\text { Amount of Flue Gas } \\
\text { to LIFAC Reactors }\end{array}$ & $\begin{array}{c}\text { SO } \% \\
\text { Removed }\end{array}$ & $\begin{array}{c}\text { Ca/S } \\
\text { Molar Ratio }\end{array}$ \\
\hline $\begin{array}{l}\text { Imatran Voima, Inkoo 4/1 } \\
\text { Pilot }\end{array}$ & Finland & 1986 & $250 \mathrm{MW}$ & $20 \%$ & $76 \%$ & -- \\
\hline Nestre, Kulloo & Finland & 1986 & $3 \mathrm{MW}$ & $100 \%$ & $77 \%$ & 2 \\
\hline Imatran Voima, Inkoo 4/2 & Finland & 1988 & $250 \mathrm{MW}$ & $50 \%$ & $75-80 \%$ & 2.5 \\
\hline Prommashimport, Baikal & Russia & 1988 & $45 \mathrm{MW}$ & $100 \%$ & -- & -- \\
\hline $\begin{array}{l}\text { Imatran Voima, Inkoo 4/1 } \\
\text { Saskatchewan Power, } \\
\text { Poplar River }\end{array}$ & Finland & 1989 & $250 \mathrm{MW}$ & $50 \%$ & -- & -- \\
\hline $\begin{array}{l}\text { Richmond Power \& Light, } \\
\text { Whitewater Valley }\end{array}$ & USA & 1990 & $300 \mathrm{MW}$ & $50 \%$ & -- & -- \\
\hline $\begin{array}{l}\text { Saskatchewan Power, } \\
\text { Shand 1 }\end{array}$ & Canada & 1992 & $330 \mathrm{MW}$ & $50 \%$ & -- \\
\hline $\begin{array}{l}\text { Kostamuksha, Mining } \\
\text { Combine }\end{array}$ & Russia & 1994 & $230 \mathrm{MW}$ & $100 \%$ & -- \\
\hline Xiaguan Power Station & China & 1995 & $125 \mathrm{MW}$ & $100 \%$ & -- & - \\
\hline
\end{tabular}


(less than $500 \mathrm{MW}$ ) potential units where the LIFAC technology could be applicable. It could also be noted that as long as emissions credits are around $\$ 200$ per ton of $\mathrm{SO}_{2}$ removed, the LIFAC units are not economically feasible. Emissions credits need to be in the $\$ 400 /$ ton range to make LIFAC marketable. 


\subsection{REFERENCES}

1. US DOE Contract No. DE-FC22-90PC90548, "LIFAC Demonstration at Richmond Power and Light Whitewater Valley Unit No. 2," March 1992.

2. LIFAC Process Evaluation Test Plan, LIFAC Sorbent Injection Desulfurization Demonstration Project presented to U.S. Department of Energy, Pittsburgh Energy Technology Center, Pittsburgh, PA, August 1992.

3. Rosse, J.; Hervol, J.; Viiala, J.; Koskinen, J.; Patel, J.; and Huffman, I; "LIFAC Flue Gas Desulfurization," presented March 1992. 


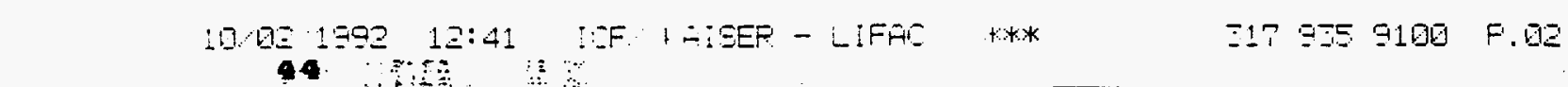

Branen Cost

10446

Laเ. No.

$09 / 28<82$

Precia -

Date Samoled

Sampied By

\section{Youratings}

औy

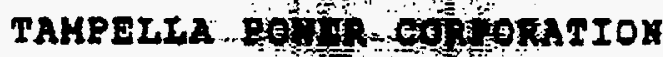

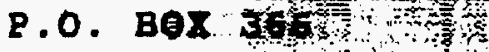

RICHMOID, If Strat

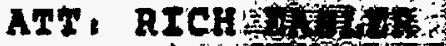

Asto

ite.

it

$+1=$

(n)

a

SAMPLE IDENTIFICATTON

$1+$
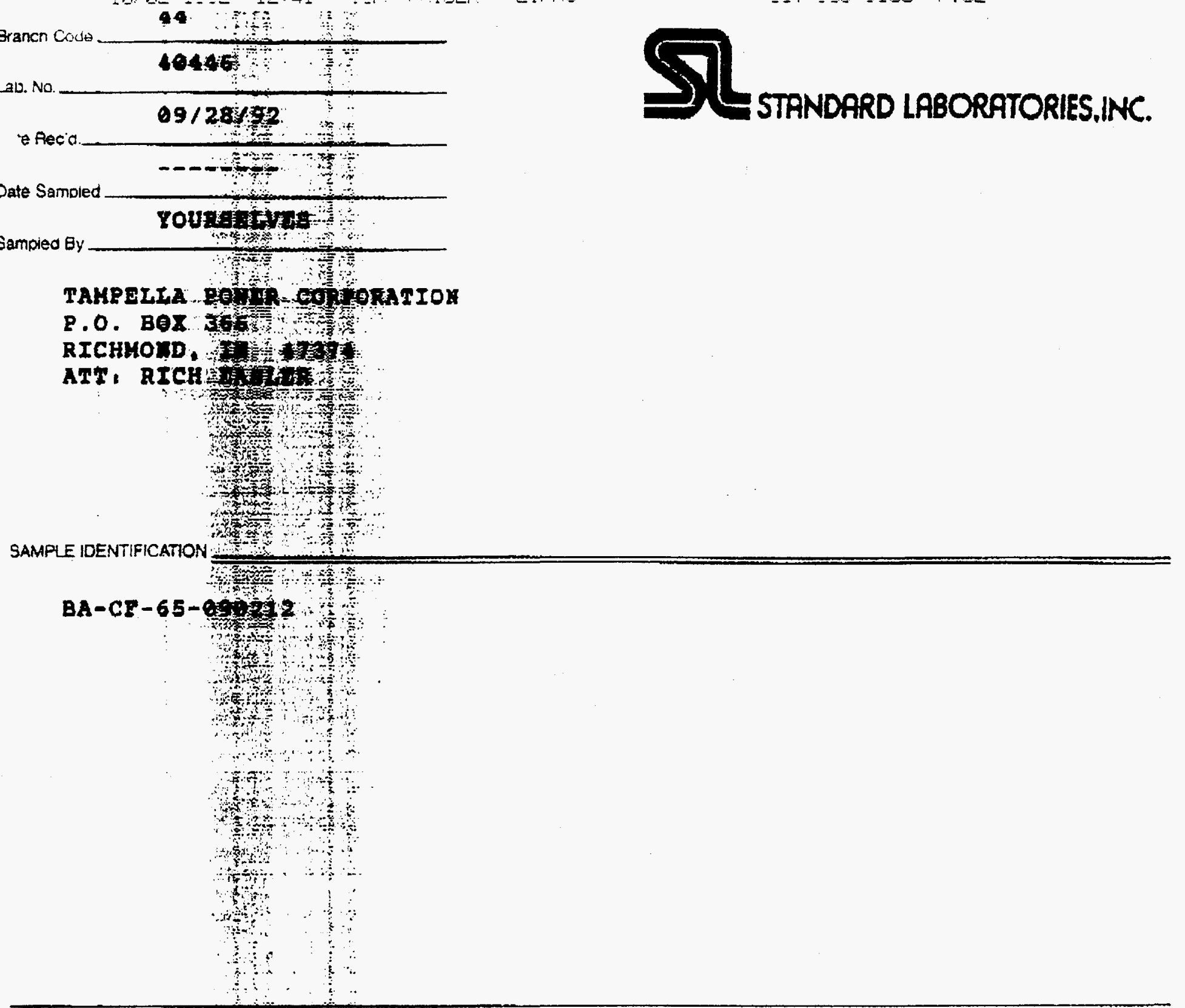

\begin{tabular}{|c|c|c|c|c|c|c|}
\hline & \%o Moighus: & Han & is Volatile & os Fixed Carbon & B.TU./LB & $\%$ Sulfur \\
\hline As Recid. & 13.48 & 苑.90 & $x \times x \times$ & $\mathbf{x x x y}$ & 11343 & 2.38 \\
\hline Dry Basis & $-\infty--\infty$ & 10.24 & $\mathbf{X X X X}$ & $\overline{X X X X}$ & 13049 & 2.73 \\
\hline
\end{tabular}

M-A-Free

14537

YOTE: ZXXX EDTEAYPS AHALYSIS WAS NOT PERYORMED

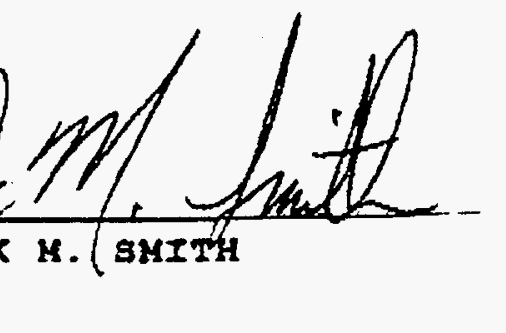




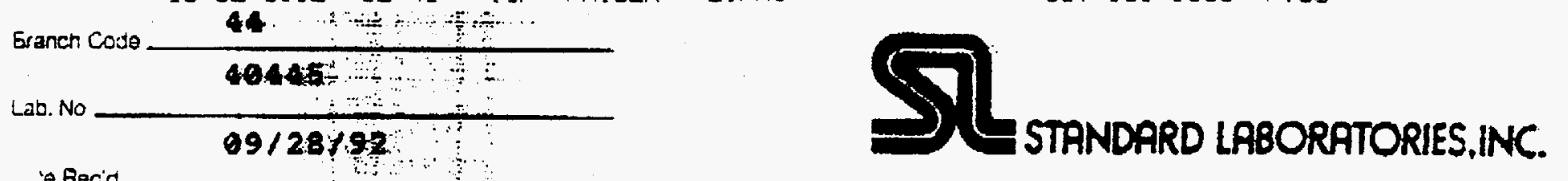

Date Sampled

Sampled By

Youreblyta

का

TAMPELIA FETEOOETORATION

P.0. BOX 36)

RICHHOND DT $=4004$

ATT, RICH, I,

tis

$+4$

,

SAMPLE IDENTIFICATION

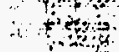

\section{9}

$+4$

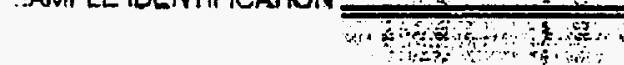

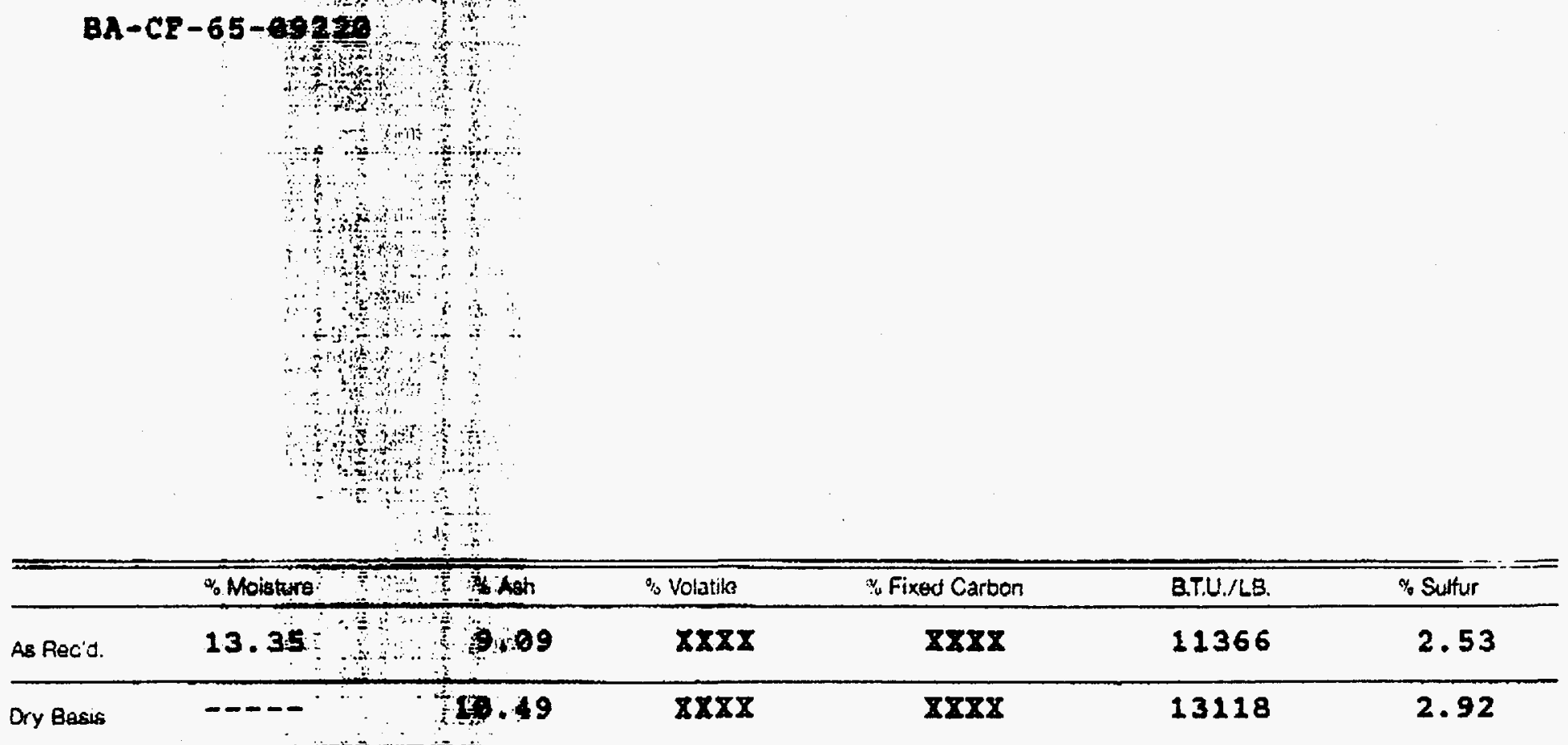




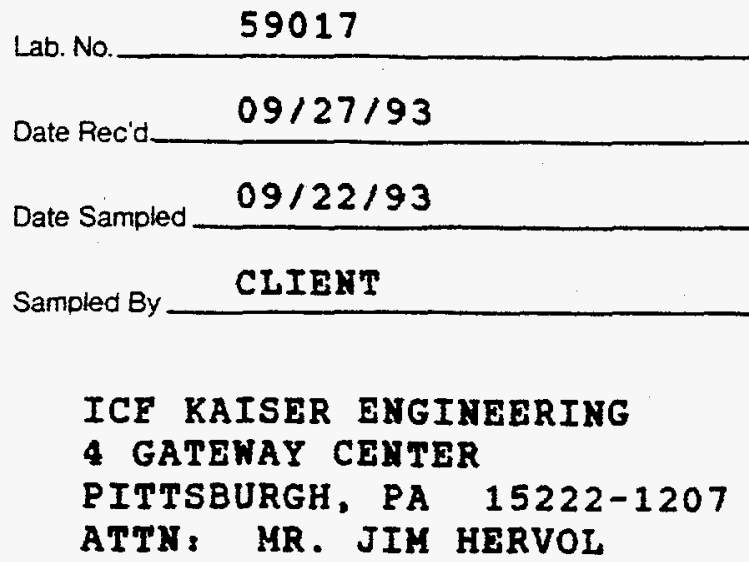

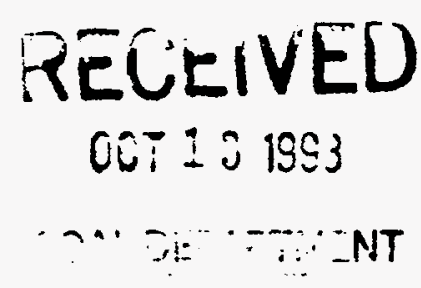

SAMPLE IDENTIFCATION

\author{
COAL FEEDER \\ TEST $\$ 1$ \\ GRIMDABILITY MOISTURE $=2.548$
}

DATE REPORTED: $10 / 08 / 93$

\begin{tabular}{lrrrrrr}
\hline \hline & \% Moisture & \% Ash & \% Volatile & \% Fixed Carbon & B.T.U./LB. & \% Sulfur \\
\hline As Rec'd. & 11.74 & 10.78 & 33.36 & 44.12 & 11345 & 2.24 \\
\hline Dry Basis & $-1 .-$ & 12.21 & 37.80 & 49.99 & 12854 & 2.54 \\
\hline \begin{tabular}{l} 
M-A-Free \\
\hline
\end{tabular} & & & & 14642 & \\
\hline
\end{tabular}

FREE SWELLING INDEX : XXXX

$\begin{array}{lccc}\text { ASH FUSIOY TBMPERATURES } & \text { (DEG E) } & \text { REDUCING } & \text { OXIDIZIYG } \\ \text { INITIAL } & & 2100 & 2525 \\ \text { SOFTEYING } & 2235 & 2550 \\ \text { HEMISPHERICAL } & 2355 & 2570 \\ \text { FINAL } & & 2510 & 2610\end{array}$

HARDGROVE GRINDABILITY INDEX, 54

NOTE: XXXX INDICATES AKALYSIS WAS NOT PEREORMED FOA YOUR PROTECTION THIS DOCUMENT HAS BEEN PRINTED ON CONTROLLED PAPER STOCK. NOT VALD IF ALTERED.

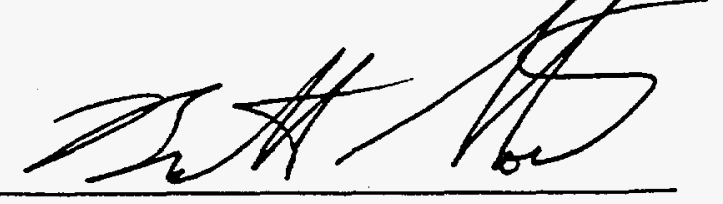


Lab. No

$09 / 27 / 93$

Date Rec'd

$$
09 / 22 / 93
$$

Date Sampled

CLIBYT

Sampled By

ICE RAISER BMGIUEBRIRG

- GATENAY CBUTBR

PITTSBURGH, PA 15222-1207

ATTI: HR. JIH HERVOL

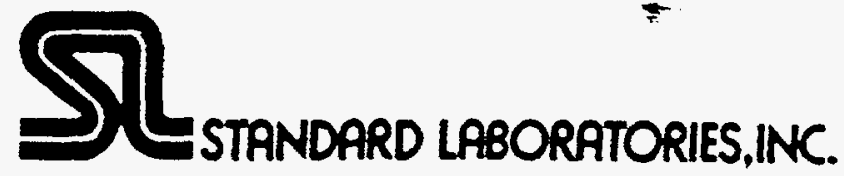

1530 ॥. CULLEX AVBMUE

EVAHSVILLE, IY 47715

\section{SAMPLEBAL FEBDER \\ TBST $\$ 1$}

ARSEIIC - 84.4 ug/g ASH BASIS

DATE REPORTED: $10 / 08 / 93$

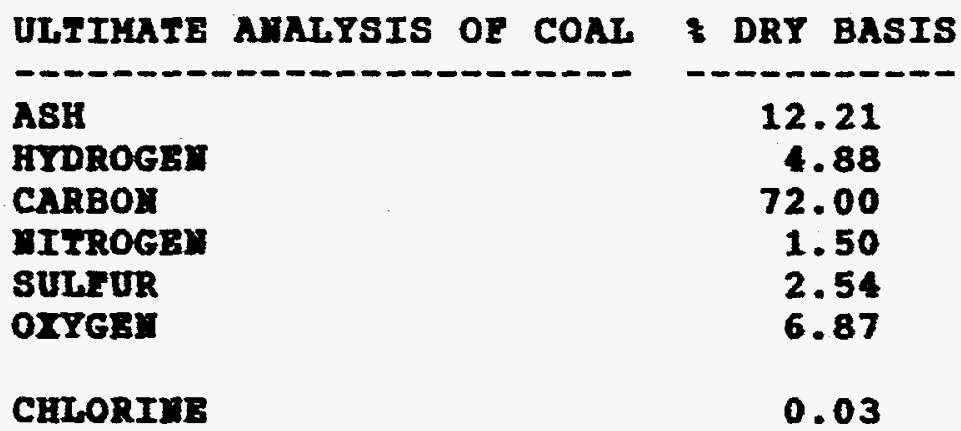

MIYBRAL AMALYSIS OF ASH I IGIIED BASIS

SIIICON DIOXIDB (SIOP)

ALUMILUY OXIDE (AL203)

TITAHIUM DIOIIDE (TIO2)

CALCIUH OXIDE (CAO)

POTASSIUY OXIDE (K20)

MAGTBSIUA OXIDE (HGO)

SODIUH OXIDE (nA20)

PHOSPEORUS PEITOXIDE (P205)

FERRIC OXIDE (FE203)

SULPUR TRIOXIDE (SO3)

UHDETERHIMED

BASE/ACID RATIO,

LBS OF ASH/HILLION BTU:

SLAG VISCOSITY:

FOULIYG IKDEX:

SLAGGIHG IXDEX,

SILICA VALUE:

F ARALI AS MA20,

$$
\begin{array}{r}
\text { BTU: } \\
2550 \\
0.0846 \\
0.7676 \\
70.9282 \\
0.1759
\end{array}
$$

48.60

22.88

1.12

2.48

1.74

0.76

0.28

0.24

16.68

2.42

2.80

0.3022

9.50

DEG F. T250 POISE

TYPE: LON

TYPE \& MEDIUH 
Lab. No. 59018

Date Rec'd $09 / 27 / 93$

Date Sampled $09 / 22 / 93$

Sampled By CLIFHI

\section{A. CULLEM AVENUE} EVANSVILLE, IX 47715

ICE KAISER ENGINEERING

4 GATEWAY CENTER

PITTSBURGH, PA 15222-1207

ATTI, HR. JIH HERVOL

SAMPLE IDENTIFICATION

COAL FEEDER

TEST $* 2$

GRINDABILITY MOISTURE $=2.527$

DATE REPORTED: $10 / 08 / 93$

\begin{tabular}{llccccc}
\hline & \% Moisture & \% Ash & \%.Volatile & \% Fixed Carbon & B.T.U./LB. & \% Sul \\
\hline As Rec'd. & 12.52 & 10.39 & 33.75 & 43.34 & 11322 \\
\hline Dry Basis & & & & & & \\
\hline M-A-Free & & 11.88 & 38.58 & 49.54 & 12942 & 2.4 \\
\hline \hline
\end{tabular}

FREE SWELLIKG INDEX : XXXX

ASH FUSION TEMPERATURES (DEG E) REDUCIKG OXIDIZIKG

INITIAL

SOFTENIKG

HEMIS PHERICAL

FINAL

2150

2240

2580

2385

2610

2480

2620

2635

HARDGROVE GRINDABILITY INDEX : 53

NOTF, $X X X X$ IMDICATES ANALYSIS WAS YOT PERFORMED 


Lab. No. $\frac{59018}{09 / 27 / 93}$
Date Rec'd $\frac{09}{09 / 22 / 93}$
Date Sampled $\frac{09}{\text { CLIENT }}$
Sampled By

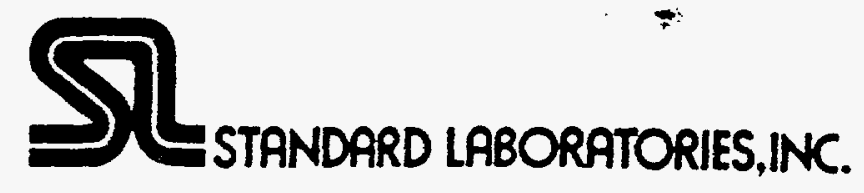

\author{
1530 ฯ. CULhBH AVEMUE \\ BVAMSVILLE, II 47715
}

SAMPLE ID:

COAL FEEDER

ICP RAISER EMGIHEBRIHG

TEST $\$ 2$

- GATEUAT CBITER

PITTSBURGH, PA 15222-1207

ATTX, MR. JIM HBRVOI.

DATE REPORTEDE $10 / 08 / 93$

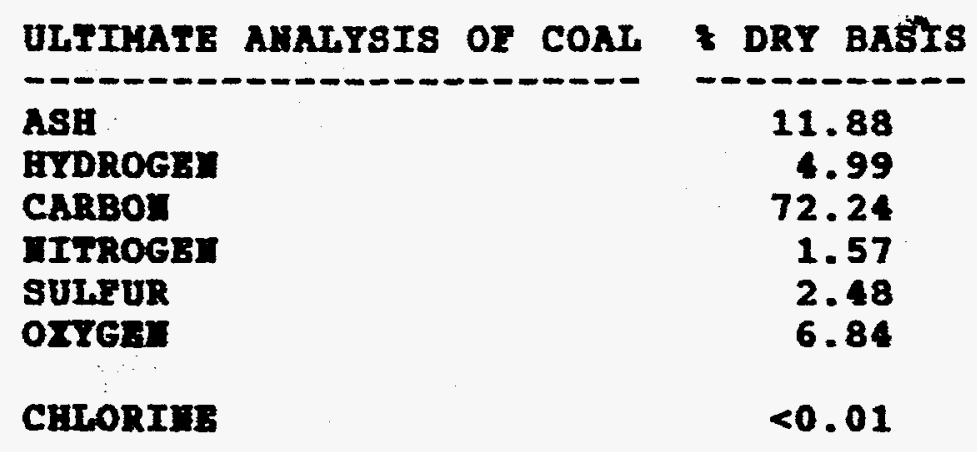

HIMBRAL AMALYSIS OF ASH \& IGITED BASIS

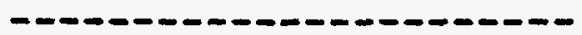

SILICON DIOZIDE (SIO2)

ALUMIIUH OXIDE (AL203).

48.10

TIFAIIUA DIOXIDE (TIO2)

25.16

CALCIUK OXIDA (CAO)

1.14

POTASSIUH OXIDE (K20)

1.70

MAGIESIUA OXIDE (KOO)

1.94

SODIUY OXIDE (MA2O)

0.78

RHOSPHORUS PAITOXIDE (P205)

0.32

FERRIC OIIDB (FB203)

SULFUR TRIOXIDE (\$O3)

0.28

UNDETERMIMED

16.62

0.96

3.00

BASE/ACID RATIO,

LBS OF ASH/HILLIOX BTU.

0.2871

SLAG VISCOSITY:

FOULIMG IXDEX,

9.18

SLAGGIXG IUDEX:

SIIICA VALUE:

+ ArXaII As MA20.
0.0919
0.7120
71.5774
0.1917


Lab. No 59019

Date Rec'd $09 / 27 / 93$

Date Sampled $09 / 22 / 93$ $1530 \%$. CULLEM AVENUE EVANSVILLE, IA 47715

Sampled By CLIEAT

ICF KAISER BNGIXEERIKG

4 GATEWAY CEHTER

PITTSBURGH, PA 15222-1207

ATTH: MR. JIM HERVOL

SAMPLE IDENTIFICATION

COAL REEDER

TEST $* 3$

GRINDABILITY MOISTURE $=2.497$

DATE REPORTED\& $\quad 10 / 08 / 93$

\begin{tabular}{|c|c|c|c|c|c|c|}
\hline & $\%$ Moisture & $\%$ Ash & $\%$ Volatile & - $\%$ Flxed Carbon & B.T.U./LB. & $\%$ Sulfur \\
\hline As Rec'd. & 12.63 & 10.41 & 33.90 & 43.06 & 11255 & 2.34 \\
\hline Dry Basis & ----- & 11.91 & 38.80 & 49.29 & 12882 & 2.68 \\
\hline M-A-Free & & & & & 14624 & \\
\hline
\end{tabular}

FREE SWELLING IHDEX : $\mathbf{X X X}$

ASH FUSION TEMPERATURES (DEG E)

INITIAL

SOFTEKING

HEYISPHGRICAL

FINAL

$\begin{array}{cc}\text { REDUCIMG } & \text { OXIDIZING } \\ 2125 & 2580 \\ 2205 & 2600 \\ 2315 & 2625 \\ 2465 & 2635\end{array}$

HARDGROVB GRINDABILITY IHDEX \& 55

NOTE: XXXX INDICATES AKALYSTS WAS YOT PEREORMED 
Lab. No

$09 / 27 / 93$

Date Rec'd

$09 / 22 / 93$

Date Sampled

CIIBUT

Sampled By

ICF KAISER BMGIMEERIMG

4 GATEWAT CBUTER

PIrTsBURGH, PA 15222-1207

ATTI, YR. JIM HERVOL
STANDARD LABORATORIES,INC.

1530 П. CULLEM AVEMUE

EVARSVIILE, In 47715

SAMPLEDATI REEDBR

TEST $\div 3$

DATE REPORTED $10 / 08 / 93$

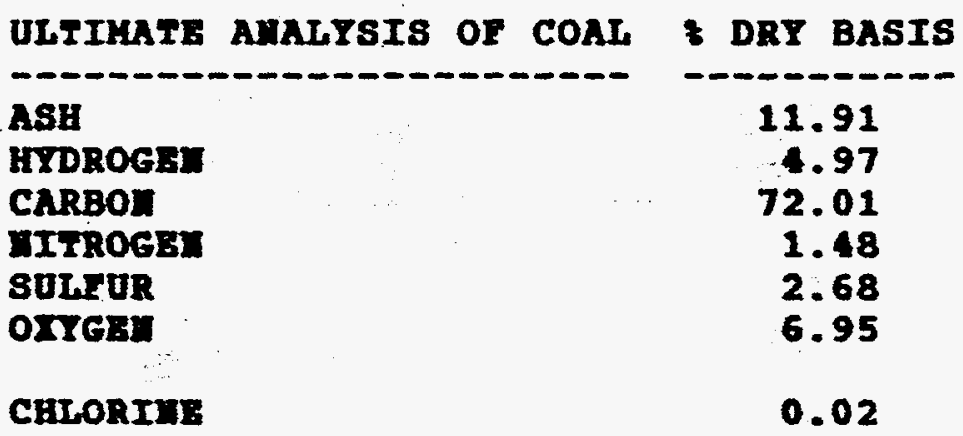

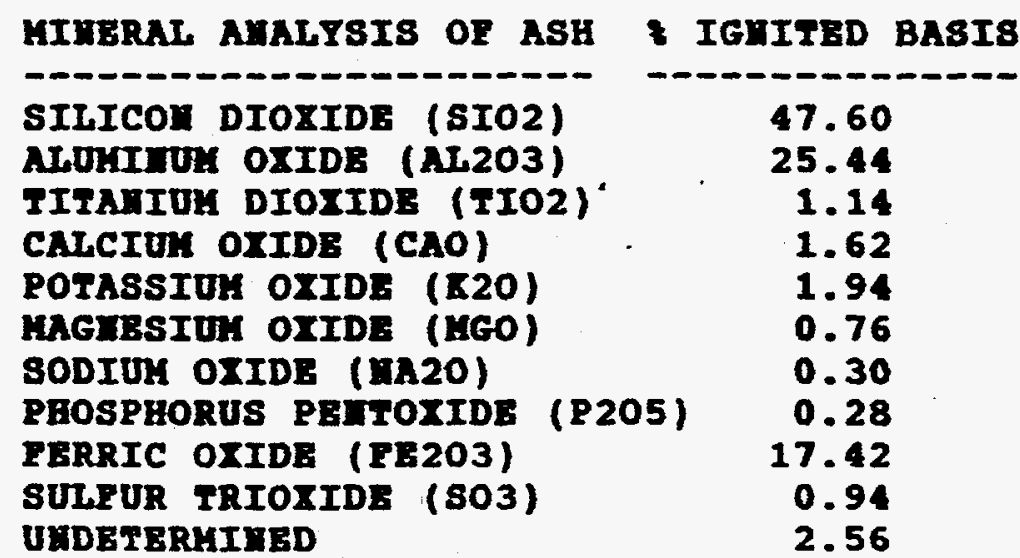

BASE/ACID RAYIO;

IBS OP ASH/AILIOIOY BTU:

SLAG VISCOSITY,

FOUIYG INDEX:

SIAGGIIG IDDEX:

SILICA VALUE:

* REKNII AS MA20.
0.2971

9.25

2550 DEG E. 250 POISE

0.0891 TYPE, LOW

70.6231
0.7962

0.1898

TYPB \& MBDIUY 
Lab. No.

Date Rec'd $09 / 27 / 93$

Date Sampled $09 / 23 / 93$ 1530 H. CULLEN AVENUE EVAKSVILLE, IA 47715

Sampled By

CLIENT

ICE KAISER EHGIMEERING

4 GATEWAY CEATER

PITTSBURGH, PA 15222-1207

ATTY, MR. JIM HERVOL

SAMPLE IDENTIFICATION

COAL FEBDER

TEST 1

GRIMDABILITY MOISTURE $=2.648$

DATE REPORTED: $10 / 08 / 93$

\begin{tabular}{lcccccc}
\hline & \% Moisture & $\%$ Ash & \% Volatile & \% Fixed Carbon & B.T.U./LB. & \% Sulfur \\
\hline As Rec'd. & 12.30 & 10.09 & 34.32 & 43.29 & 11371 & 2.46 \\
\hline Ory Basis & 12.5 & 39.13 & 49.37 & 12966 & 2.80 \\
\hline \begin{tabular}{l} 
M-A-Free \\
\hline
\end{tabular}
\end{tabular}

FREE SWELLING INDEX ; XXXX

ASH FUSION TEMPERATURES (DEG F)

INITIAL

SOFTENIXG

HEMISPHERICAL

FINAL

$\begin{array}{cc}\text { REDUCING } & \text { OXIDIZIHG } \\ 2165 & 2550 \\ 2245 & 2570 \\ 2295 & 2585 \\ 2350 & 2600\end{array}$

HARDGROVE GRINDABILITY IHDEX : 52

HOTE: XXXX IXDICATES AYALYSIS WAS YOT PERFORMED 


Lab. No. $\frac{59020}{09 / 27 / 93}$

STANDARD LABORATORIES,INC.

1530 A. CULLBI AVBUUB

EVAHSVILLE, IH 47715

SAMPLE ID

COAL FBEDER

TEST 1

ICF KAISER ERGIHEERIYG

4 GATEUAY CBITER

PITYSBURGH, PA 15222-1207

ATTI: MR. JIM HERVOT

ARSBUIC $-6.47 \mathrm{ug} / \mathrm{g}$ ASB BASIS

DATE REPORTED: $\quad 10 / 08 / 93$

\begin{tabular}{lr} 
ULTIMATE AMALYSIS OF COAL & DRY BASIS \\
\hline ASH & 11.50 \\
HYDROGEX & 4.91 \\
CARBOH & 72.32 \\
IITROGEX & 1.49 \\
BULPUR & 2.80 \\
OXTGBX & 6.98 \\
CHLORIHE & 0.03
\end{tabular}

MIHERAT ARALYSIS OF ASH

- IGIITED BASIS

SIIICON DIOXIDE (SI02)

ALUMIIUH OXIDE (RL203)

TIFAUIUH DIOXIDE (TIO2)

CALCIUH OXIDE (CAO)

POTASSIUY OIIDE (X20)

MAGIBSIUM OXIDE (KGO)

SODIUH OXIDE (WA20)

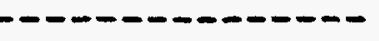

PHOSPHORUS PEHTOXIDE (P205)

45.20

FERRIC OXIDE (FE203)

SULPUR TRIOIIDB (SO3)

24.30

1.04

2.04

1.74

0.70

0.28

0.30

20.30

1.13

UMDETERHIKBD

2.97

BASE/ACID RATIO:

0.3553

LBS OF ASH/MILLIOH BRU,

8.87

SIAAG VISCOSITY:

FOULIXG INDEX,

SLAGGIXG IXDEX,

SILICA VALUE,

* MIKAII AS MA2O:

2460

0.0995

0.9948

66.2368

0.1657

F. 7250 POISE

TYPE : LON

TYPE: MBDIUK 
Lab. No.

59021

Date Rec'd

$09 / 27 / 93$

Date Sampled $09 / 23 / 93$

Sampled By

CLIEII

ICF KAISER EMGINEERIYG

4 GATEWAY CEMTER

PITTSBURGH, PA 15222-1207.

ATTY, MR. JIM HERVOL

1530 H. CULLEY AVENUE

EVARSVILLE, IH 47715

SAMPLE IDENTIFICATION

COAL FEEDER

TEST $\$ 2$

GRIXDABILITY MOISTURE $=2.57$ \%

DATE REPORTED\& $10 / 08 / 93$

\begin{tabular}{lcccccc}
\hline \hline & $\%$ Moisture & $\%$ Ash & \% Volatile & \% Fixed Carbon & B.T.U./LB. & \% Sulfur \\
\hline As Rec'd. & 13.36 & 9.48 & 34.09 & 43.07 & 11335 & 2.37 \\
\hline Dry Basis & $-1 .-$ & 10.94 & 39.35 & 49.71 & 13083 & 2.74 \\
\hline M-A-Free & & & & & 14690 & \\
\hline \hline
\end{tabular}

FREE SWELLING IYDEX , XXXX

$\begin{array}{lcc}\text { ASH FUSION TEMPERATURES (DEG F) } & \text { REDUCIYG } & \text { OXIDIZIYG } \\ \text { IHITIAL } & 2170 & 2560 \\ \text { SOFTEMIYG } & 2250 & 2575 \\ \text { HEHISPHERICAL } & 2345 & 2585 \\ \text { EIKAL } & 2410 & 2600\end{array}$

HARDGROVE GRINDABILITY IHDEX \& 54

NOTE, XXXX IXDICATES AMALYSIS WAS NOT PERFORMED FOR YOUR PROTECTION THIS DOCUMENT HAS BEEN PRINTED ON CONTROUED PAPER STOCK.

Respectfully Submitted, NOT VALD IF ALTERED.

BRETT A. STOCK 
Lab. No.

$09 / 27 / 93$

Date Rec'd

$09 / 23 / 93$

Date Sampled CLIBXY

Sampled By

ICF KATSER EMGIUEERIMG

- Gatbuat cBHTER

PITTSBURGH, PA 15222-1207

ATTY, MR. JIH HERVOL

\section{$\Omega$}

STANDARD LABORATORIES,INC.

1530 サ. CULLBX AVERUE

EVAXSVILLE, IX 47715

SAMPLECBAL FEBDER

TEST 2

DATE REPORTED \& $10 / 08 / 93$

ULTIMATE AKALYSIS OF COAL F DR BASIS

$\begin{array}{lr}\text { ASH } & 10.94 \\ \text { IYDROGEI } & 4.96 \\ \text { CARBOI } & 72.86 \\ \text { IITROGEI } & 1.56 \\ \text { SULFUR } & 2.74 \\ \text { OXYGRI } & 6.94 \\ \text { CHLORIUE } & 0.02\end{array}$

MIMERAL AMATSIS OF ASH

* IGITERD BASIS

SILICOI DIOXIDE (SIO2)

ALUMInUH OXIDE (AT.203)

IIFAIIUH DIOXIDE (TIO2)

CALCIUH OXIDE (CAO)

POTASSIUK OXIDE (K20)

MAGIESIUH OXIDE (HGO)

SODIUA OZIDE (MA2O)

PHOSPHORUS REHTOXIDE (P205)

$-0---0-0--$

FERRIC OXIDE (FE203)

SULEUR TRIOXIDE (S03)

45.10
24.60

1.10

2.04

1.74

0.78

0.30

0.28

UUDETERMIMED

19.94

1.13

2.99

BASE/ACID RATIO,

0.3503

LBS OF ASH/MILIIOA BTU:

8.36

SLAG VISCOSITY:

YOULIXG IHDEX:

2470

F. 250 POISE

SLAGGIMG IMDEX:

0.1051

0.9598

TYPE, LOW

SIXICA VALUE,

66.4604

\& ALKAII As un20,

0.1598

TYPE: MBDIUH

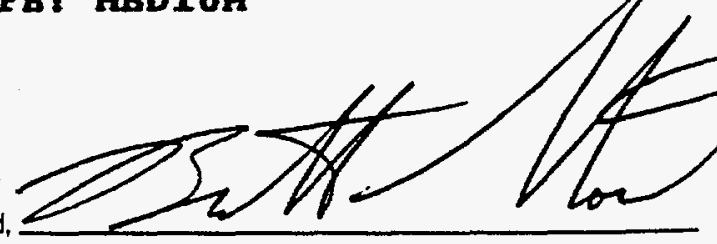

BRETT A. STOCK 
Lab. No.

Date Rec'd

$09 / 27 / 93$

Date Sampled $09 / 23 / 93$

1530 A. CULLEY AVEXUE

EVANSVILLE, IH 47715

Sampled By

CLIPUT

ICF KAISER BHGINERRIHG

4 GATEHAY CBHTER

PITTSBURGH, PA 15222-1207

ATTX: MR. JIH HERVOL

SAMPLE IDENTIFICATION

COAL FEEDER

TEST 3

GRIHDABILITY MOISTURE $=2.728$

DATE REPORTED, $10 / 08 / 93$

\begin{tabular}{|c|c|c|c|c|c|c|}
\hline & $\%$ Moisture & $\%$ Ash & $\%$ Volatile & \% Fixed Carbon & B.T.U./LB. & $\%$ Sulfur \\
\hline As Rec'd. & 13.32 & 10.31 & 33.76 & . 42.61 & 11189 & 1.86 \\
\hline Dry Basis & $-\infty-\infty$ & 11.90 & 38.95 & 49.15 & 12908 & 2.15 \\
\hline M-A-Free & & & & & 14652 & \\
\hline
\end{tabular}

FREE SWELLING IHDEX : XXXX

$\begin{array}{lccc}\text { ASH FUSION TEMPERATURES } & \text { (DEG F) } & \text { REDUCIXG } & \text { OXIDIZING } \\ \text { IHITIAL } & 2205 & 2595 \\ \text { SOFTEYIHG } & 2300 & 2620 \\ \text { HEMISPHERICAL } & 2405 & 2635 \\ \text { FIMAL } & & 2505 & 2650\end{array}$

HARDGROVE GRIHDABILTTY INDEX , 54

HOTE: XXXX INDICATES ANALYSIS WAS NOT PERFORMED 


\begin{tabular}{|c|c|}
\hline Lab. No. & 59022 \\
\hline te $R e c^{\prime}$ & $09 / 27 / 93$ \\
\hline & $09 / 23 / 93$ \\
\hline & CLIBXT \\
\hline
\end{tabular}

STANDARD LABORATORIES,INC.

\author{
1530 \#. CULLEX AVEHUE \\ BVAMSVILLE, IX 47715
}
SAMPLEISAT FEEDER
TEST $\div 3$

ICF KAISER EMGIHEERIMG

4 GATEMAT CENTER

PITTSBURGH, PA 15222-1207

ATTI: HR. JIM HBRVOL

DATE RBPORTBD: $10 / 08 / 93$

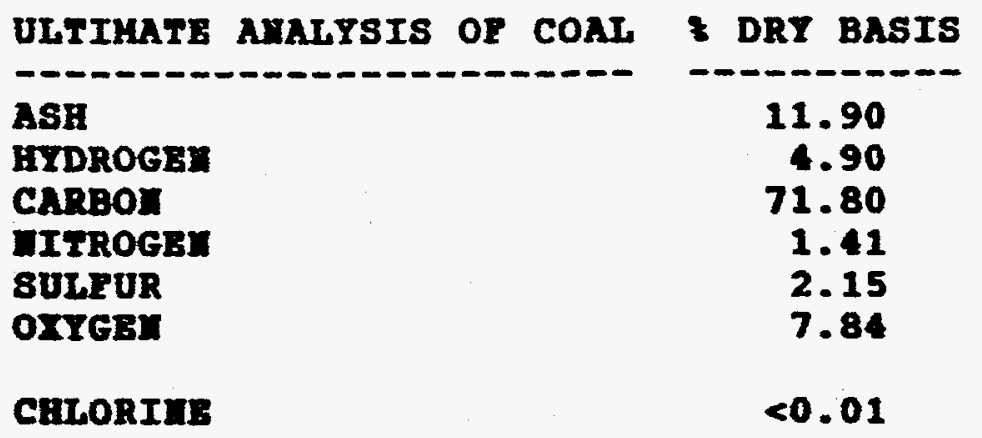

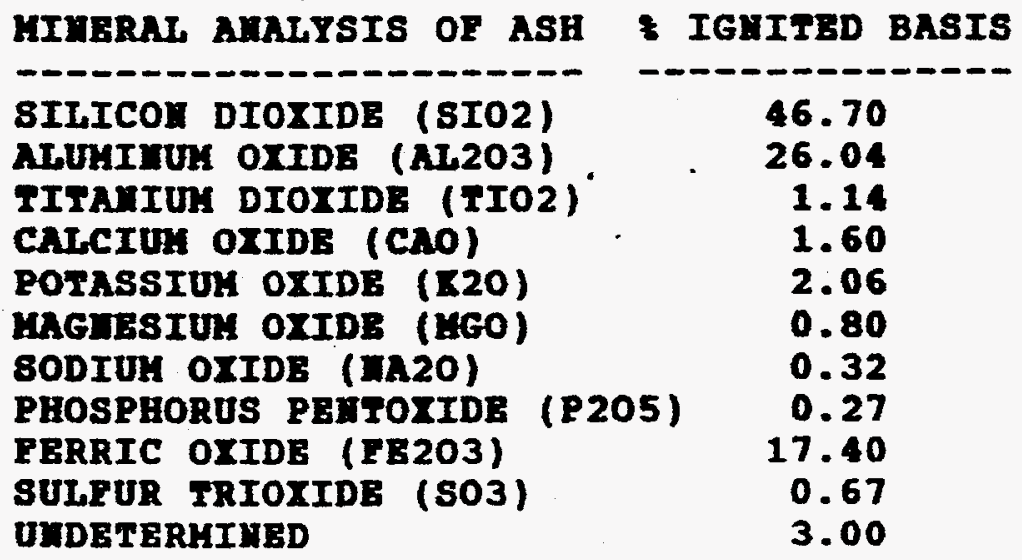

BASE/ACID RATIO:

LBS OF ASH/MILLION BTU , 9.22

SIAG VISCOSITY:

FOULIHG IUDEX:

SLAGGIVG IUDBX,

SILICA VALUE,

2550 DEG F. 2250 POISE

? ALRALI AS MA20, 0.2016

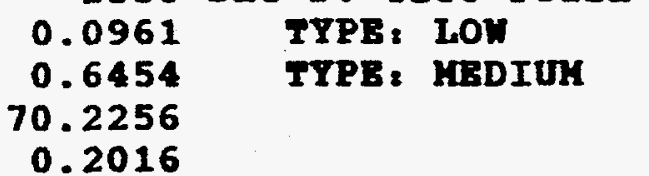

Respectfully Submitted,

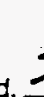

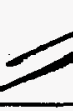


Lab. No

59023

Date Rec'd $09 / 27 / 93$

Date Sampled

$09 / 23 / 93$

Sampled By

\section{CLIBHT}

ICF KAISER EHGIHEERING

4 GATEWAY CENTER

PITTSBURGH, PA 15222-1207

ATTY, MR. JIY HERVOL

SAMPLE IDENTIFICATION

COAL FEEDER

PH 10

GRINDABILITY MOISTURE $=2.728$

DATE REPORTED: $\quad 10 / 08 / 93$

\begin{tabular}{lccccccc}
\hline & $\%$ Moisture & \% Ash & $\%$ Volatile & \% Fixed Carbon & B.T.U./LB. & $\%$ Sulfur \\
\hline As Rec'd. & 13.98 & 10.02 & 33.30 & .42 .70 & 11104 & 2.12 \\
\hline Dry Basis & - & 11.65 & 38.71 & 49.64 & 12909 & 2.47 \\
\hline
\end{tabular}

M-A-Free

14611

FREE SWELLIYG IMDEX \& XXXX

ASH FUSION TEMPERATURES (DEG F)

REDUCING

2295

2400

2485

2570
1530 N. CULLEN AVENUE

gVANSVILLE，IN 47715
INITIAL

SOFTEKIMG

HEMISPHERICAL

EINAL

HARDGROVE GRINDABILITY IMDEX : 53

NOTE: XXXX INDICATES ANALYSIS WA
HOT PERFORMED

Respectfully Submitted,

BRETT A. STOCK 
59023

Date Rec'd $\frac{09 / 27 / 93}{09 / 23 / 93}$

STANDARD LABORATORIES,INC.

\section{0 \%. CULLEH AVEMUE \\ EVAUSVILLE, II 47715}

SAMPLE CBAL REEDER

PM 10

ICF KAISBR BMGIMEERIMG

4 GATBWAY CEDTBR

PITTSBURGH , PA 15222-1207

ATTI, MR. JIH HBRVOL

DATE REPORTED = $10 / 08 / 93$

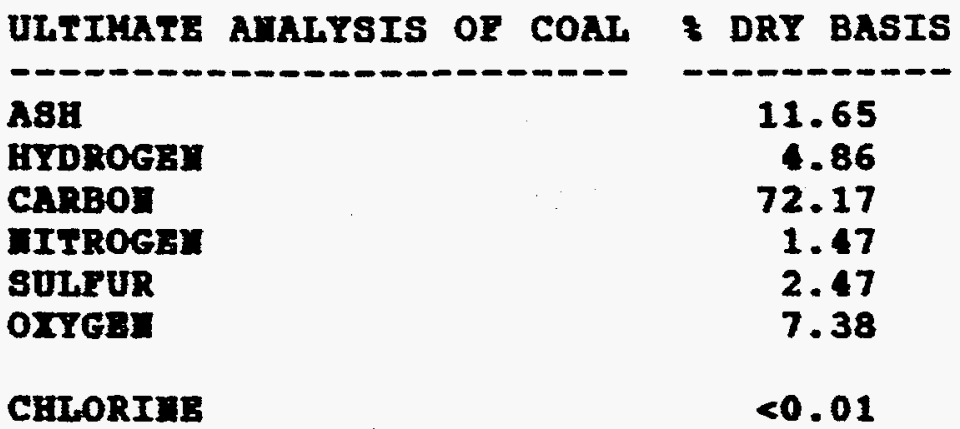

MIHERAL AMALSIS OF ASH

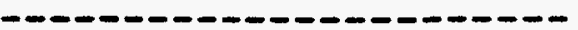

I IGYITBD BASIS

SILICON DIOXIDE (SI02)

47.90

ALUATrun OXIDE (AL203)

26.20

TIFAIIUA DIOXIDE (TIO2)

1.12

CARCIUA OXIDE (CAO)

1.72

POTASSIUH OXIDE (K20)

2.08

MAGTESIUH OXIDE (HGO)

0.86

SODIUH OXIDE (MA2O)

PHOSRHORUS PEHTOXIDE (P205)

0.32

FERRIC OXIDE (FE203)

0.31

SULEUR TRIOXIDE (SO3)

15.54

0.95

UMDETERMIYED

3.00

BASE/ACID RATIO:

0.2728

LBS OF ASH/MILLION BTU,

9.02

SLAG VISCOSITY:

2600

FOULIYG IHDEX,

0.0873

DEG F. T250 POISE

SLAGGIBG IMDEX:

0.6738

TYPE, LON

SILICA VALUE,

72.5538

$t$ MLKALI AS HA20.

0.1989

TYPE, MBDIUH 
Lab. No. 59024

Date Rec'd $09 / 27 / 93$

Date Sampled $09 / 24 / 93$

Sampled By CIIPIT

ICE KAISER BHGIHEERING

4 GATENAY CENTER

PITTSBURGH, PA 15222-1207

ATTY, MR. JIM HERVOL

\section{$1530 \%$. CULLEN AVENUE}

EVANSVILLE, IN 47715

SAMPLE IDENTIFICATION

COAL FEEDER

TBST $\$ 1$

GRINDABILITY MOISTURE $=2.98 t$

DATE REPORTED: $10 / 08 / 93$

\begin{tabular}{lcccccc}
\hline & \% Moisture & \% Ast & \% Volatie & \% Fixed Carbon & B.T.U./LB & \% Sulfur \\
\hline As Rec'd. & 13.29 & 9.44 & 34.66 & 42.61 & 11314 & 2.32 \\
\hline Dry Basis & & 10.89 & 39.97 & 49.14 & 13048 & 2.68 \\
\hline M-A-Free & & & & & & \\
\hline
\end{tabular}

FREE SWELLING INDEX : XXXX

ASH FUSION TEMPERATURES (DEG F)

INITIAL

SOFTEXIKG

HEMISPHERICAL

EIHAL

$\begin{array}{cc}\text { REDUCIMG } & \text { OXIDIZIMG } \\ 2220 & 2615 \\ 2370 & 2625 \\ 2420 & 2640 \\ 2495 & 2655\end{array}$

HARDGROVE GRINDABILITY INDEX : 50 


\begin{tabular}{ll} 
Lab. No. $\frac{59024}{09 / 27 / 93}$ \\
Date Rec'd $\frac{09 / 24 / 93}{09 / 24} \frac{\text { CLIBNT }}{\text { Date Sampled }}$ \\
\hline Sampled By $\quad$ CIBS
\end{tabular}

SAMPLE ID:

CONL FBEDER
TBST $\$ 1$

ICF KAISER BRGIMEERIMG

4 GATEWAY CEITER

PITTSBURGH, PA 15222-1207

ATTI: YR. JIM HERVOL

ARSEHIC $=9.61 \mathrm{ug} / \mathrm{g}$ ASH BASIS

DATE REPORTED: $10 / 08 / 93$

1530 A. CULLES AVBUUE
EVALSVILLE, IR 47715 
Lab. No.

Date Rec'd

$09 / 27 / 93$

Date Sampled

$09 / 24 / 93$

Sampled By

CLIBIT

ICF KAISBR BAGINEERIYG

4 GATEWAY CEMTER

PITTSBURGH, PA 15222-1207.

AIIA: MR. JIM HERYOL

1530 H. CULLEN AVENUE

EVAKSVILLE, IN 47715

SAMPLE IDENTIFICATION

COAL FEEDER

TEST $\$ 2$

GRIMDABILITY MOISTURE $=2.768$

DATE REPORTED: $10 / 08 / 93$

\begin{tabular}{|c|c|c|c|c|c|c|}
\hline & $\%$ Moisture & $\%$ Ash & $\%$ Volatile & $\%$ Fixed Carbon & B.T.U./LB. & \% Sulfur \\
\hline As Rec'd. & 13.21 & 10.12 & 34.16 & 42.51 & 11213 & 2.16 \\
\hline Dry Basis & ---- & 11.66 & 39.36 & 48.98 & 12920 & 2.49 \\
\hline M-A-Free & & & & & 14625 & \\
\hline
\end{tabular}

FREE SWELLING IRDEX , XXXX

\begin{tabular}{|c|c|c|}
\hline $\begin{array}{l}\text { ASH FUSIOH TEMPERATURES IDEG F } \\
\text { INITIAL } \\
\text { SOFTENING } \\
\text { HEMISPHERICAL } \\
\text { FIRAI }\end{array}$ & $\begin{array}{c}\text { REDUCIKG } \\
2230 \\
2375 \\
2430 \\
2490\end{array}$ & $\begin{array}{l}\text { OXIDIZING } \\
2645 \\
2660 \\
2675 \\
2690\end{array}$ \\
\hline
\end{tabular}

HARDGROVE GRINDABILITY INDEX : 51

NOTE: XXXX INDTCATES ANALYSIS WAS NOT PERFORMED 
Lab. No.

$09 / 27 / 93$

Date Rec'o

$09 / 24 / 93$

Date Sampled CLIBUT

Sampled By

ICF KATSER BMGIUEERIMG

L GATBUAT CEMTER

PITTSBURGH, PA 15222-1207

ATTI: HR. JIH HERVOL
STANDARD LABORATORIES,INC.

1530 M. CULLE⿰丿 AVBHUB

EVARSVILLE, II 47715

\section{SAMPLECBAL FBEDER}

TBST $\$ 2$

DATE REPORTED; $\quad 10 / 08 / 93$

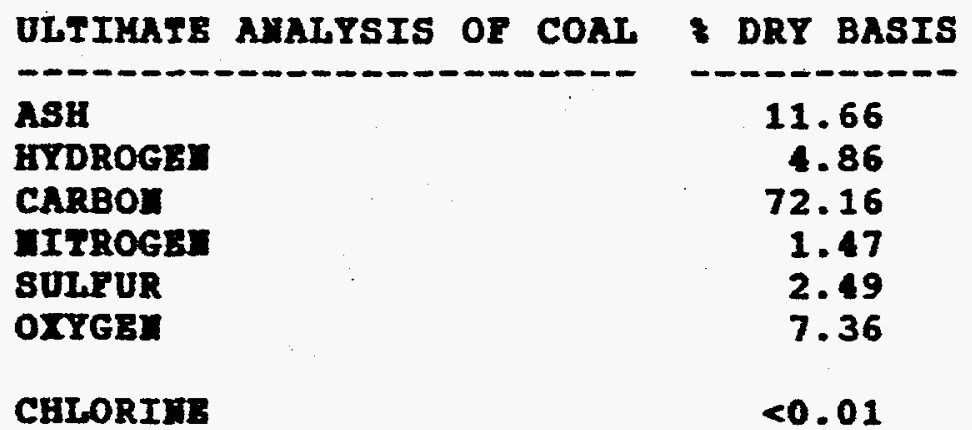

MIMERAL AMALYSIS OF ASH

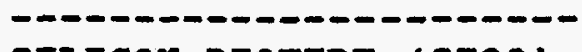

SILICOA DIOXIDE (SI02)

\& IGITTED BASIS

AIUMIMUH OXIDE (AL203)

TITAHIOA DIOXIDE (TIO2)

CALCIUA OXIDE (CNO)

POTASSIUH OXIDE (K20)

MAGESIUH OXIDE (HGO)

SODIUY OXIDE (MA20)

PHOSPBORUS PBHTOXIDE (P205)

FERRIC OIIDE (EE203)

SULFUR TRIOXIDE (S03)

UYDETERYIYED

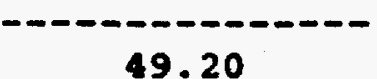

49.20

26.38

1.10

1.70

2.04

0.80

0.32

0.29

14.34

0.87

2.96

BASE/ACID RATIO:

IBS OP ASH/HILLIOH SIAG VISCOSTTY,

BTU:

FOULIKG IHDEX,

SIARGIIG IMDEX:

SILICA VALUB,

z ALKaLI AS MA2Os

0.2504

9.02

2630 DEG $F$. T250 POISE

0.0801 TYPE: LOH

0.6235 TYPE, HEDIUH

74.5003

0.1960 
Lab. No.

Date Recid

$09 / 27 / 93$

Date Sampled $09 / 24 / 93$

1530 N. CULLEN AVENUE

EVANSVILLE, IN 47715

Sampled By

CLIENT

ICE KAISER ENGINEBRING

4 GATENAY CEHTER

PITTSBURGH, PA 15222-1207

ATTH, HR. JIH HERVOL

SAMPLE IDENTIFICATION

COAL FEEDER

TEST $\div 3$

GRIMDABILITY HOISTURE $=2.78 \%$

DATE REPORTED: $\quad 10 / 08 / 93$

\begin{tabular}{|c|c|c|c|c|c|c|}
\hline & $\%$ Moisture & $\%$ Ash & $\%$ Volatile & $\%$ Fixed Carbon & B.T.U./LB. & $\%$ Sulfur \\
\hline As Rec'd. & 13.09 & 9.62 & 33.73 & 43.56 & 11373 & 2.09 \\
\hline Dry Basis & ---- & 11.07 & 38.81 & 50.12 & 13086 & 2.41 \\
\hline M-A-Free & & & & & 14715 & \\
\hline
\end{tabular}

FREE SWELLING INDEX : XXXX

ASH FUSION TEHPERATURES (DEG F)

IHITIAL.

SOFTEKIKG

HEMISPHERICAL

FINAL

$\begin{array}{cc}\text { REDUCIMG } & \text { OXIDIZIMG } \\ 2225 & 2590 \\ 2355 & 2625 \\ 2410 & 2645 \\ 2505 & 2675\end{array}$

HARDGROVE GRINDABILITY IKDEX : 51

NOTE: XXXX INDICATES ANALYSIS WAS NOT PERFORMED

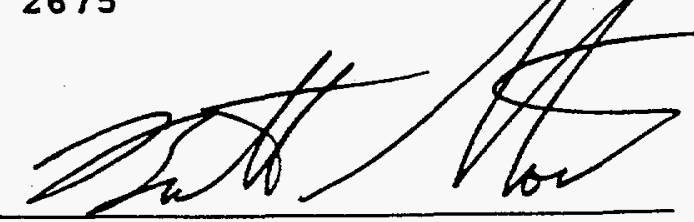
NOT VALID IF ALTERED. 


Lab. No. $\frac{59026}{09 / 27 / 93}$
Date Rec'd $\frac{09}{09 / 24 / 93}$
Date Sampled $\frac{09}{\text { CLIEIYT }}$
Sampled By

SAMPLE ID:

ICF RAISER BMGIMBERIMG

4 GATEWAY CEITER

PITTSBURGH, PA 15222-1207

ATTI, MR. JIM HERVOL

COAL REEDBR

TEST $* 3$

$1530 \%$. CULLEH AVEMUB

EVAMSVILLE, IA 47715

DATE REPORTED: $10 / 08 / 93$

\begin{tabular}{lr} 
ULTIMATE AMALYSIS OF COAL & DRY BASIS \\
\hline ASH & 11.07 \\
HYDROGEX & 4.97 \\
CARBOH & 73.03 \\
UITROGBH & 1.57 \\
SULFUR & 2.41 \\
OIYGRI & 6.95 \\
CHLORIME & 0.02
\end{tabular}

HIMERAL AHALYSIS OP ASH * IGUITED BASTS

SIIICON DIOIIDE (SIO2)

ALUKIITH OXIDE (AT.203)

49.00

ALUTIUS OXIDE (AL203)

25.98

CALCIUH OXIDE (CAO)

1.18

1.96

POTASSIUH OIIDE (K20)

2.02

0.84

HAGIBSIUH OXIDE (HGO)

SODIUK OXIDE (EA20)

PHOSPHORUS PBITOXIDE (P205)

0.30

FERRIC OXIDE (FE203)

SULFUR TRIOXIDE (SO3)

0.26

UNDETERMINED

15.04

1.11

2.31

BASE/ACID RATIO:

LBS OF ASH/HILLIOR BTU

SIAG VISCOSITY:

0.2647

FOULIYG IHDEX,

SLAGGIUG IMDEY:

SIIICA VALUB:

I ALXALI AS MA20:

2620

8.46

0.0794

0.6379

DEG $F$. T250 POISE

TYPE \& LON

73.3094

TYPE: MBDIUY

0.1824

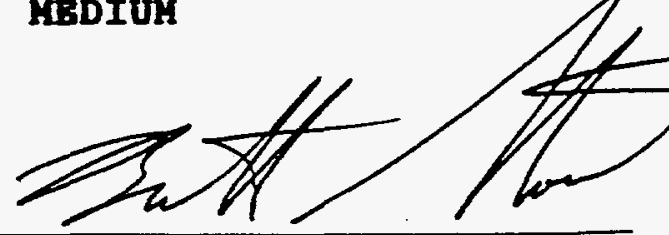


Lab. No. 59027

Date Rec'd

$09 / 27 / 93$

Date Sampled

$09 / 24 / 93$

Sampled By

CLIENT

ICF KAISER BNGINEERIYG

4 GATEWAY CEXTER

PITTSBURGH, PA 15222-1207

ATTY, KR. JIM HERVOL

\section{A. CULLEH AVENUE}

EVANSVILLE, IA 47715

SAMPLE IDENTIFICATION

COAL FEEDER

PM 10

GRINDABILITY MOISTURE $=2.898$

DATE REPORTED, $10 / 08 / 93$

\begin{tabular}{|c|c|c|c|c|c|c|}
\hline & $\%$ Moisture & $\%$ Ash & $\%$ Volatile & $\%$ Fixed Carbon & B.TU./LB & $\%$ Sulfur \\
\hline As Rec'd. & 13.71 & 10.24 & 33.31 & 42.74 & 11112 & 2.13 \\
\hline Dry Basis & ----- & 11.87 & 38.60 & 49.53 & 12877 & 2.47 \\
\hline M-A-Free & & & & & 14611 & \\
\hline
\end{tabular}

FREE SWELLING IHDEX : XXXX

$\begin{array}{lccc}\text { ASH FUSION TEMPERATURES } & \text { (DEG F) } & \text { REDUCING } & \text { OXIDIZING } \\ \text { IXITIAL } & & 2230 & 2610 \\ \text { SOFTENING } & & 2360 & 2640 \\ \text { HEMISEHERICAL } & 2415 & 2660 \\ \text { FINAL } & & 2500 & 2695\end{array}$

HARDGROVE GRINDABILITY INDEX : 53

NOTE: XXXX INDICATES ANALYSIS WAS HOT PERFORMED 
Lab. No.

59027

Date Rec'd

$09 / 27 / 93$

Date Sampled

$09 / 24 / 93$

Sampled By

$$
\text { CLTEX2 }
$$

ICF KAISER ENGIMEBRIYG

- GATBHAT centBR

PITTSBURGH, PA 15222-1207

ATTU: MR. JIM HBRVOL
STANDARD LABORATORIES,INC.

1530 M. CULLEI AVETUE

EVAASVILLE， IX 47715

SAMPLEID

COAL REBDER

PH 10

DATE REPORTED: $10 / 08 / 93$

\begin{tabular}{lc} 
ULTIMATE AMALYSIS OF COAL & DRY BASIS \\
\hline ASH & 11.87 \\
HYDROGEI & 4.95 \\
CARBOI & 72.00 \\
MITROGEI & 1.56 \\
SULFUR & 2.47 \\
OIYGEI & 7.15 \\
CALORIXE & 0.03
\end{tabular}

MIIERAL AMAYSIS OF ASH I IGITED BASIS

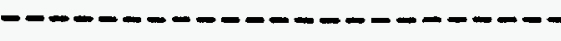

SILICON DIOXIDE (SI02)

ALUKIMUM OXIDE (AL203)

TITAMIOH DIOXIDE (TIO2)

CALCIUM OXIDE (CAO)

POTASSIUM OXIDE (K20)

MAGTESIUY OXIDE (MGO)

SODIUH OXIDE (MA2O)

PHOSPHORUS PEETOIIDE (P205)

FERRIC OXIDE (FB203)

SULFUR TRIOIIDE (SO3)

UHDETERMIMED

BASE/ACID RATIO:

LBS OF ASH/MILLIOH BTU,

SLAG VISCOSITY:

FOULIKG IHDEX:

SIAGGIHG IHDEX,

SIIICA VALUB:

* MLRALI AS HA20,

73.6086

0.2058
49.20

25.60

1.16

1.70

2.12

0.84

0.32

0.28

15.10

0.93

2.75

\subsection{3}

9.22

2620 DEG F. T250 POISE

0.0846 TYPE: LOH

0.6528 TTPE: MBDIUH

Respectfully Submitted,

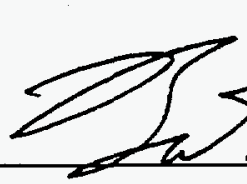

BRETT A. STOCK 
Lab. No

62226

Date Rec'o

$12 / 08 / 93$

Date Sampled

$12 / 07 / 93$

1530 N. CULLEN AVENUE

EVANSVILLE, IN 47715

Sampled By

CLIENT

ICF KAISER ENGINEERING

4 GATEWAY CENTER

PITTSBURGH, PA 15222-1207

ATTN: MR. JIM HERVOL

SAMPLE IDENTIFICATION

STACK TEST

\#1

LIFAC DEMONSTRATION

DATE REPORTED: $12 / 16 / 93$

\begin{tabular}{|c|c|c|c|c|c|c|}
\hline & $\%$ Moisture & $\%$ Ash & $\%$ Volatile & $\%$ Fixed Carbon & B.T.U./LB. & $\%$ Sulfur \\
\hline As Rec'd. & 12.65 & 9.73 & 32.96 & 44.66 & 11356 & 2.32 \\
\hline Dry Basis & ---- & 11.14 & 37.73 & 51.13 & 13001 & 2.66 \\
\hline M-A-Free & & & & & 14631 & \\
\hline
\end{tabular}

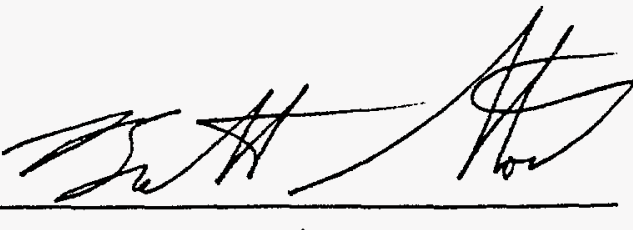


Lab. No.

62226

$12 / 08 / 93$

Date Rec'd

$12 / 07 / 93$

Date Sampled

CLIFIT

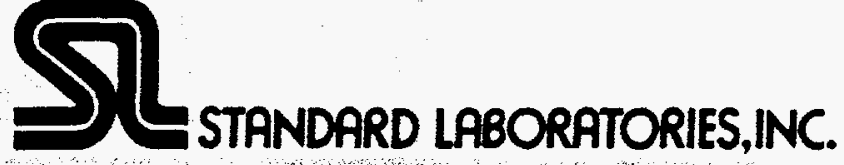

1530 M. CULLEY AVBUUE

BVAUSVILLE, IN 47715

Sampled By

SAMPLE ID:

ICF KAISER ENGINEERIYG

4 GATEWAY CENTER

PITTSBURGH, PA 15222-1207

ATTN.: MR. JIM HERVOL
STACK TEST

$\$ 1$

IIFAC DEMOKSTRATIOY

DATE REPORTED : $12 / 16 / 93$

\begin{tabular}{lc} 
ULTIMATE ANALYSIS OF COAL & DRY BASIS \\
\hline ASH & 11.14 \\
HYDROGEN & 4.80 \\
CARBOH & 73.32 \\
HITROGEN & 1.59 \\
SUIFUR & 2.66 \\
OXYGEY & 6.49
\end{tabular}

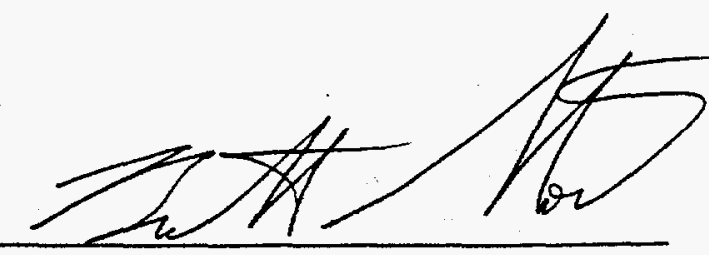


Lab. No 62227

Date Rec'd $12 / 08 / 93$

Date Sampled $12 / 07 / 93$

Sampled By

$$
\text { CLIENT }
$$

ICE KAISER ENGINEERING

4 GATEWAY CENTER

PITTSBURGH, PA 15222-1207

ATTN: MR. JIM HERVOL

SAMPLE IDENTIFICATION

STACK TEST

\#2

LIFAC DEMONSTRATION

DATE REPORTED: $\quad 12 / 16 / 93$

\section{N. CULLEN AVENUE \\ EVANSVILLE, IN 47715}




Lab. No. $\frac{62227}{12 / 08 / 93}$
Date Rec'd. $\frac{12 / 07 / 93}{\text { Date Sampled } \frac{12}{\text { CLIEXT }}}$
Sampled By

$1530 \mathrm{H}$. CULIEY AVENUE EVARSVIIIE, IA 47715

SAMPLE ID:

ICE RAISER BMGINEERIYG

4 GATENAY CENTER

PITTSBURGH, PA 15222-1207

ATTK.: MR. JIM HERVOL
STACX TEST

$\because 2$

LIFAC DEMOHSTRATION

DAFE REPORTED: $12 / 16 / 93$

\begin{tabular}{lr} 
ULTIMATE ANALYSIS OF COAL & DRY BASIS \\
\hline ASH & 11.29 \\
HYDROGEX & 4.88 \\
CARBOH & 72.87 \\
MITROGEN & 1.49 \\
SULEUR & 2.56 \\
OXYGEN & 6.91
\end{tabular}


Lab. No. 62228

Date Rec'd $12 / 08 / 93$

Date Sampled $12 / 07 / 93$

Sampled By

CLIENT

ICF KAISER ENGINEERING

4 GATEWAY CENTER

PITTSBURGH, PA 15222-1207

ATTN: MR. JIM HERVOL

SAMPLE IDENTIFICATION

STACK TEST

\#3.

LIFAC DEMONSTRATION

DATE REPORTED: $12 / 16 / 93$

\begin{tabular}{|c|c|c|c|c|c|c|}
\hline & $\%$ Moisture & $\%$ Ash & $\%$ Volatile & $\%$ Fixed Carbon & B.T.U./LB. & $\%$ Sulfur \\
\hline As Rec'd. & 12.62 & 10.01 & 33.63 & 43.74 & 11334 & 2.33 \\
\hline Dry Basis & ----- & 11.45 & 38.49 & 50.06 & 12971 & 2.67 \\
\hline M-A-Free & & & & & 14648 & \\
\hline
\end{tabular}

1530 N. CULLEN AVENUE EVANSVILLE, IN 47715 
Lab. No.

Date Rec'd

$12 / 08 / 93$

Date Sampled $12 / 07 / 93$

1530 X. CULIEX AVENUE EVAHSVILLE, IN $\mathbf{4 7 7 1 5}$

Sampled By

CLIEXT

SAMPLE ID:

ICF KAISBR ENGINBERING

4 GATEWAY CEYTER

PITTSBURGH, PA 15222-1207

ATTY.: MR. JIM HERVOL
STACK TBST

$\because 3$

LIFAC DEMONSTRATIOA

DATE REPORTED:

\begin{tabular}{lc} 
ULTIMATE AMALYSIS OF COAL & DRY BASIS \\
\hline ASH & 11.45 \\
HYDROGEY & 4.85 \\
CARBON & 73.31 \\
NITROGEY & 1.44 \\
SULEUR & 2.67 \\
OXYGEX & 6.28
\end{tabular}

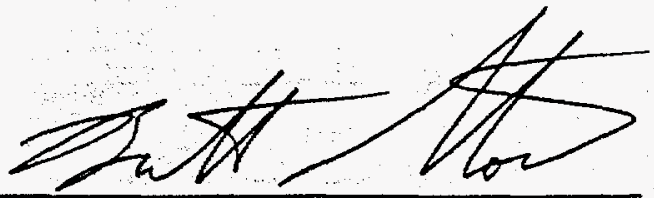


Lab. No. 62229

Date Rec'd $12 / 08 / 93$

Date Sampled $12 / 07 / 93$

$1530 \%$. CULLEN AVENUE EVANSVILLE, IN 47715

Sampled By

\section{CLIENT}

ICF KAISER ENGINEERING

4 GATEHAY CENTER

PITTSBURGH . PA 15222-1207

ATTN: MR. JIM HERVOL

SAMPLE IDENTIFICATION

STACK TEST

\#4

IIEAC DEMONSTRATION

DATE REPORTED: $\quad 12 / 16 / 93$

\begin{tabular}{|c|c|c|c|c|c|c|}
\hline & $\%$ Moisture & $\%$ Ash & $\%$ Volatile & $\%$ Fixed Carbon & B.T.U./LB. & $\%$ Sulfur \\
\hline As Rec'd. & 12.18 & 9.55 & 33.21 & 45.06 & 11505 & 2.06 \\
\hline Dry Basis & ----- & 10.87 & 37.82 & 51.31 & 13101 & 2.35 \\
\hline M-A-Free & & & & & 14699 & \\
\hline
\end{tabular}


Lab. No

62229

Date Rec'd $12 / 08 / 93$

Date Sampled $12 / 07 / 93$

Sampled By CIIBVI
1530 H. CULIER AVENUE EVAUSVTLLE， IX 47715

47715

SAMPLE ID:

ICF KAISER BNGINEERING

4 GATEHAY CENTER

PITTSBURGH, PA 15222-1207

ATTY.: HR. JIY HERVOL
STACK TEST

$\$ 4$

LIFAC DEMONSTRATIOH

DATE REPORTED : $12 / 16 / 93$

\begin{tabular}{lr} 
ULTIMATE ANALYSIS OF COAL & DRY BASIS \\
\hline ASH & 10.87 \\
HYDROGEN & 4.82 \\
CARBON & 73.62 \\
HITROGEN & 1.43 \\
SULFUR & 2.35 \\
OXYGEY & 6.91
\end{tabular}

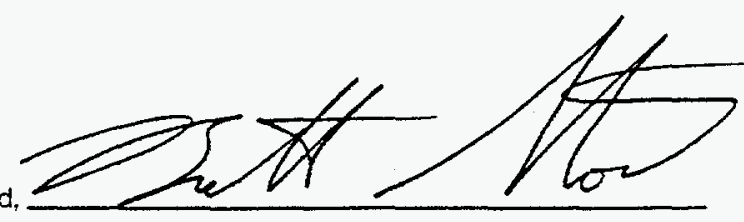


-

Lab. No.

62322

Date Rec'd

$12 / 08 / 93$

Date Sampled $12 / 07 / 93$

Sampled By

CLIENT

ICF KAISER ENGINESRING

4 GATEWAY CENTER

PITTSBURGH, PA 15222-1207

ATTN: MR. JIM HERVOL

$1530 \mathrm{~N}$. CULLEN AVENUE

EVANSVILLE, IN 47715

SAMPLE IDENTIFICATION

LIEAC DEMONSTRATION

PROJ. NO. 91001

CHAIN OF CUSTODY RECORD \#5353

DAILY COMPOSITE $12 / 07 / 93$

LAB-GENERATED COMPOSITE

ARSENIC (As) $=12.1 \mathrm{ug} / \mathrm{g}$ DRY COAL BASIS

FLUORINE $(F)=48.3 \mathrm{ug} / \mathrm{g}$ DRY COAL BASIS

CHLORINE $=0.04 \%$ DRY BASIS

GRINDABILITY MOISTURE $=2.23 \%$

DATE REPORTED: $12 / 30 / 93$

\begin{tabular}{|c|c|c|c|c|c|c|}
\hline & $\%$ Moisture & $\%$ Ash & $\%$ Volatile & $\%$ Fixed Carbon & B.T.U.AB. & $\%$ Suifur \\
\hline As Rec'd. & 12.49 & 9.79 & $\mathbf{X X X X}$ & XXX8 & 11390 & 2.24 \\
\hline Dry Basis & ---- & 11.19 & $\mathbf{X X X X}$ & $\mathbf{X X X X}$ & 13016 & 2.56 \\
\hline M-A-Free & & & & & 14656 & \\
\hline
\end{tabular}

FREE SWELLING INDEX : XXXX

$\begin{array}{lccc}\text { ASH FUSION TEMPERATURES } & \text { (DEG F) } & \text { REDUCING } & \text { OXIDIZING } \\ \text { INITIAL } & & 2165 & 2525 \\ \text { SOFTENING } & 2275 & 2535 \\ \text { HEMISPHERICAL } & 2385 & 2545 \\ \text { FINAL } & 2460 & 2555\end{array}$

HARDGROVE GRINDABILITY INDEXI , :50

NOTE: $X X X X$ INDICATES ANALYSIS WAS NOT PERFORMED 
Lab. No

62322

$12 / 08 / 93$

Date Rec'd

$12 / 07 / 93$

Date Sampled

CLIEnT

Sampled By$$
\text { The }
$$

ICF KAISER EYGINEERIYG

4 GATBWAY CEKTER

PITTSBURGH, PA 15222-1207

ATTY.: MR. JIM HERVOL

\author{
SAMPLE ID \\ LIFAC DEMONSTRATION \\ PROJ. HO. 91001 \\ CHAIN OF CUSTODY RECORD $\$ 5353$ \\ DAILY COMPOSITE $12 / 07 / 93$ \\ LAB-GEHERATED COMPOSITE
}

DATE REPORTED : $12 / 30 / 93$

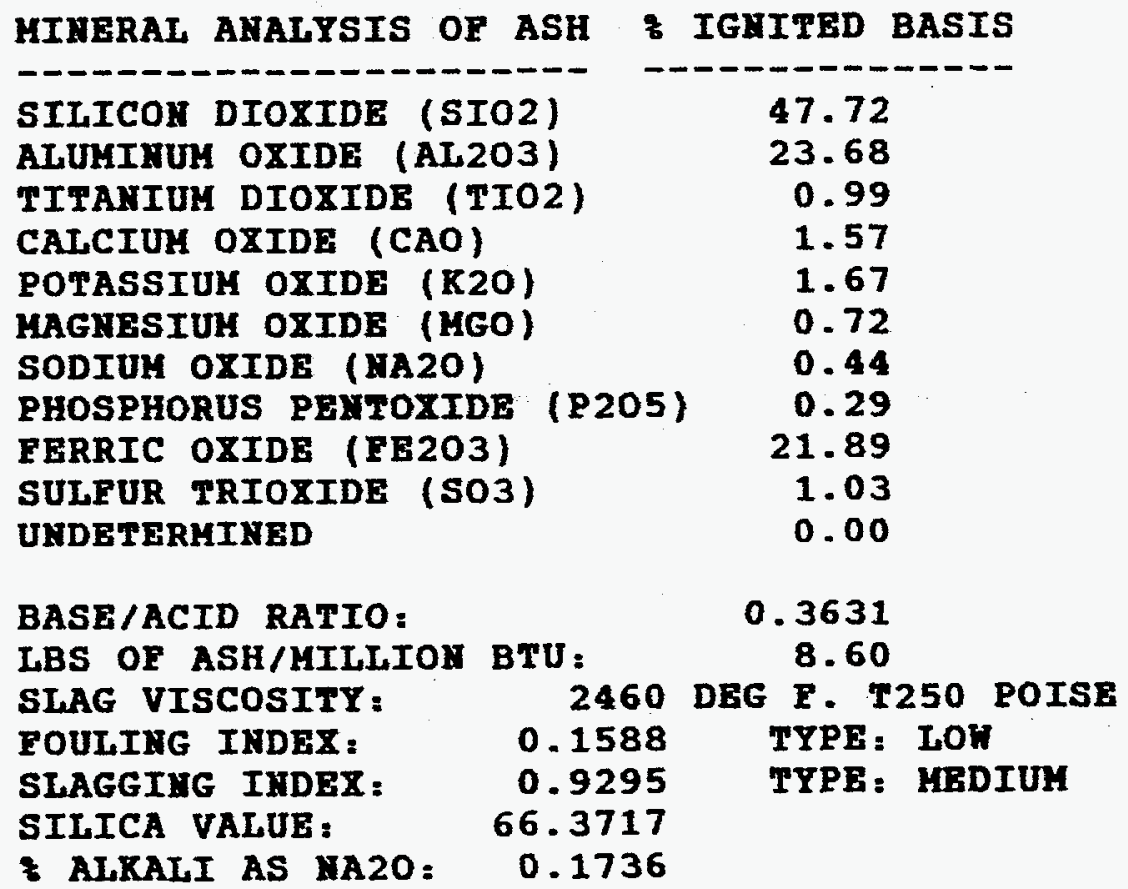

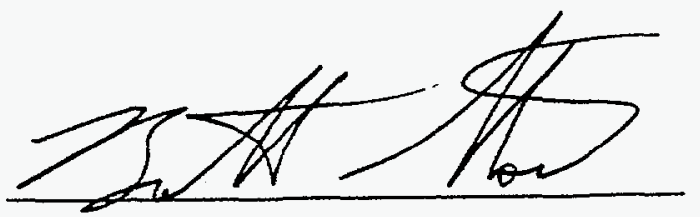


Lab. No.

62273

Date Rec'd

$$
12 / 09 / 93
$$

Date Sampled

$$
12 / 08 / 93
$$

Sampled By

$$
\text { CLIENT }
$$

ICF KAISER ENGINEERING

4 GATEWAY CENTER

PITTSBURGH, PA 15222-1207

ATTN: MR. JIM HERVOL

SAMPLE IDENTIFICATION

STACK TEST

\#1

IIFAC DEMONSTRATION

DATE REPORTED: $\quad 12 / 20 / 93$

\begin{tabular}{lccccc}
\hline & \% Moisture & $\%$ Ash & \% Volatile & \% Fixed Carbon & B.T.U./LB. \\
\hline As Rec'd. & 12.53 & 9.71 & 34.59 & 43.17 & 11431 \\
\hline $\begin{array}{l}\text { Dry Basis } \\
\text { M-A-Free }\end{array}$ & 11.10 & 39.55 & 49.35 & 13069 \\
\hline
\end{tabular}


Lab. No.

62273

Date Rec'd

$12 / 09 / 93$

Date Sampled

$12 / 08 / 93$

Sampled By

\section{CLIEIT}

ICF KAISER ENGINEERIMG

4 GATEHAY CBHTER

PITTSBURGH, PA 15222-1207

ATIN.: HR. JIM HRRVOL
STANDARD LABORATORIES,INC.

1530 \%. CULIEX AVBIUE EVARSVILLE, II 47715

SAMPLE ID

STACK TEST

$\because 1$

LIFAC DEHOYSTRATIOY

DATE REPORTED : $12 / 21 / 93$

ULTIMATE AHALYSIS OR COAL DRY BASIS

ASH

HYDROGEX

CARBON

HITROGEY

SULPUR

OXTGEX
11.10

4.95

73.10

1.48

2.56

6.81

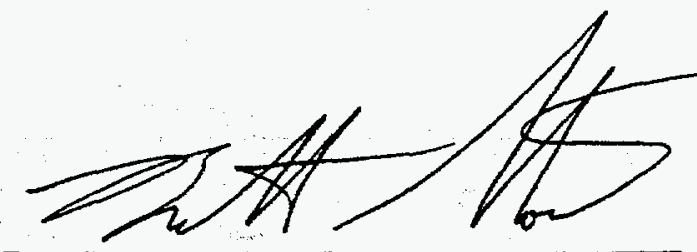


Lab, No

62274

Date Rec'd

$12 / 09 / 93$

Date Sampled

$12 / 08 / 93$

Sampled By

\section{CLIBNT}

ICF KAISER ENGINEERTNG

4 GATEWAY CENTER

PITTSBURGH , PA 15222-1207

ATTY: MR. JIM HERVOL

\section{0 \&. CULLEH AVEXUE \\ EVANSVILLE. IN 47715}

SAMPLE IDENTIFICATION

STACK TEST

$\because 2$

LIFAC DEMONSTRATION

DATE REPORTED: $\quad 12 / 20 / 93$

\begin{tabular}{|c|c|c|c|c|c|c|}
\hline & $\%$ Moisture & $\%$ Ash & $\%$ Volatile & $\%$ Fixed Carbon & B.T.U./LB. & $\%$ Sulfur \\
\hline As Rec'd. & 12.76 & 9.75 & 34.36 & 43.13 & 11373 & 2.18 \\
\hline Dry Basis & ---- & 11.18 & 39.38 & 49.44 & 13037 & 2.50 \\
\hline M-A-Free & & & & & 14678 & \\
\hline
\end{tabular}

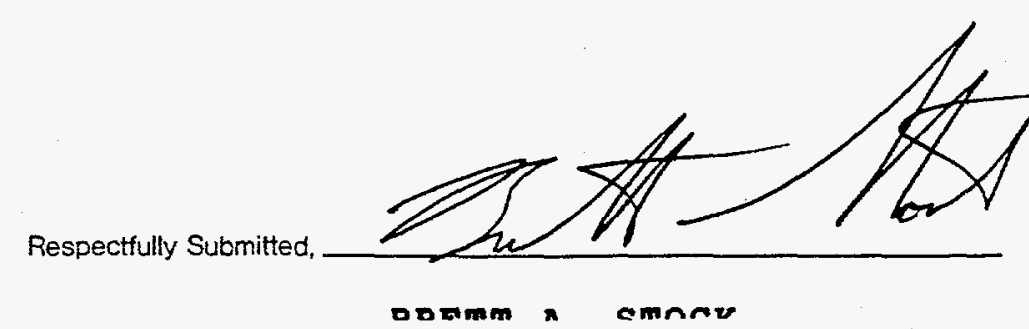




Lab. No. $\frac{62274}{12 / 09 / 93}$
Date Rec'd $\frac{12 / 08 / 93}{\text { Date Sampled }}$
Sampled By CLIENT

1530 A. CULIEA AVEAUE

EVARSVILLE, II 47715

SAMPLE ID:

STACK TEST

ICE RAISER EWGINEERIXG

4 GATENAY CBMTER

PITTSBURGH, PA 15222-1207

$* 2$

IIFAC DEMOUSTRATION

ATTY.: HR. JIM HERVOL

DATE REPORTED: $12 / 21 / 93$

\begin{tabular}{lr} 
ULTIMATE ANALYSIS OF COAL & DRY BASIS \\
\hline ASH & 11.18 \\
HYDROGEX & 4.88 \\
CARBON & 73.30 \\
MITROGEX & 1.46 \\
SULFUR & 2.50 \\
OXYGEX & 6.68
\end{tabular}

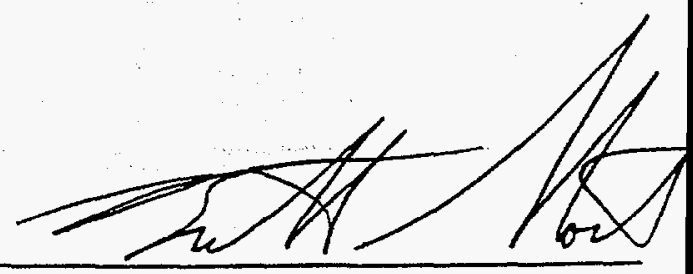


Lab. No.

62275

Date Rec'd

$12 / 09 / 93$

Date Sampled

$12 / 08 / 93$

Sampled By

\section{CLIENT}

ICE KAISER BNGINEERING

4 GATENAY CENTER

PITTSBURGH, PA 15222-1207

ATTN: MR. JIM HERVOL

\section{N. CULLEN AVENUE \\ EVAMSVILLE, IN 47715}

SAMPLE IDENTIFICATION

STACK TEST

$\$ 3$

LIFAC DEMOKSTRATION

DATE REPORTED: $12 / 20 / 93$

\begin{tabular}{lllllrr}
\hline & \% Moisture & $\%$ Ash & $\%$ Volatile & \% Fixed Carbon & B.T.U./LB. \\
\hline As Rec'd. & 12.96 & 9.34 & 33.62 & 44.08 & 11440 & 2.10 \\
\hline $\begin{array}{l}\text { Dry Basis } \\
\text { M-A-Free }\end{array}$ & 10.73 & 38.63 & 50.64 & 13143 & 2.41 \\
\hline
\end{tabular}

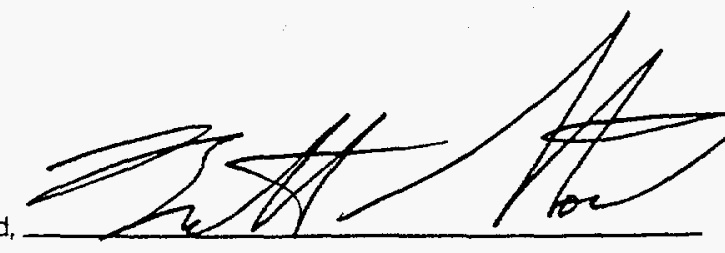




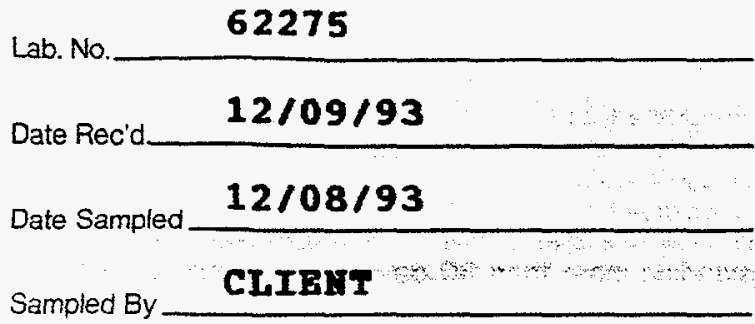

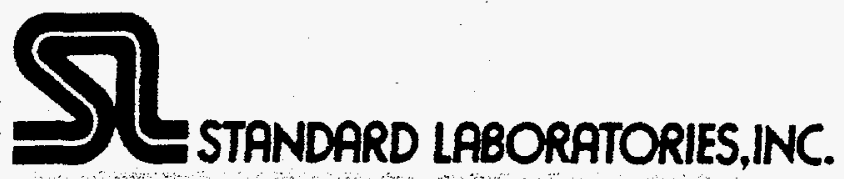

ICF KAISER ENGIHEERIYG

4 GATBHAY CENTER

PITTSBURGH, PA 15222-1207

STACK TEST

$\$ 3$

1530 H. CULLEY AVEMUE

EVAKSVILLE, IN 47715

SAMPLE ID:

LIFAC DEMONSTRATION

DATE REPORTED :

$12 / 21 / 93$

\begin{tabular}{lc} 
ULTIMATE AHALYSIS OF COAI & DRY BASTS \\
\hline ASH & 10.73 \\
HYDROGEX & 4.88 \\
CARBON & 74.02 \\
UITROGEX & 1.48 \\
SULFUR & 2.41 \\
OXYGEX & 6.48
\end{tabular}

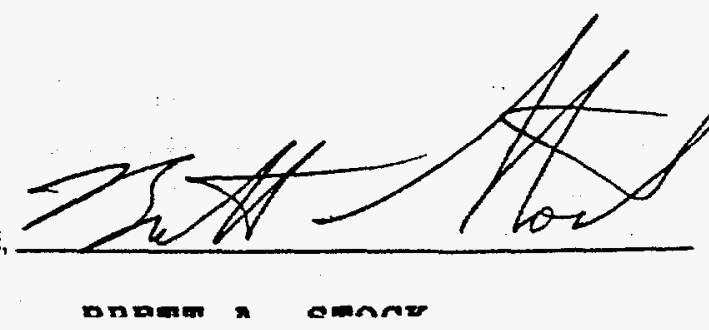


Lab. No.

62276

Date Rec'd

$12 / 09 / 93$

Date Sampled

$12 / 08 / 93$

Sampled By

\section{CIIENT}

ICF KAISER BNGINEERING

4 GATEWAY CENTER

PITTSBURGH, PA 15222-1207

ATTH: MR. JIM HERVOL

SAMPLE IDENTIFICATION

STACK TEST

\#4

LIEAC DEMONSTRATION

DATE REPORTED: $12 / 20 / 93$

\begin{tabular}{llcccc}
\hline & \% Moisture & \% Ash & \% Volatile & \% Fixed Carbon & B.T.U./LB. \\
\hline As Rec'd. & 12.97 & 9.33 & 33.06 & 44.64 & 11423 \\
\hline $\begin{array}{l}\text { Dry Basis } \\
\text { M-A-Free }\end{array}$ & 10.72 & 37.99 & 51.29 & 13125 & 2.03 \\
\hline
\end{tabular}




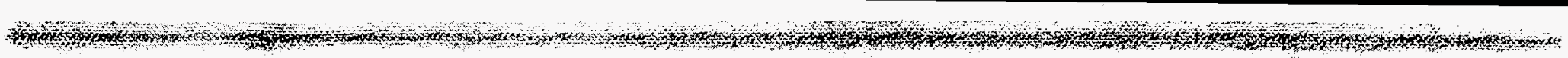

Lab. No 62276

Date Rec'd $12 / 09 / 93$

Date Sampled $12 / 08 / 93$

1530 . A. CULIFA AVERUE EVRISVTIIE, II 47715

Sampled By CIIEII

SAMPLE ID:

STACK TEST

ICF KAISER EHGIHEERIHG

*4

4 GATEWAY CEHTER

PITTSBURGH, PA 15222-1207

LIFAC DEHONSTRATION

ATTI.: MR. JIY HERVOL

\begin{tabular}{lr} 
ULTIMATE AMALYSIS OF COAL & DRY BASIS \\
\hline ASH & 10.72 \\
HYDROGEX & 4.85 \\
CARBOH & 74.40 \\
HITROGEX & 1.51 \\
SULFUR & 2.33 \\
OXYGEY & 6.19
\end{tabular}

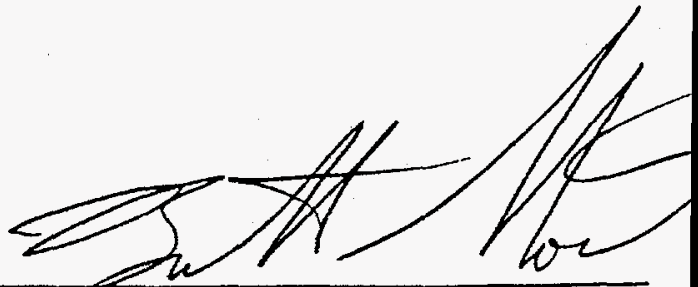


Lab. No.

62323

Date Rec'd

$12 / 09 / 93$

Date Sampled

$12 / 08 / 93$

Sampled By

$$
\text { CLIENT }
$$

ICF KAISER ENGINEERING

4 GATEWAY CENTER

PITTSBURGH, PA 15222-1207

ATTN : MR. JIM HERVOL

SAMPLE IDENTIFICATION

LIFAC DEMONSTRATION

PROJ. NO. 91001

CHAIN OF CUSTODY RECORD \#5355

DAILY COMPOSITE $12 / 08 / 93$

LAB-GENERATED COMPOSITE

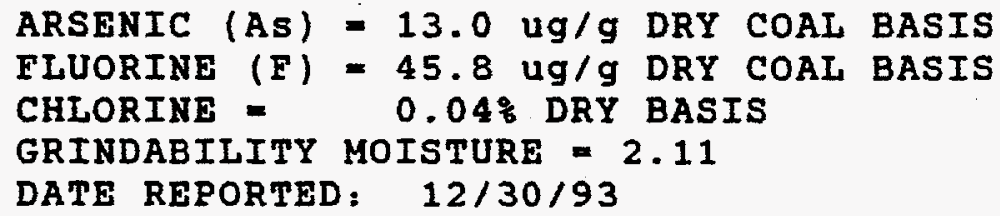

\begin{tabular}{lccccc}
\hline & $\%$ Moisture & $\%$ Ash & \% Volatile & \% Fixed Carbon & B.T.U./LB. \\
\hline As Rec'd, & 12.81 & 9.53 & $\mathbf{X X X X}$ & $\mathbf{X X X X}$ & 11417 \\
\hline $\begin{array}{l}\text { Dry Basis } \\
\text { M-A-Free }\end{array}$ & 10.93 & $\mathbf{X X X X}$ & $\mathbf{X X X X}$ & 13094 \\
\hline
\end{tabular}

FREE SWELLING INDEX : XXXX

$\begin{array}{lccc}\text { ASH FUSION TEMPERATURES } & \text { (DEG E) } & \text { REDUCING } & \text { OXIDIZING } \\ \text { INITIAL } & & 2175 & 2550 \\ \text { SOFTENING } & 2310 & 2575 \\ \text { HEMISPHERICAL } & 2410 & 2600 \\ \text { FINAL } & & 2490 & 2620\end{array}$

HARDGROVE GRINDABILITY INDEX（，:51

NOTE : XXXX INDICATES ANALYSIS WAS NOT PERFORMED 
Lab. No

62323

$12 / 09 / 93$

Date Rec'd

$$
12 / 08 / 93
$$

Date Sampled

CLIEIT

Sampled By

ICF KAISER ENGIHEERING

4 GATBNAY CEXTER

PITTSBURGH, PA 15222-1207

ATTY.: MR. JIM HERVOL
STANDARD LABORATORIES,INC.

1530 \%. CULLEA AVBYUE

BVAMSVILLE, IU 47715
SAMPLEILFAC DEMONSTRATIOY

PROJ. NO. 91001

CHAIX OF CUSTODY RECORD $\$ 5355$

DAILY COHPOSITE $12 / 08 / 93$

LAB-GEUERATED COHPOSITE

DATE REPORTED : $12 / 30 / 93$

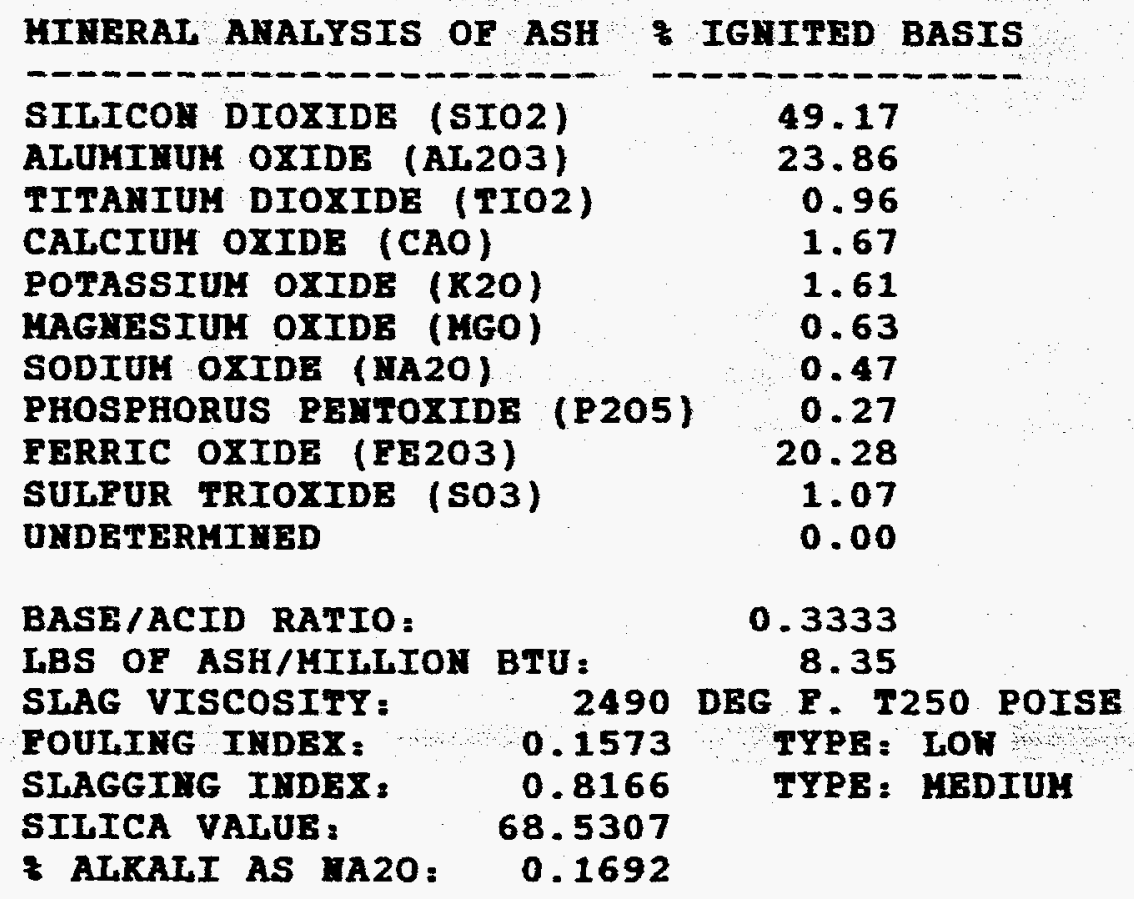


Lab. No. 73653

Date Rec'd. $05 / 18 / 94$

Date Sampled $95 / 17 / 94$

Sampled By CLIENT
$1530 \mathrm{~N}$. CULIEN AVENUE EVANSVILIE, IN $\$ 7715$

ICF KAISER ENGINEERING

4 GATEWAY CENTER

PITTSBURGH, PA 15222-1207

ATTN: MR. JIM HERVOL

SAMPLE IDENTIFICATION

COAL $\triangle A M P L E$ FROM STA. \#1

DATE REPORTED: $\quad 06 / 02 / 94$

\begin{tabular}{|c|c|c|c|c|c|c|}
\hline & $\%$ Moisture & $\%$ Ash & $\%$ Volatile & $\%$ Fixed Carbon & B.T.U./LB. & $\%$ Sulfur \\
\hline As Rec'd. & 13.66 & 8.94 & 34.55 & 43.75 & 11368 & 2.24 \\
\hline Dry Basis & $\ldots-\cdots$ & 9.32 & 40.01 & $50: 67$ & $\therefore=13167$ & -2.59 \\
\hline M-A-Free & & & & & 14519 & \\
\hline
\end{tabular}

Method

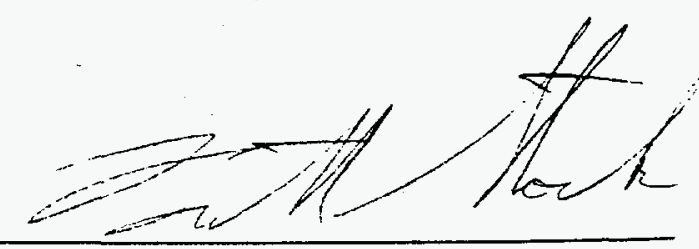




\begin{tabular}{ll} 
Date Rec'd. No. $\frac{73658}{05 / 18 / 94}$ \\
Date Sampled $\frac{05 / 17 / 94}{\text { CLIENT }}$ \\
\hline
\end{tabular}

ICF RAISER ENGINEERING

4 GATEHAY CENTER

PITTSBURGH, PA 15222-1207

ATTN: MR. JIM HERVOL

DATE REPORTED : $\quad 06 / 02 / 94$

\begin{tabular}{lc} 
ULTIMATE ANALYSIS OF COAL & DRY BASIS \\
\hline ASH & 9.32 \\
HYDROGEN & 5.11 \\
CARBON & 74.32 \\
NITROGEN & 1.53 \\
SULFUR & 2.59 \\
OXYGEN & 7.13
\end{tabular}

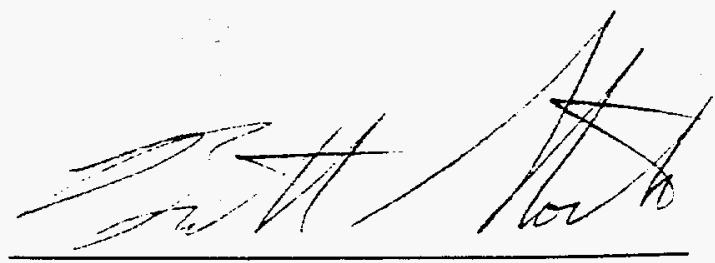


Lab. No. 73659

Date Rec'd $05 / 18 / 94$

Date Sampled

$05 / 17 / 94$

Sampled By CLIENT

ICE KAISER ENGINEERING

4 GATEWAY CENTER

PITTSBURGH, PA 15222-1207

ATTN: MR. JIM HERVOL

\section{$1530 \mathrm{~N}$. CULLEN AVENUE \\ EVANSVILLE, IN 47715}

SAMPLE IDENTIFICATION

COAL. SAMPLE FROM STA. \#2

DATE REPORTED: $\quad 06 / 02 / 94$

\begin{tabular}{|c|c|c|c|c|c|c|}
\hline & $\%$ Moisture & $\%$ Ash & \% Volatile & $\%$ Fixed Carbon & B.T.U./LB. & $\%$ Sulfur \\
\hline As Rec'd. & 13.70 & 8.22 & 34.71 & 43.37 & 11343 & 2.15 \\
\hline Dry Basis & ---- & 9.53 & 40.22 & 50.25 & 13143 & $\dot{2} .49$ \\
\hline
\end{tabular}

M-A-Free 


\begin{tabular}{ll} 
Lab. No. $\frac{73659}{05 / 18 / 94}$ \\
Date Rec'd $\frac{05 / 17 / 94}{\text { Date Sampled }}$ \\
Sampled By CLIENT \\
\hline
\end{tabular}

1539 N. CULLEN AVENUE EVANSVILLE, IN 47715

SAMPLEID: COL SAMPLE FROM STA. \$2

ICF RAISER ENGINEERING

4 GATEWAY CENTER

PITTSBURGH, PA 15222-1207

ATTX: MR. JIM HERVOL

DATE REPORTED: $\quad 06 / 02 / 94$

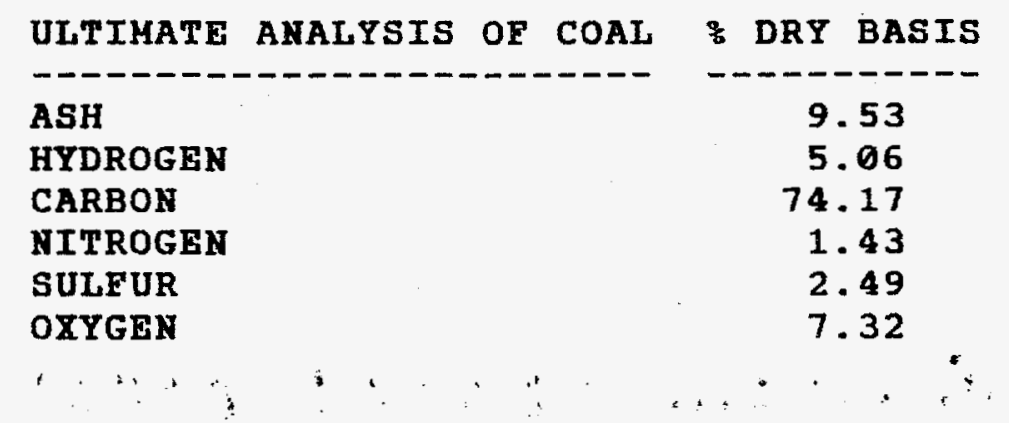

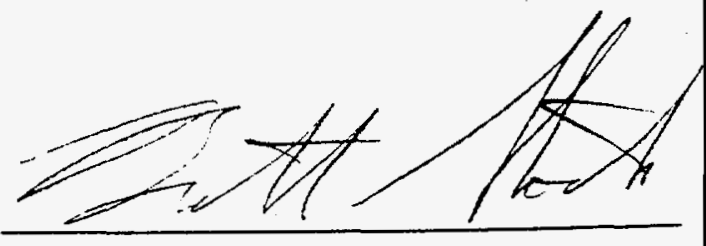


Lab. No. 73660

Date Rec'd $05 / 18 / 94$

Date Sampled

$05 / 17 / 94$

Sampled By

CLIENT

ICE KAISER ENGINEERING

4 GATEWAY CENTER

PITTSBURGH, PA $15222-1207$

ATTN: MR. JIM HERVOL

SAMPLE IDENTIFICATION

COAL SAMPLE FROM STA. \#3

DATE REPORTED: $\quad 06 / 02 / 94$

\begin{tabular}{|c|c|c|c|c|c|c|}
\hline & $\%$ Moisture & $\%$ Ash & $\%$ Volatile & $\%$ Fixed Carbon & B.T.U./LB. & $\%$ Sulfur \\
\hline As Rec'd. & 13.79 & 8.11 & 34.72 & 43.38 & 11432 & 2.07 \\
\hline Dry Basis & $\ldots$ & 9.41 & 49.27 & 50.32 & 13261 & 2.40 \\
\hline M-A-Free & & & & & 14638 & \\
\hline
\end{tabular}




\begin{tabular}{|c|c|}
\hline & 73660 \\
\hline Date Recid & $05 / 18 / 94$ \\
\hline Date Sampled & $05 / 17 / 94$ \\
\hline & CLIENT \\
\hline
\end{tabular}

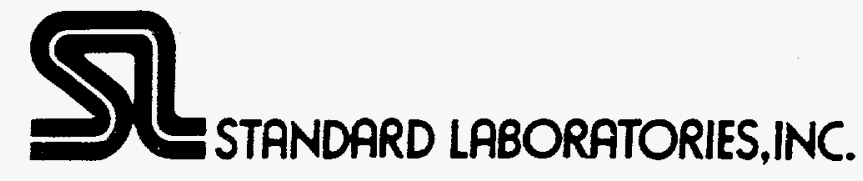

1530 3. CULLEN AVENUE

EVANSVILLE, IN 47715

SAMPLE ID:

COAL SAMPLE FROM STA. \#3

ICE KAISER ENGINEERING

4 GATEWAY CENTER

PITTSBURGH, PA 15222-1207

ATTN: MR. JIH HERVOL

DATE REPORTED : $\quad 96 / 02 / 94$

$\begin{array}{lc}\text { ULTIMATE ANALYSIS OF COAL } & \text { O DRY BASIS } \\ \text { ASH } & 9.41 \\ \text { HYDROGEN } & 5.03 \\ \text { CARBON } & 74.07 \\ \text { NITROGEN } & 1.52 \\ \text { SULFUR } & 2.40 \\ \text { OXYGEN } & 7.57\end{array}$


Lab. No. 73661

Date Rec'd. $05 / 18 / 94$

Date Sampled $05 / 17 / 94$

Sampled By CLIENT

ICF KAISER ENGINEERING

4 GATEWAY CENTER

PITTSBURGH, PA 15222-1207

ATTN : MR. JIM HERVOL

$1530 \mathrm{~N}$. CULLEN AVENUE

EVANSVILLE, IN 47715

SAMPLE IDENTIFICATION

COMPOSTTE OF STA. \#1,2,\&3

CHLORINE $=\angle 0.01 \%$ DRY COAL BASIS

FLUORINE $=43.6$ UG/G DRY COAL BASIS

ARSENIC $=7.84$ UG/G DRY COAL BASIS

DATE REPORTED: $06 / 10 / 94$

\begin{tabular}{|c|c|c|c|c|c|c|}
\hline & $\%$ Moisture & $\%$ Ash & $\%$ Volatile & $\%$ Fixed Carbon & B.T.U./LB. & $\%$ Sulfur \\
\hline As Rec'd. & 13.46 & 8.27 & $\mathrm{XXXX}$ & $\mathbf{X X X X}$ & 11487 & 2.12 \\
\hline Dry Basis & $-\cdots--$ & $\therefore 9.56$ & $\mathbf{X X X X}$ & $\mathbf{X X X X}$ & 13274 & 2.45 \\
\hline M-A-Free & & & & & 14677 & \\
\hline
\end{tabular}

FREE SWELLING INDEX : XXXX

$\begin{array}{lccc}\text { ASH FUSION TEMPERATURES } & \text { (DEG F) } & \text { REDUCING } & \text { OXIDIZING } \\ \text { INITIAL } & & 2080 & 2495 \\ \text { SOFTENING } & & 2200 & 2515 \\ \text { HEMISPHERICAL } & 2305 & 2540 \\ \text { FINAL } & & 2375 & 2570\end{array}$

HARDGROVE GRINDABILITY INDEX : 50

e $3.22 \%$ MOISTURE

NOTE: XXXX INDICATES ANALYSIS WAS NOT PERFORMED
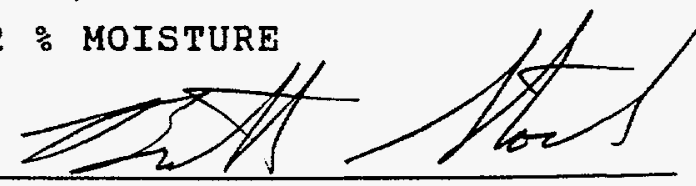


Lab. No. $\frac{73661}{05 / 18 / 94}$
Date Rec'd.
Date Sampled $\frac{05 / 17 / 94}{\text { CLIENT }}$
Sampled By $\quad$ CLIEN

SAMPLE D:

COMPOSITE OF STA. $\$ 1,2,83$

ICF KAISER BYGIYEERIYG

DATE REPORTED: $06 / 10 / 94$

4 GATENAY CBNTER

PITTSBURGH, PA 15222-1207

ATTH: MR. IIH HERVOL

HIMERAL ANALYSTS OP ASH

\& IGNITED BASIS

SIIICON DIOXIDE (STO2)

39.48

ALUMIXUY OXIDE (AL 203)

24.31

TITAKIUM DIOXIDE (TIO2)

0.99

CALCIUM OXIDE (CAO)

3. 10

POTASSIUH OXIDE (K2O)

1.70

MAGIESIUM OXIDE (KGO)

0.59

SODIUH OXIDE (NA2O)

0.45

PHOSPHORUS PEXTOXIDE (P205)

Q. 42

FERRIC OXIDE (FE203)

SULFUR TRIOXIDE (SO3)

26.30

URDETERYIKED

2.66

0.00

BASE/ACID RATIO:

LBS OF ASH/MILLION BTU

0.4962

SLAG VISCOSITY:

7.20

FOULING INDEX :

2310

DEG $F$. T250 POISE

SLAGGIMG INDEX:

0.2252

TYPE : MEDIUH

SILICA VALUE :

1.2157

TYPE : MEDIUH

* ALKaLI AS NA2O:

56.8304

0.1516

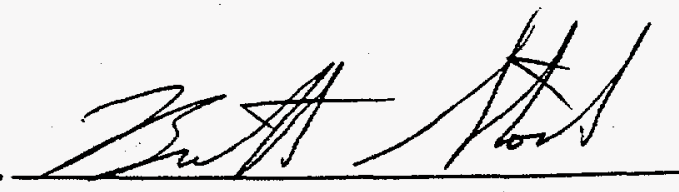


Lab. No

78152

Date Rec'd

$$
08 / 18 / 94
$$

Date Sampled

Sampled By

$$
\text { CIIENT }
$$

ICF KAISER ENGINEERING

4 GATEWAY CENTER

PITTSBURGH, PA 15222-1207

ATTN: MR. JIM HERVOL

\section{$1530 N$. CULLEN AVENUE \\ EVANSVILLE, IN 47715}

SAMPLE IDENTIFICATION

ST \# 1

STACK TEST 1

$08 / 16 / 94$

DATE REPORTED: $09 / 08 / 94$

\begin{tabular}{lccccc}
\hline \hline & $\%$ Moisture & $\%$ Ash & \% Volatile & \% Fixed Carbon & B.T.U./LB. \\
\hline As Recd. & 13.07 & 8.91 & 35.75 & 42.27 & 11429 \\
\hline Dry Basis & -0.25 & 41.12 & 48.63 & 2.29 & 13147 \\
\hline M-A-Free & & 10.25 & 14648 \\
\hline
\end{tabular}

Method

41.12

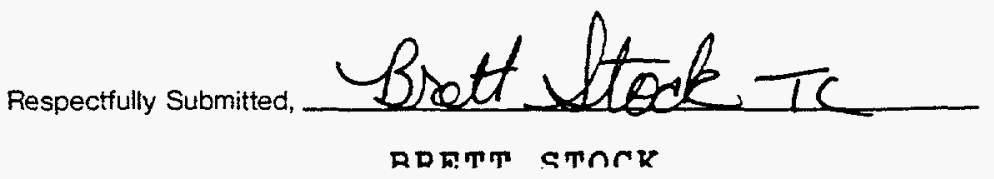


Lab. No.

78152

Date Rec'd $08 / 18 / 94$

Date Sampled

Sampled By ctrane
1530 . CULTEN AVBNUE EVAMSVILLE, IH 47715

SAMPLE 1D:

$S T+1$

STACK TEST 1

$08 / 16 / 94$

ICF RAISER BNGINBERING

DATE REPORTED: $09 / 08 / 94$

\begin{tabular}{lr} 
ULTIMATE ANALYSIS OF COAL & DRY BASIS \\
\hline ASH & 10.25 \\
HYDROGEN & 5.17 \\
CARBOH & 73.21 \\
HITROGEX & 1.67 \\
SULFUR & 2.64 \\
OXYGEY & 7.06
\end{tabular}


Lab. No.

78153

Date Rec'd

$08 / 18 / 94$

Date Sampled

Sampled By

\section{CLIENT}

ICE KAISER ENGINEERING

4 GATEWAY CENTER

PITTSBURGH, PA 15222-1207

ATTN : MR. JIM HERVOL

SAMPLE IDENTIFICATION

$S T \# 2$

STACK TEST \#2

$08 / 16 / 94$

DATE REPORTED: $09 / 08 / 94$
1530 N. CULLEN AVENUE

EVANSVILLE, IN 47715 


\section{3}

Lab. No

$08 / 18 / 94$

Date Rec'd

$$
----
$$

Date Sampled

\section{CIIENT}

Sampled By

ICF RAISER BHGIHEERING

4 GATEHAY CENTER

PITTSBURGH, PA 15222-1507

ATTY: MR. JIM HERVOL

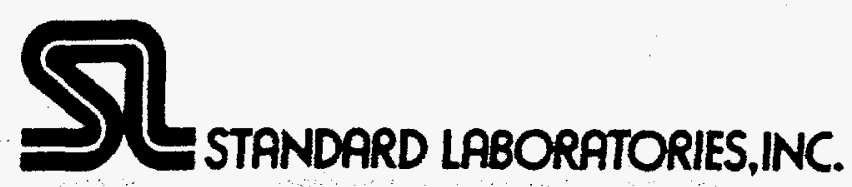

\section{A. CULLEX AVEMUE}

BVAUSVILIE, IM 47715

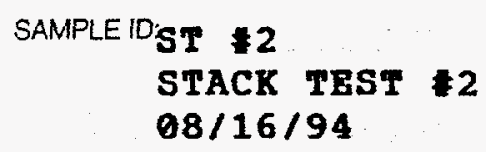

DATE REPORTED :

\begin{tabular}{lr} 
ULTIHATE ANALYSIS OF COAL & DRY BASIS \\
\hline ASH & 9.61 \\
HYDROGEX & 5.14 \\
CARBOK & 73.74 \\
RITROGEY & 1.65 \\
SULFUR & 2.72 \\
OXYGEX & 7.14
\end{tabular}


Lab. No.

78154

Date Rec'd

$08 / 18 / 94$

Date Sampled

\section{CLIENT}

Sampled By

ICF KAISER ENGINEERTNG

4 GATEWAY CENTER

PITTSBURGH, PA 15222-1207

ATTN : MR. JIM HERVOL

SAMPLE IDENTIFICATION

ST $\# 3$

STACK TEST \#3

$08 / 16 / 94$

DATE REPORTED: $\quad 09 / 08 / 94$

\begin{tabular}{|c|c|c|c|c|c|c|}
\hline & $\%$ Moisture & $\%$ Ash & $\%$ Volatile & $\%$ Fixed Carbon & B.T.U./LB. & $\%$ Sulfur \\
\hline As Rec'd. & 13.01 & 8.61 & 36.33 & 42.05 & 11500 & 2.36 \\
\hline Dry Basis & ----- & 9.90 & 41.76 & 48.34 & 13220 & 2.72 \\
\hline M-A-Free & & & & & 14673 & \\
\hline
\end{tabular}

Method

\section{N. CULLEN AVENUE \\ EVANSVILLE, IN 47715}


Lab. No

78154

Date Rec'd

$08 / 18 / 94$

Date Sampled 1530 A 2 CUKTEI AVBRUE

Sampled By CLIBIT BVAMSVILIE, IR 47715

SAMPLE ID:

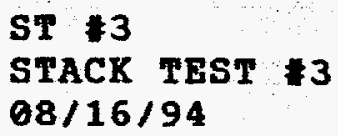

DATE REPORTED: $09 / 08 / 94$

\begin{tabular}{lc} 
ULTIKATE ANALYSTS OF COAL & DRY BASIS \\
\hline ASH & 9.90 \\
HYDROGEH & 5.14 \\
CARBON & 73.42 \\
HITROGEX & 1.65 \\
SULFUR & 2.72 \\
OXYGEX & 7.17
\end{tabular}


Lab. No.

78155

\section{$08 / 18 / 94$}

Date Rec'd.

Date Sampled

Sampled By

\section{CLIENT}

ICE KAISER ENGINEERING

4 GATEWAY CENTER

PITTSBURGH, PA 15222-1207

ATTN: MR. JIM HERVOL

\section{N. CULLEN AVENUE \\ EVANSVILLE, IN 47715}

SAMPLE IDENTIFICATION

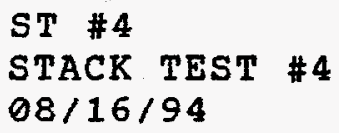

DATE REPORTED: $09 / 08 / 94$

\begin{tabular}{|c|c|c|c|c|c|c|}
\hline & $\%$ Moisture & $\%$ Ash & $\%$ Volatile & $\%$ Fixed Carbon & B.T.U./LB. & $\%$ Sulfur \\
\hline As Rec'd. & 12.98 & 8.60 & 36.27 & 42.15 & 11546 & 2.33 \\
\hline Dry Basis & ---- & 9.88 & 41.68 & 48.44 & 13269 & 2.68 \\
\hline M-A-Free & & & & & 14723 & \\
\hline
\end{tabular}


78155

Lab. No.

$08 / 18 / 94$

Date Rec'd

Date Sampled

Sampled By

\title{
CIIEXT
}

\author{
SAMPLE ID: $S T$ :4 \\ STACK TEST $\div 4$ \\ $08 / 16 / 94$
}

ICF KAISER BNGIXEERING

4 GATEWAY CENTER

PITTSBURGH, PA 15222-1507

ATTK : MR. JIM HERVOL.

DATE REPORTED:

\begin{tabular}{lc} 
ULTIMATE ANALYSIS OF COAL & DRY BASIS \\
\hline ASH & 9.88 \\
HYDROGEN & 5.19 \\
CARBON & 73.53 \\
HITROGEX & 1.68 \\
SULFUR & 2.68 \\
OXYGEN & 7.04
\end{tabular}

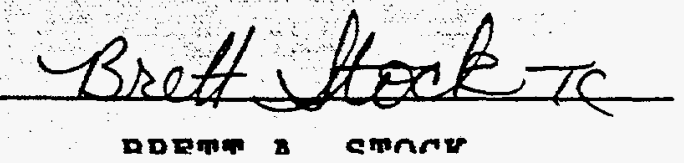


APPENDIX II

LIMESTONE ANALYSIS 
CLIENT I.D........ LIFAC DEACHSTRATICH

OATE SAMPLED......: 12/07/93

IILE SAMPLED......: :

WCRK DESCRIPTICN...: LMAESTCNE DAILY SAMPLED
LABCRATCRY I.D...: 932413-CCO1

DATE RECEIVED. $\because . .: 12 / 14 / 93$

TIME RECEIYED..... 12:00

REMAXS........... CIIETT SAMPLED

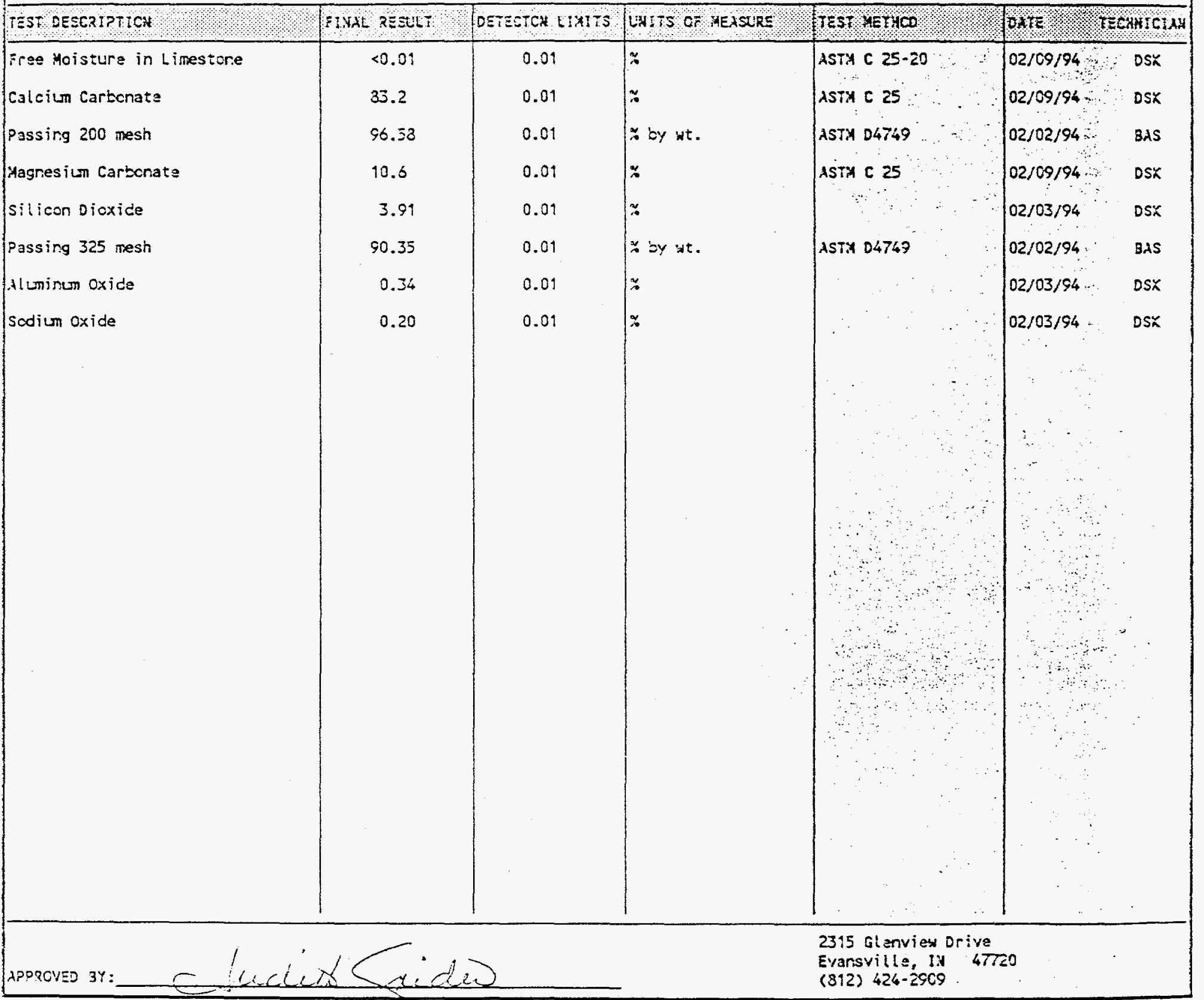


QUALITY ASSURAXCE REPORT

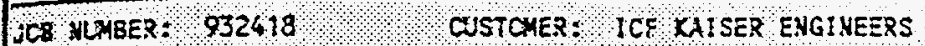

ATTY. $1 \mathrm{HA}$ HERVO

\begin{tabular}{|c|c|c|c|c|c|c|c|c|c|c|}
\hline \multicolumn{4}{|c|}{ AHALYSIS } & \multicolumn{2}{|c|}{ CUPLICATES } & \multicolumn{2}{|c|}{ REFERENCE STANDARDS } & \multicolumn{3}{|c|}{ MATRIX SPIKES } \\
\hline $\begin{array}{l}\text { ANALYSSIS } \\
\text { TYPE }\end{array}$ & $\begin{array}{l}\text { ANALYSIS } \\
\text { SUB-TYPE }\end{array}$ & $\begin{array}{c}\text { ANALYSIS } \\
1.0 .\end{array}$ & $\begin{array}{l}\text { ANALYYZED } \\
\text { VALUE (A) }\end{array}$ & $\begin{array}{l}\text { DUPLICATE } \\
\text { VALUE (B) }\end{array}$ & $\mid \begin{array}{l}\text { RPD or } \\
(|A-B|)\end{array}$ & $\begin{array}{l}\text { TRUE } \\
\text { VALLEE }\end{array}$ & $\begin{array}{l}\text { PERCENT } \\
\text { RECOVERY }\end{array}$ & $\begin{array}{c}\text { CRIGINAL } \\
\text { VALUE }\end{array}$ & $\begin{array}{l}\text { SPIKE } \\
\text { ACDED }\end{array}$ & $\begin{array}{l}\text { PERCENT } \\
\text { RECOVERY }\end{array}$ \\
\hline
\end{tabular}

PARAMETER : Sil R ICan Dhoxide DETECTIOH LIMTOO.01\%

DATE/TIYE ANALYZZO:002/03/94 12:30

C. BNTCI ULMBER 940725

\begin{tabular}{l|l|l|}
\hline BLANK & Reagent & Blank
\end{tabular}

STANDARD Analytical ICP4 1:100

DUPLICATE

Analytical $932277-1$

0.6
1.1
29.5

YETHCO REFEREXCE :

TECHMICTAN:DSX

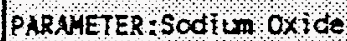

DETEETIOH LIMHTO 0.01

(

METHCO REFERENCE,

\begin{tabular}{|l|l|l|l}
\hline BLANK & Reagent & Blank & 1.8
\end{tabular}

BLANK

STANDARD

STAKDARD

SPIXE

SPIXE

DUPLICATE

DUPLICATE

Reagent

Blank

Analytical ICP 2

Analytical ICP 2

Analytical $940168-2$

Analytical

Analytical

Analytical

$940171-1$

$940168-1$

Analytical $940171-1$

\begin{tabular}{c|c}
1.8 & \\
1.5 & \\
9.8 & \\
9.9 & \\
41.6 & \\
39.4 & \\
609 & 609 \\
30.8 & 31.0 \\
0.34 & 0.34
\end{tabular}

0


0
0.65
0

10.0
10.0

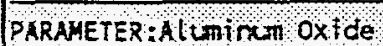
DETECTICN LIMIT:0.01

DATE/TIME ANALYZZED :02/03/94, 11:00 METHOO REFERENCE

\begin{tabular}{|l|l|l|}
\hline 1.0 & 110 & \\
\hline
\end{tabular}

\begin{tabular}{|l|l|}
\hline & \\
\hline
\end{tabular}

OC BATCH YUNBER - 940726 IECHAICTAN:DSK

\begin{tabular}{|l|l|l|l}
\hline BLANK & Reagent & Blank & 0.12
\end{tabular}

STANDARO

STANDARD

DUPLICATE

\begin{tabular}{|l|l|} 
Reagent & Blank \\
Analytical & APG 7878 \\
Analyt ical & ERA 9947 \\
Analyt ical & $932277-1$
\end{tabular}

0.12
0.06
0.16
2.89

(1)

98

30.4
30.8

\begin{tabular}{|l|r|}
\hline & \\
10.0 & 112 \\
10.0 & 26 \\
& \\
OCATC & \\
\hline BLMBER :940727
\end{tabular} IECHHICTAHODSK

PARAMETER :Passing 200 mesh DETECTION LIMIT $=0.01 \%$ UNITS : $\mathrm{S}$ bY $\mathrm{wt}$.

DATE/TIUE ANALYZED:02/02/94\%? METHCO REFERENCE ?

CC BATCH YLABER: 940863 TECHNICHAN:BAS

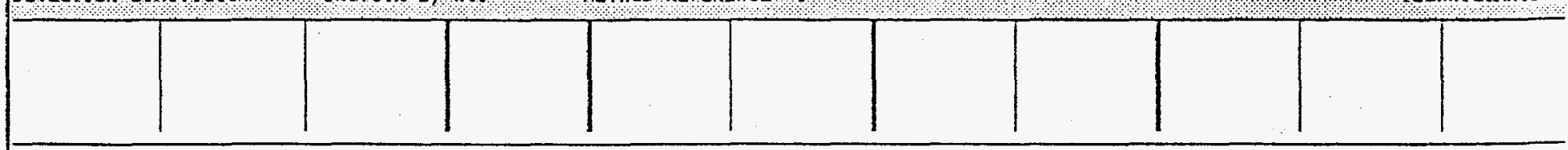

APPROVED BY

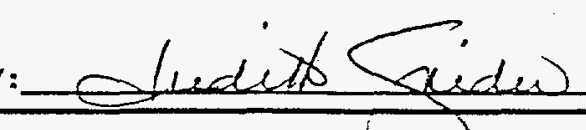

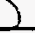

2315 Glenview Drive

Evansville, in 47720 (812) $424-2909$

PAGE: 1

$M C=$ Not Calculable Due To Lower Than The Detection Limit

Quality Control Acceptance Criteria:
Blanks .............
Reference Standards
Analyzed Value $=/<$ Detection Limit
$100+1-10$ Percent Recovery
Spikes ............... $100+1-25$ Percent Recovery

Hote: Data Reported In QA Report May Be Lower Than Value On Sampla Data Page Due To Dilution of Sample Into Analytical Range 
